NBSIR 80-2134

\title{
Fire Performance of Selected Residential Floor Constructions Under Room Burnout Conditions
}

J. B. Fang

Center for Fire Research

National Engineering Laboratory

National Bureau of Standards

U.S. Department of Commerce

Washington, DC 20234

December 1980

Interim Report

Prepared for:

Division of Energy, Building Technology and Standards nffice of Policy Development and Research

j. Department of Housing and Urban Development

100 ishington, DC 20410

.456

80-2134

1980

c. 2 

FIRE PERFORMANCE OF SELECTED RESIDENTIAL FLOOR CONSTRUCTIONS UNDER ROOM BURNOUT CONDITIONS
FEB 271981

not.acc-arc

Q $=100$

U.

1980

C. 2

\section{J. B. Fang}

Center for Fire Research

National Engineering Laboratory

National Bureau of Standards

U.S. Department of Commerce

Washington, DC 20234

December 1980

Interim Report

Prepared for:

Division of Energy, Building Technology and Standards

Office of Policy Development and Research

U.S. Department of Housing and Urban Development

Washington, DC 20410

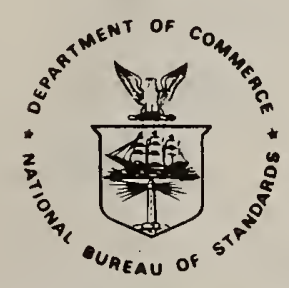

U.S. DEPARTMENT OF COMMERCE, Philip M. Klutznick, Secretary Jordan J. Baruch, Assistant Secretary for Productivity, Technology, and Innovation NATIONAL BUREAU OF STANDARDS, Ernest Ambler, Director 

LIST OF TABLES

LIST OF FIGURES

Abstract

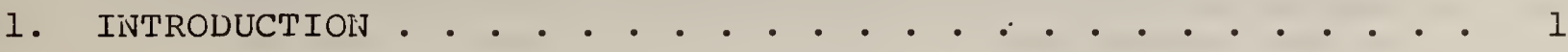

2. EXPERIMENTAL DETAILS • . . . . . . . . . . . . . . . 3

2.1 Test Room . . . . . . . . . . . . . . . . . . 3

2.2 Vall Materials . . . . . . . . . . . . . . . . 3

2.3 Interior Furnishings . . . . . . . . . . . . . . . 3

2.4 Test Assemblies . . . . . . . . . . . . . . . . . . 4

2.5 Structural Loading . . . . . . . . . . . . . . 9

3. TEST MEASUREMENTS • • • . . . . . . . . . . . . . . . . 9

3.1 Temperature . . . . . . . . . . . . . . . . . 9

3.2 Floor Deflection . . . . . . . . . . . . . . . . 10

3.3 Static Pressure at Wall . . . . . . . . . . . . . 11

3.4 Heat Flux . . . . . . . . . . . . . . . . . . . 11

3.5 Air Velocity at Doorway . . . . . . . . . . . . . . 11

3.6 Optical Density of Smoke . . . . . • . • . . . . . 12

3.7 Gas Concentrations . . . . . . . . . . . . . . . 12

3.8 Data Acquisition . . . . . . . . . . . . . . 12

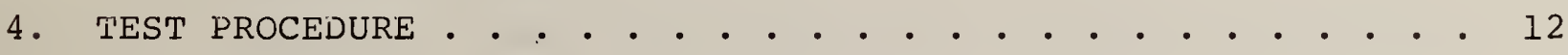

4.1 Fire T'est . . . . . . . . . . . . . . . . . . 12

4. 2 Fire Resistance Criteria . . . . . . . . . . . . . . 13

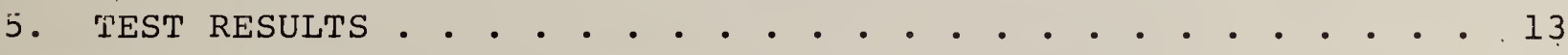

5.1 Room Fire Exposure . . . . . . . . . . . . . . . . 13

5.2 Performance of Test Assemblies . . . . . . . . . . . 16

6. DISCUSSION . . . . . . . . . . . . . . . . . . . 18

7. SUIMARY • • • . . . . . . . . . . . . . . . . 23

8. ACKNOWLEDGEMENTS • • • • • • • • • • • • • • • • • • 23

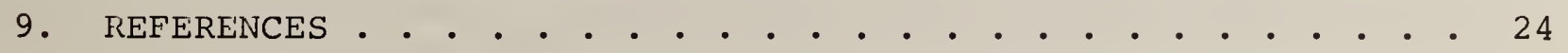

AFPENDIX A - Maximum Design Load Calculations

APPENDIX B - Log of ilests Based on Visual Observations

TABLES $1-9$

FIGURES 1 - 26 
Table 1 -- Initial weights of furnishings and wall linings and total available heat of all combustibles used for fire tests. . . . 25

Table 2 -- Descriptions of combustible contents . . . . . . . . . . . 26

Table 3 -- Descriptions of test assemblies and loading conditions . . . 27

Table 4 -- Initial weights and potential heat of combustible materials in test assemblies... . . . . . . . . . . . . . . . 28

Table 5 -- Ambient conditions and fire growth events during the tests . . 29

Table 6 -- Summary of various measurements during fully developed stage . 30

Table 7 -- Incident heat fluxes measured at various locations . . . . . 31

Table 8 -- Optical density of smoke and gas. concentration of outflowing gases. . . . . . . . . . . . . . . . . . . . 32

Table 9 -- Summary of the fire resistance period of floor assemblies in room burnout tests. . . . . . . . . . . . . . . . . 33 
Figure 1 -- Plan View of the Test Room Showing Locations of Furniture and Wall Linings... . . . . . . . . . . . . . . 34

Figure 2 -- Floor-Ceiling Assembly Construction and Instrumentation Layout for Test l. . . . . . . . . . . . . . . 36

Figure 3 -- Floor-Ceiling Assembly Construction and Instrumentation Layout for Test 2. . . . . . . . . . . . . . . . 37

Figure 4 -- Floor-Ceiling Assembly Construction and Instrumentation Layout for Test 3... . . . . . . . . . . 38

Figure 5 -- Floor-Ceiling Assembly Construction and Instrumentation Layout for Test 4. . . . . . . . . . . . . . . 39

Figure 6 -- Floor-Ceiling Assembly Construction and Instrumentation Layout for Test 5... . . . . . . . . . . . . . 40

Figure 7 -- Floor Plan Showing Layout of Gypsum Board Ceiling for Tests 5 to 7 . . . . . . . . . . . . . . . . 41

Figure 8 -- Details of Wood Truss Construction for Test 6. . . . . . . 42

Figure 9 -- Floor-Ceiling Assembly Construction and Instrumentation Layout for Test 6. . . . . . . . . . . . . . . 43

Figure 10 -- Floor-Ceiling Assembly Construction and Instrumentation Layout for Test 7. . . . . . . . . . . . . . . . 44

Figure 11 -- Layout of Steel Blocks Distributed Uniformly Over the Top of Floor Assembly for Test 7 . . . . . . . . . . . . . 45

Figure 12 -- Plan View of the Test Room Showing Instrumentation Layout. . 47

Figure 13 -- Instrumentation Layout at the Doorway Opening. . . . . . . 48

Figure 14 -- Instrumentation Layout-View of West (Back) Wall Showing Wall Thermocouples and Heat Flux Meters. . . . . . . . . 49

Figure 15 -- Instrumentation Layout-View of South Plywood Wall Showing Wall Thermocouples, Total Heat Flux Meter, and Radiometer. . 50

Figure 16 -- Instrumentation Layout-View of North Plywood Wall Showing Wall Thermocouples . . . . . . . . . . . . . 51

Figure 17 -- Comparison of Average Upper Room Gas Temperature for Tests 1 to 4 and Experimentally Derived Fire Exposure Curve. . . . 52

Figure 18 -- Comparison of Average Upper Room Gas Temperature for Tests 5 to 7 and Experimentally Derived Fire Exposure Curve. . . . 53

Figure 19 -- Floor Deflection Measured at the Center of the Test Assembly . . . . . . . . . . . . . . . . . . 54

Figure 20 -- Floor Deflections at Center and Quarter Points Along the Center Joist at Various Times for Test 2 . . . . . . . 55

Figure 21 -- Time Variations of Average Surface Temperatures on the Unexposed Side of Test Assembly for all Tests Performed. . . 56 
Figure 22 -- Comparison of Surface Temperature of Steel Joist and Plywood Subfloor for Assemblies With and without a Protective Ceiling. . . . . . . . . . . . . 57

Figure 23 -- Relationship Between Floor Deflection and Steel Joist Temperature at Center of Test Assembly. . . . . . . . 58

Figure 24 -- Relationship Between Floor Deflection and Wood Joist Temperature at Center of Test Assembly. . . . . . . . . 59

Figure 25 -- Time Variation of Average Temperature of Steel Joists at Various Locations . . . . . . . . . . . . . . 60

Figure 26 -- Relationship Between Floor Deflection and Temperature of Surrounding Gas and Steel Joist Temperature... . . . . 61 


\section{FIRE PERFORMANCE OF SELECTED RESIDENTIAL FLOOR \\ CONSTRUCTIONS UNDER ROOM BURNOUT CONDITIONS}

\section{Jin Bao Fang}

Abstract

A series of seven large-scale room burnout fire tests was conducted with a set of selected residential floor-ceiling assemblies to provide data on the performance of the assemblies; these will be compared with the results in future tests on the same constructions in a fire endurance furnace. Four wood-frame and three light gage steel-frame, load-bearing assemblies, each measuring $3.7 \times 3.7 \mathrm{~m}$ in size, were exposed from the underside to a fire environment produced from the burning of typical furniture and interior finish materials in a room. The fire resistance periods based on flame-through of floor assembly and structural failure of floor joists varied from 10 to 12 minutes for floors with unprotected wood joists and was 4 minutes or less for floors with unprotected steel joists. The addition of a $13 \mathrm{~mm}$ thick gypsum board ceiling as a protective layer increased the fire resistance time of the steel joisted floor assembly approximately 12 minutes.

Key words: Fire endurance, fire tests, flame through, floors, furniture, interior finishes, joists, room fires, steel, wood.

\section{INTRODUCTION}

The performance of a residential floor-ceiling assembly under fire exposure conditions is of major importance in the confinement of a fire to its room of origin. Safe evacuation of building occupants and successful fire fighting operations are dependent on the structural integrity of the assembly during the fire.

Wood joist framed floor systems have historically been used above residential basement rooms in single family dwellings. In recent housing 
construction techniques, a variety of light-gauge metal joists and preassembled small section wooden trusses have been proposed and used as structural components for floor assemblies. These types of floor framing are claimed to have advantages over conventional wood joists, e.g., lower price, ability to carry greater loads, and availability of various specified lengths. In order to reduce the cost of construction, the floor joists over basements are often not covered on the underside with a fire protective ceiling. A building fire may therefore produce a collapse of the unprotected load-bearing structural elements and spread flames to the next story. Information on the performance of protected and unprotected floof constructions when exposed to actual fires is essential in the design of fire-safe buildings.

The fire resistance of structural systems is commonly evaluated under the fire exposure or elevated temperature conditions specified by the standard ASTM El19 test method [1], and expressed in terms of the time at which the structure collapses, passes flame, or has an excessive temperature rise on the unexposed side. This standard fire exposure curve specified over sixty years ago represents a limiting curve of burnout tests mostly in masonry structures and without full recognition of the effects of ventilation (heat losses through doors and windows). It does not describe the typical fire environment likely to result in room fires involving modern furnishings. However, the majority of regulatory building codes state the fire resistance requirements of floors in terms of the ASTM Ell9 test.

The research effort for the current task of the present floor assembly fire endurance study program sponsored by the office of Policy Development and Research within the U.S. Department of Housing and Urban Development (HUD) at NBS is directed toward providing technical data on the fire performance of selected loaded floor/ceiling assemblies subject to the specified fire environments developed in earlier work [2]. This report describes the experimental results of a series of seven full-scale fire resistance tests involving selected loaded, wood and steel framed residential floors. The fire environments utilized for these tests were produced from the burning of typical furniture and interior finish materials in a full-sized room with an open door. Summary data include the times elapsed to failure of floor joists and to flame-through of the assembly, the time histories of the floor deflections and the average unexposed surface temperature, and other parameters reflecting the fire growth in the room. Structural failure of the floor joists and flame-through of the floor assembly were considered principal criteria since they were related directly to sudden failure of the floor to provide support or safety to the occupants (residents or fire fighters). In single-family residential constructions and in other situations where compartmentation is not a design feature, the time to excessive temperature rise on the unexposed surface of the assembly 
may not be of major significance. However, in this study, excessive surface temperature rise on the fire unexposed side of the floor was also considered as a criterion of fire performance.

\section{EXPERIMENTAL DETAILS}

\subsection{Test Room}

All of the fire resistance tests were performed in a burn room having a $3.3 \times 3.3 \mathrm{~m}(10.7 \times 10.7 \mathrm{ft})$ floor with $2.3 \mathrm{~m}(7.4 \mathrm{ft})$ ceiling height as shown in figure 1. A doorway opening measuring $0.8 \mathrm{~m}$ (30 in) wide by $2.0 \mathrm{~m}$ (80 in) was situated in the middle of one of the room walls to serve as the single source of room ventilation. The basic construction of the burn room was $0.2 \mathrm{~m}$ ( $8 \mathrm{in}$ ) thick standard light weight aggregate-concrete block walls and a concrete floor. The entire test room was built within an air conditioned, large building to control environmental effects.

\subsection{Wall Materials}

For each test, the internal walls of the test room were lined with 4-mm (5/32-in) thick prefinished and printed 3-ply lauan plywood panels. The wall framing consisted of nominal $25 \times 76 \mathrm{~mm}$ ( $1 \times 3$ in) wood furring strips spaced $0.4 \mathrm{~m}$ ( $16 \mathrm{in}$ ) on center and secured to the concrete block walls with $51-\mathrm{mm}$ (2-in) long masonary nails. The plywood panels were applied with long edges parallel to the frame with interior hardened 25-mm (1-in) long paneling nails, $0.2 \mathrm{~m}$ ( $8 \mathrm{in}$ ) on center. The perimeter seams of the paneling walls were covered with $15.9 \times 9.5 \mathrm{~mm}$ prefinished wood shoe molding. A summary of the initial weights of wall materials used for each test is given in table 1.

\subsection{Interior Furnishings}

The household furniture used for each experiment were those commonly found in a recreation room and included a sofa, an upholstered chair and ottoman, an end table, a bookcase, and a coffee table. A description of the materials, size, and nominal weight of these furniture items is presented in table 2. Figure 1 shows the floor plan of the trpically furnished room illustrating the layout of wall linings and geometrical arrangement of domestic furniture similar to those used in test 9 of basement room burnout test series [2]. The loading density of the moveable combustibles used for the series of fire tests was $23 \mathrm{~kg} / \mathrm{m}^{2}\left(4.7 \mathrm{lb} / \mathrm{ft}^{2}\right)$ of floor area, which was the average value for recreation rooms in the basements of single family homes 
in the Washington, D.C. metropolitan area [3]. In addition to the furnishings, old record files were added in sufficient quantities to reach the required fire load density. A total of $4.54 \mathrm{~kg}$ paper was placed atop the coffee table, $1.81 \mathrm{~kg}$ each on the tops of the ottoman and the end table, and the rest (approx. $77 \mathrm{~kg}$ ) on the shelves of the bookcase. An olefin carpet with foam rubber backing was placed on top of a protective layer of $16-\mathrm{mm}(5 / 8-\mathrm{in})$ thick, type $\mathrm{x}$, gypsum wallboard covering the concrete floor.

The initial weights and total available heat of the furnishings and the wall linings used for all of the fire tests performed are given in table 1. The total fire load density ranged from 35.8 to $38.1 \mathrm{~kg} / \mathrm{m}^{2}(7.3$ to 7.8 $\left.1 \mathrm{~b} / \mathrm{ft}^{2}\right)$ with an average of $37.1 \mathrm{~kg} / \mathrm{m}^{2}\left(7.6 \mathrm{lb} / \mathrm{ft}^{2}\right)$ of floor area. An estimate of total heat available from the burning of the interior furnishings and wall linings for each test was made using these weight data and the weight percentages of the component materials utilized for constructing the furniture items based on the information provided in table 2. The heat of combustion values employed for the available energy calculations were $16.7 \mathrm{MJ} / \mathrm{kg}$ for paper, $18.6 \mathrm{MJ} / \mathrm{kg}$ for wood, $46.5 \mathrm{MJ} / \mathrm{kg}$ for olefin fabric and carpet, and 26.5 $\mathrm{MJ} / \mathrm{kg}$ for polyurethane foam. The combustible load had an available energy density ranging from 724 to $782 \mathrm{MJ} / \mathrm{m}^{2}$ with a mean of $753 \mathrm{MJ} / \mathrm{m}^{2}$ of floor area.

\subsection{Test Assemblies}

For each test, a selected floor/ceiling assembly $3.7 \mathrm{~m}$ wide by $3.7 \mathrm{~m}$ long ( 12 x $12 \mathrm{ft}$ ) was built over the top of concrete block walls of the burn room, carried uniformly distributed loads and was subjected to similar fire conditions. The portion of the assembly exposed to the room fire below was $3.2 \times 3.2 \mathrm{~m}(10.5 \times 10.5 \mathrm{ft})$ finished dimensions. The following types of floor constructions were tested for their fire resistance in this research and a description of the structural elements used for the various assemblies and applied loads are given in table 3 .

Assembly 1

The assembly was supported by nominal 51 x $203 \mathrm{~mm}$ ( 2 x 8 in) wood joists placed parallel to the wall containing a doorway opening and spaced $0.41 \mathrm{~m}$ (16 in) on center as illustrated in figure 2, which shows the construction details and instrumentation layout of the floor system. Each joist was kiln dried, construction grade no. 2, eastern spruce. The joists were cut to $3.57 \mathrm{~m}$ long and secured to nominal $51 \mathrm{x} 203 \mathrm{~mm}$ wood rim joists with two 90-mm (3-1/2-in) long l6d common nails at ends of each joist. The rim joists were toenailed to nominal 51 x $203 \mathrm{~mm}$ wood sill plates resting on the tops 
of concrete block walls using $16 \mathrm{~d}$ common nails spaced $0.41 \mathrm{~m}$ on center. Each sill plate was positioned with its edge flush with the inner wall surface and fastened with washers and nuts to 3 anchor bolts embedded in the concrete which filled the core of top course of blocks in the concrete block wall.

A single layer of $16-\mathrm{mm}$ (5/8-in) thick, underlayment grade Douglas fir plywood subfloor was laid perpendicular to the joists with end joints staggered $0.81 \mathrm{~m}$ (32 in) and secured to the joists with $41 \mathrm{~mm}$ ( $1-5 / 8 \mathrm{in}$ ) long type $\mathrm{S} 12$ screws spaced $0.15 \mathrm{~m}$ ( $6 \mathrm{in}$ ) on center at panel edges and $0.31 \mathrm{~m}$ (12 in) on center at intermediate supports. An olefin carpet with foam rubber backing measuring $3.67-\mathrm{m}$ long by $3.67-\mathrm{m}$ wide was fixed to the plywood deck with $16-\mathrm{mm}$ ( $5 / 8 \mathrm{in})$ long carpet tacks spaced $0.20 \mathrm{~m}$ on center along its perimeter.

$\underline{\text { Assembly } 2}$

The floor framing used C-shaped, galvanized steel joists, $184 \mathrm{~mm}$ (7-l/4 in) deep with a $45-\mathrm{mm}(1-3 / 4-i n)$ flange, a $14 \mathrm{~mm}$ (9/16 in) lip and a $1.26-\mathrm{mm}$ (18 gauge) thickness. The joists were spaced $0.61 \mathrm{~m}$ (24 in) on center beginning with one joist positioned along the centerline of the room width, except that two end joists had a spacing of $0.41 \mathrm{~m}$ from the adjacent joists to accommodate a $3.25-\mathrm{m}$ span. Figure 3 shows the details of the floor construction and the arrangement of instrumentation. Each joist was cut $3.57 \mathrm{~m}$ (140.5 in) long and secured to nominal $51 \times 203 \mathrm{~mm}(2 \times 8 \mathrm{in}$ ) wood rim joist with two $8 \mathrm{~d} 64-\mathrm{mm}(2-1 / 2-i n)$ long common nails driven through steel end clips. A horizontal galvanized steel strap, 51-mm wide by $1.61-\mathrm{mm}$ (16 gauge) thick, was installed at the mid-span in accordance with structural design information supplied by the manufacturer for steel joists. The strap attached to the bottom flange of each hoist and its ends fastened to the concrete block walls. The rim joists were secured to nominal 51 x $203 \mathrm{~mm}$ wood sill plates bolted to the top course of the block walls, with $16 \mathrm{~d} 89-\mathrm{mm}$ (3-1/2-in) long common nails spaced $0.41 \mathrm{~m}$ on center.

The plywood used to form the subfloor was $16 \mathrm{~mm}$ (5/8 in) thick, Douglas fir, supplied in $1.22 \mathrm{~m}$ by $2.44 \mathrm{~m}(4 \mathrm{x} 8 \mathrm{ft})$ sheets with long edges tongue and grooved, and marked APA Group 1 interior with exterior glue in conformance with U.S. Product Standard, PS 1-74. The plywood was installed with its long dimensions perpendicular to the joists and its end joints staggered and fastened to the framing with 48-mm (1-7/8-in) long type sl2 screws spaced $0.15 \mathrm{~m}$ on center at the panel edges and $0.30 \mathrm{~m}$ on center at the intermediate supports. The $3.67 \mathrm{~m}$ by $3.67 \mathrm{~m}$ olefin carpet with a foam rubber backing was secured at its perimeter with $16-\mathrm{mm}(5 / 8-i n)$ long carpet tacks spaced approximately $0.2 \mathrm{~m}$ on center. 
The floor system was supported by C-shaped galvanized steel joists, $184 \mathrm{~mm}(7-1 / 4 \mathrm{in})$ deep with a 45-mm (1-3/4-in) flange, and a $1.26-\mathrm{mm}$ (18 gauge) thickness. The joists were spaced $0.81 \mathrm{~m} \mathrm{(32} \mathrm{in)} \mathrm{on} \mathrm{centers,} \mathrm{and} \mathrm{were}$ fastened to nominal 51 × $203 \mathrm{~mm}$ ( 2 × 8 in) wood rim joists with $8 d$ common nails driven through steel end clips as shown in figure 4. The rim joists were secured to nominal $51 \times 203 \mathrm{~mm}$ wood sill plates anchored to the top of the concrete block walls of the test room.

A single layer of 19-mm (3/4-in) thick, underlayment grade, tongue and groove, Douglas fir plywood was installed perpendicular to the joists with end joists staggered $0.81 \mathrm{~m}$ (32 in). The plywood was secured to the joists with type S12 by $48 \mathrm{~mm}$ (1-7/8 in) long screws spaced $0.15 \mathrm{~m}$ on center along the edges and $0.30 \mathrm{~m}$ on center along the intermediate joists. A piece of olefin carpet with foam rubber backing was installed over the plywood deck.

$\underline{\text { Assembly } 4}$

The test assembly was constructed in a manner similar to Assembly 1 , except that nominal 51 x $203 \mathrm{~mm}$ ( 2 x 8 in) wood joists were spaced $0.61 \mathrm{~m}$ (24 in) on center starting with a floor joist positioned along the horizontal centerline of the room width, the subfloor was $18 \mathrm{~mm}(23 / 32 \mathrm{in})$ thick, underlayment grade, Douglas fir plywood with long edges tongue and groove, and the solid 51 x $203 \mathrm{~mm}$ bridging of the joists was installed along the mid-span. The construction details of this floor system is shown in figure 5. The wood joists used were southern pine, construction grade no. 2 , medium grain.

\section{Assembly 5}

The assembly consisted mainly of C-shaped galvanized steel joists, 184 $\mathrm{mm}$ (7-1/4 in) deep, and $1.26 \mathrm{~mm}$ (18 gauge) thick, spaced $0.61 \mathrm{~m}$ (24 in) on center, a 18-mm (23/32-in) thick plywood subfloor, an olefin carpet with foam rubber backing and a protective layer of 12.7-mm (1/2-in) thick gypsum board ceiling as illustrated in figures 6 and 7 . Each joist was $3.57 \mathrm{~m} \mathrm{(140.5} \mathrm{in)}$ long and fastened at both ends using 8d common nails driven through galvanized steel end clips, to nominal 51 x $203 \mathrm{~mm}(2 \times 8 \mathrm{in}$ ) wood rim headers. The rim headers were secured to sill plates made from the sections of nominal $51 \times 203$ $\mathrm{mm}$ ( $2 \mathrm{x} 8 \mathrm{in}$ ), construction grade no. 2, southern pine joists and anchored to the top course of concrete block walls, with $16 \mathrm{~d}$ nails spaced $0.41 \mathrm{~m}$ ( 16 in) on center. A horizontal galvanized steel strap $51 \mathrm{~mm}$ wide by $1.3 \mathrm{~mm}$ ( $18 \mathrm{gauge}$ ) thick, was installed along the mid-span, in accordance with the structural design manual furnished by the manufacturer for steel joists. 
A layer of 18-mm (23/32-in) thick underlayment grade, Douglas fir plywood subfloor was installed perpendicular to the joists with end joints staggered $0.81 \mathrm{~m}$ (32 in) between adjacent rows. The plywood was supplied in 1.22 by $2.44 \mathrm{~m}$ ( 4 x $8 \mathrm{ft})$ sheet with long edges tongued and grooved and marked APA group 1 , interior with exterior glue. The subfloor was secured perpendicular to the joists with $48-\mathrm{mm}$ (1-7/8-in) long type $\mathrm{s} 12$ screws spaced $0.15 \mathrm{~m}$ on center at the panel edges and $0.30 \mathrm{~m}$ on center at the intermediate supports. All pockets formed by the rim headers, plywood subfloor, and concrete block walls were filled with $89-\mathrm{mm}(3-1 / 2-i n)$ thick, Rll, kraft paper faced fiber glass insulation. The plywood deck was covered with olefin carpet with foam rubber backing.

The ceiling of the assembly was a single layer of $13-\mathrm{mm}(1 / 2-$ in) thick regular gypsum board installed with the long dimension perpendicular to the joists and attached to each joist with type sl2 25-mm il-in) long bugle head screws spaced at $0.15 \mathrm{~m}$ on center along the perimeter of the board and $0.30 \mathrm{~m}$ on center in the field. All joints and exposed screw heads were taped and covered with joint compound, and the ceiling perimeter seams were finished with wood trim. The ceiling was painted with two coats of white interior flat latex paint.

$\underline{\text { Assembly } 6}$

The structural members used to support the floor-ceiling assembly were $305 \mathrm{~mm}$ (12 in) deep by $89 \mathrm{~mm}$ (3-1/2 in) wide by $3.56 \mathrm{~m} \mathrm{(140} \mathrm{in)} \mathrm{long} \mathrm{wood}$ trusses with nominal 51 by $102 \mathrm{~mm}$ ( 2 x 4 in) wood chords and webs. All wood components had $38 \times 90 \mathrm{~mm}(1-1 / 2$ by $3-1 / 2$ in) cross-section and were kiln dried, southern pine lumber with construction grade no. 2 for top and bottom chords and no. 3 for web members. Flat metal connector plates fabricated from $0.11-\mathrm{mm}$ (20 gauge) thick galvanized steel with $8.28-\mathrm{mm}(0.326-$ in) long teeth were used to secure the web members to the chords. Two plates were applied with the teeth imbedded in the wood members to both sides of the truss at each joint. The details of the wood trusses, which were factory built hy a structural components and systems producer, are shown in figure 8 . The trusses were spaced $0.61 \mathrm{~m}(24 \mathrm{in})$ on center starting with one truss located at the centerline of the test assembly, except that two end trusses had $0.41 \mathrm{~m}$ ( 16 in) spacing from the adjoining trusses to adapt to tile existing span length, and secured to each nominal $51 \times 305 \mathrm{~mm}$ ( $2 \times 12$ in) wood rim joist with three 76.2-mm (3-in) long lod common nails. The rim joists were toenailed with 89-mm (3-1/2-in) long l6d common nails spaced $0.41 \mathrm{~m}$ on center to nominal 51 x $203 \mathrm{~mm}(2 \times 8 \mathrm{in})$ wood sill plates resting on the tops of concrete block walls. In accordance with recommended practice, a nominal $51 \times 152 \mathrm{~mm}(2 \mathrm{x}$ 6 in) by $3.45-m(136-i n)$ long wood bridging was installed at approximately 
mid-span and fastened with three $76 \mathrm{~mm}$ long lod nails to the west vertical web member in the center of each truss.

A single layer of 18-mm (23/32-in) thick, underlayment grade, Douglas fir plywood with long edges tongued and grooved, was laid perpendicular to the trusses with end joints staggered $0.81 \mathrm{~m}$ with adjacent rows of plywood and fastened to the trusses using $51-\mathrm{mm}$ long $6 \mathrm{~d}$ common nails spaced $0.15 \mathrm{~m}$ on center at panel ends and $0.25 \mathrm{~m}$ on center at intermediate supports. The pockets formed by the rim joists, plywood underlayment and the block walls were filled with $89-\mathrm{mm}$ (3-1/2-in) thick, Rll kraft paper-faced fiber glass insulation. An olefin carpet with foam rubber backing was installed atop the plywood subfloor.

The ceiling was $13-\mathrm{mm}(1 / 2-i n)$ thick, regular gypsum wallboard placed below the trusses with the long dimension at right angles to the framing. Each piece of gypsum board was attached to the bottom chords of the trusses with 25-mm ( $1-i n)$ long 512 bugle head screws spaced at $0.15 \mathrm{~m}$ ( 6 in) on center along the perimeter of the board and $0.30 \mathrm{~m}$ on center in the field. All nail heads and joints were taped and covered with joint compound, and the ceiling was painted with two coats of white interior flat latex paint. The intersections between the ceiling and the plywood paneling walls were finished with wood trim. The construction details of the completed test assembly is shown in figure 9.

\section{$\underline{\text { Assembly } 7}$}

The floor framing consisted of nominal 51 x $203 \mathrm{~mm}$ ( $2 \times 8$ in) kiln dried, construction grade no. 2, southern pine joists spaced at $0.61 \mathrm{~m}(24 \mathrm{in}$ ) on center, with the exception of a $0.41-m$ (16-in) spacing for the two end joists apart from the adjacent joists. Each joist was cut to $3.57 \mathrm{~m}$ in length and fastened at its ends to nominal 51 x $203 \mathrm{~mm}$ wood rim joist with two 89-mm (3-1/2-in) long l6d common nails. The rim joists were toenailed to nominal $51 \times 203 \mathrm{~mm}$ wood sill plates anchored to the top course of the concrete block walls, with $89 \mathrm{~mm}$ long l6d nails spaced $0.41 \mathrm{~m}$ on center.

The subfloor was a layer of 18 -mm (23/32-in) thick, underlayment grade, APA group 1, interior with exterior glue, Douglas fir plywood with long edges tongued and grooved. The plywood subfloor was nailed to the joists with 64-mm (2-1/2-in) long $8 \mathrm{~d}$ coated common nails spaced $0.15 \mathrm{~m}$ ( $6 \mathrm{in}$ ) on center at end joints and $0.25 \mathrm{~m}$ on center at intermediate supports. Fiber glass insulating blankets, $89 \mathrm{~mm}$ thick, Rll and kraft paper faced, were used to fill the pockets formed by the rim joists, the plywood subfloor, and the top surfaces of the block walls. An olefin carpet flooring was secured to the plywood deck at its 
perimeter with $16-\mathrm{mm}(5 / 8-$ in) long carpet tacks spaced $0.20 \mathrm{~m}$ on center.

The entire floor was protected by a layer of 16-mm (5/8-in) thick, type $x$, gypsum wallboard installed with the long dimension perpendicular to the joists and fastened to the wood framing using 32-mm (1-1/4-in) long type $S$ bugle head screws spaced $0.15 \mathrm{~m}$ on center on the perimeter of the board and $0.30 \mathrm{~m} \mathrm{o.c.} \mathrm{in} \mathrm{the} \mathrm{field.} \mathrm{The} \mathrm{ceiling-wall} \mathrm{seams} \mathrm{were} \mathrm{finished} \mathrm{with} \mathrm{wood}$ trim and the exposed face of the gypsum board ceiling was painted with two coats of white interior flat latex paint. Figure 10 illustrates the details of the floor-ceiling assembly.

The initial weights and the estimated total available heat of the combustible materials used for constructing test assemblies for the series of fire resistance tests performed are listed in. table 4 . A heat of combustion of $18.6 \mathrm{MJ} / \mathrm{kg}$ was employed for wood materials.

\subsection{Structural Loading}

The floor-ceiling assembly used for each test was loaded, prior to the fire test, with steel blocks, each measuring $140 \times 203 \times 152 \mathrm{~mm}(5-1 / 2 \times 8 \times$ $6 \mathrm{in})$ high and weighing $22.7 \mathrm{~kg}(50 \mathrm{lb})$, to provide an approximation to a uniformly distributed load; this developed maximum allowable deflection or bending stresses in the floor joists as contemplated by the design for most of the tests with the exception of tests 1 and 3 . A live load of $195 \mathrm{~kg} / \mathrm{m}^{2}$ (40 psf) was applied to the test assemblies for tests 1 and 3 as shown in table 3, and this loading corresponded to 69 percent and 74 percent of the respective maximum design loads computed based on maximum permissible deflection of floor joists. The calculation used as the basis for the selection of the maximum design load for test 7 is presented in Appendix $A$, and the floor plan showing the layout of steel blocks distributed over the carpet flooring of this assembly is given in figure 11 .

\section{TEST MEASUREMENTS}

\subsection{Temperature}

The room air temperatures were monitored through bare beaded, $0.51 \mathrm{~mm}$ (0.02 in) diameter (no. 24 B \& S gauge), double-cable chromel-alumel thermocouples at 8 stations including seven locations within the test room and one in the doorway opening. This type of thermocouple was made of two thermocouple cables placed side by side and its measuring junction was formed by welding the positive wire (chromel) from one cable together with the negative wire (alumel) from the other one. This procedure was necessary to avoid the 
problem of the electrical breakdown of the insulation in the individual cables at temperatures above $800^{\circ} \mathrm{C}$. A total of 25 thermocouples were arranged at various heights in vertical thermocouple "trees" at the seven stations inside the room as shown in figure 12, and 12 thermocouples positioned in the other station along the vertical centerline of the doorway illustrated in figure 13. The air temperatures in the upper part of the room were also measured with eight commercial metallic-sheathed, mineral-insulated fast-response thermocouples placed 0.61 and $1.22 \mathrm{~m}$ below the floor-ceiling assembly at the midpoint and the quarter points of the room length, as shown in figure 12. These fast-response thermocouples were constructed from chromel-alumel wires with outside diameter of $1.02 \mathrm{~mm}(0.04 \mathrm{in})$ and the measuring junctions contained within capped $6.4 \mathrm{~mm}$ ( $0.25 \mathrm{in}$ ) outside diameter stainless steel tubes having $0.9 \mathrm{~mm}(0.036 \mathrm{in})$ wall thickness and insulated with magnesium oxide.

The surface temperatures of the plywood paneling and the concrete block walls were determined at 16 stations with the thermocouple beads attached on the exposed and unexposed surfaces at selected places. One location was at the front wall for indicating the involvement of combustible linings in fires, as shown in figure 13; eight were distributed over the back wall in the vicinity of the ignition source on the sofa, shown in figure 14; three stations each were situated at the left and the right plywood paneling walls, as illustrated in figures 15 and 16.

The temperatures on the unexposed side of the test assembly were measured using nine bare beaded, 0.51-mm wire diameter, chromel-alumel thermocouples attached to the top surface of carpet flooring and tightly covered with ceramic fiber pads, $152 \mathrm{~mm}$ square by $13 \mathrm{~mm}$ thick. Figures 2 to 6,9 , and 10 show the locations of these thermocouples along with three additional thermocouples beneath the pads used to measure the temperatures at the points which appeared to be hottest during the test. Surface temperatures were also taken with the bare beaded, double-cable thermocouples within the test assembly. Eight thermocouples were installed in both top and bottom flanges of each selected floor joist, four on the unexposed surface of plywood subfloor and one thermocouple placed on the fire exposed face of the ceiling at the center of the room for the test assemblies with a gypsum board ceiling, also shown in these figures.

\subsection{Floor Deflection}

The deflection of the test assembly during the test was measured with nickel steel cables attached to the midpoint or the quarter points at the top side of each selected joist, and by means of small pulleys, connected to 
linear displacement potentiometers mounted on one wall of the test building. A total of 6 check points for each test structure were employed to provide the relative movement of the floor surface as shown in figures 2 to 6 , 9, and 10 .

\subsection{Static Pressure at Wall}

The levels of static pressure developed within the fire room were continuously measured using 64-mm (1/4-in) outside diameter steel pipes extending through the left wall (south wall) and into the room with their open ends flush with the exposed surface of the plywood paneling wall. Two locations used for these pressure measurements included one situated in the plane $0.3 \mathrm{~m}$ from the front block wall at $0.10,0.30,0.61,1.22,1.70$, and $2.13 \mathrm{~m}$ below the ceiling and the other one at the mid-width of the paneling wall, $0.10 \mathrm{~m}$ from the ceiling, as shown in figure 12. The exterior ends of the pipes were connected by copper and polyvinyl chloride tubing to variable reluctance pressure transducers. Used in combination with carrier demodulators, these produced an output of $40 \mathrm{mv}$ per $\mathrm{Pa}$ pressure change.

\subsection{Heat Flux}

The total heat fluxes incident at selected locations were determined using 5 Gardon-foil type, water-cooled heat flux gauges. Two of these gauges were positioned along the vertical centerline of the back wall flush with the exposed surface of plywood paneling, one each in the left plywood wall and at the center of the carpet flooring, facing the ceiling, and one gauge on a stand located $3 \mathrm{~m}$ in front of the doorway with its vertically oriented sensing element viewing the center of the opening, as shown in figures 12,14 and 15 . The irradiance measurements were made with one Gardon-foil type, wide angle, water-cooled radiometer with an air stream to eliminate convective heat transfer, mounted along the centerline of the left plywood wall flush with its exposed face.

\subsection{Air Velocity at Doorway}

The horizontal velocities of the air entering and leaving the fire room through the doorway opening were monitored with 6 bi-directional flow probes in conjunction with variable reluctance differential pressure transducers and carrier demodulators. These probes were installed normal to the plane of the opening along its vertical centerline and located at $0.13,0.48$, $0.84,1.19,1.55$, and $1.91 \mathrm{~m}$ from the top of the doorway, as illustrated in figure 13 . 
Continuous measurements of the optical density of the smoke at various locations were made by determining the attenuation of a collimated light beam passing through the effluent gas and impinging on a photodector. The light sources were auto spot lights energized by a regulated 6-volt D.C. power supply and the receiver units included photodetectors (PIN3DP). The two locations used to monitor smoke concentrations were (1) in the doorway with 5 horizontal measurements at distances of $0.08,0.30,0.53,0.97$, and $1.50 \mathrm{~m}$ from the top of the opening, with a $0.76 \mathrm{~m}$ long path length along the doorway width, as shown in figure 13, and (2) outside the room, with the light beam having a path length of $2.07 \mathrm{~m}$, horizontally underneath the exhaust hood installed above the door opening.

\subsection{Gas Concentrations}

The combustion gas venting from the fire room was sampled at four locations for measuring the concentrations of selected gas species. Three sampling ports were situated in the doorway at distances of $0.08,0.38$, and $0.76 \mathrm{~m}$ down from the doorway top and one in the stack connected to the exhaust hood. Gas samples withdrawn from the stream of combustion products using stainless steel tubing, after passing through cold traps and filtering tubes packed with glass wool, were analyzed for $\mathrm{O}_{2}, \mathrm{CO}_{2}$, and $\mathrm{Co}$ levels. Concentrations of $\mathrm{CO}_{2}$ and $\mathrm{CO}$ were measured by means of non-dispersive infrared gas analyzers and $\mathrm{O}_{2}$ was measured with polarographic type oxygen cells.

\subsection{Data Acquisition}

A total of 136 sensors including the thermocouples and various transducers were automatically read and recorded by a high speed digital data acquisition system. The data were collected on a magnetic tape at a rate of 8 seconds per scan during the entire duration of test, and subsequently transferred to the computer for processing, tabulating, and plotting.

\section{TEST PROCEDURE}

\subsection{Fire Test}

For each test, the test assembly was loaded with steel blocks to the prescribed load density. The application of the uniform load was normally made within a couple of days prior to the fire test. The ignition source used for all the experiments was a section of newspaper weighing $400 \mathrm{~g}$ and placed along the central backrest and seat cushions of the sofa supported by 
a steel frame holder to insure reproducible ignition conditions between tests. The paper was conditioned to equilibrium with room air controlled at a dry-bulb temperature of $23 \pm 3^{\circ} \mathrm{C}$ and a relative humidity of $50 \pm 5$ percent prior to the test. The fire test was started by remotely igniting the newspaper using an electric heating element and a book of paper matches. Visual observations and photographic and video tape records were made of the progress of the room fires, the burning characteristics of the assembly, and flame-through and collapse of the structural elements. The fire was allowed to burn until the structural failure occurred in the test assembly.

\subsection{Fire Resistance Criteria}

The structural failure was considered to have occurred under any one of the following first two conditions:

I(a) The test assembly collapses, no longer sustaining the applied load.

(b) The collapse of test structure can be expected to occur when both total deflection has attained or surpassed $\mathrm{L}^{2} / 800 \mathrm{~d}$, and an hourly deflection rate has equaled or exceeded $L^{2} / 150 d$, in which $L$ is the span between supports of structural element, and $d$ is the distance between the upper and lower extreme fibers of structural component or assembly [4].

2. Flames or hot gases pass through the test assembly to its unexposed face.

3. The average temperature of the unexposed surface of test structure increased more than $139^{\circ} \mathrm{C}$ above its initial temperature or $181^{\circ} \mathrm{C}$ at one point.

\section{TEST RESULTS}

\subsection{Room Fire Exposure}

Logs of visual observations and records inferred from video tapes taken through the doorway of the fire room, and at the unexposed surface along the center joist during the course of the test are given in appendix B. Also, table 5 presents a summary of experimental results on duration of the test, initial room air temperature, time to appearance of visible flames on the newspaper used as the ignition source, time to room flashover based on selfignition of two types of indicator specimens and attainment of a $20 \mathrm{~kW} / \mathrm{m}^{2}$ 
heat flux level at the center of the floor, and times elapsed for flames issuing out of the doorway and for spontaneous ignition of the olefin carpet flaor. In general, all of the tests performed had a similar history of major events observed during the course of room fire growth. Sustained flaming on the ignition newspaper in the middle of the sofa was normally observed at approximately 0.1 to $0.8 \mathrm{~min}$, the sofa was ignited within the next 0.2 to 0.6 min, and the flames from the burning sofa reached the ceiling at 0.6 to 1.3 min after. flame appearance.

The time of appearance of visible flames on the newspaper was utilized as the reference time due to variability of the buildup of flaming on the newspaper. The rear plywood paneling wall adjacent to the middle of the sofa became ignited at times ranging from 1.0 to $1.7 \mathrm{~min}$ and was immediately followed by vertical flame spreading over the wall surface. As the temperature increased, the flames traveled across the ceiling and the hot gas layer descended to approximately two-fifths of the room height, and the flashover indicators and all other combustible materials soon ignited. The flames blended with heavy smoke passing out of the doorway opening usually occurred immediately before or just after flashover.

As shown in table 5, the times from the sustained flaming of the newspaper on the couch to the spontaneous ignition of the flashover indicators varied from approximately 1.5 to $2.5 \mathrm{~min}$ with an average of $1.9 \mathrm{~min}$ for newspaper and 1.5 to $2.5 \mathrm{~min}$ with a mean of $2.0 \mathrm{~min}$ for filter paper. The time at which the heat flux incident at the center of the floor exceeded $20 \mathrm{~kW} / \mathrm{m}^{2}$ was found to range from about 1.4 to $2.4 \mathrm{~min}$ with an average time of $1.8 \mathrm{~min}$, which was in agreement with those taken for self-ignition of flashover indicators. The average values of the time elapsed prior to flames emerging from the doorway and to ignition of the olefin carpet were found to be 1.7 and $2.1 \mathrm{~min}$, respectively.

Table 6 presents the measured results including the maximum upper room gas temperature, the maximum rate of heat released within the fire room and that discharged through the stack, the maximum flow rate of air flowing in and through the doorway opening, the neutral plane height above the floor level, and the maximum static pressure developed within the room at the peak of the fire. The mean temperature of the hot gas in the upper part of the fire room was obtained by averaging the readings of fast response thermocouples placed at six locations $0.61 \mathrm{~m}$ below the ceiling. As shown in the table, the peak room gas temperature varied from approximately $770^{\circ} \mathrm{C}$ to $1020^{\circ} \mathrm{C}$. Lower temperatures are listed for the first four tests involving unprotective floor assemblies since the tests had to be terminated before the fire was fully developed. 
The total rates of heat released within the fire room were computed from the oxygen used using the procedure similar to that in earlier work [2]. Based on the data for oxygen concentration, gas velocity, and temperature measurements of the outflowing combustion products in the doorway and in the smoke stack, the calculated results for the individual room fires during their fully developed period are summarized in table 6 . In test 7 , there appeared to be some difficulties with the gas sampling system for the doorway oxygen and carbon monoxide concentrations, which caused the former to be high and the latter to be low throughout the test. As shown in the table, the maximum heat release rate was found to range from approximately 3000 to $4100 \mathrm{~kW}$ with an average of $3710 \mathrm{~kW}$ based on the data derived from the doorway measurements, and 5400 to $8500 \mathrm{~kW}$ with a mean value of $7480 \mathrm{~kW}$ from the stack measured data. The higher values at the stack in comparison with those at the doorway were attributed to the additional large quantities of heat evolved from the burning of the excess pyrolysates with the entrained air underneath the exhaust hood outside of the fire room.

The peak level of experimentally determined flow rates of air inflow induced by room fires through the doorway opening varied widely from approximately 0.6 to $0.8 \mathrm{~kg} / \mathrm{s}$ (average $0.69 \mathrm{~kg} / \mathrm{s}$ ) and exhausting gas outflow ranged from 1.6 to $1.8 \mathrm{~kg} / \mathrm{s}$ (average $1.67 \mathrm{~kg} / \mathrm{s}$ ), respectively. The lowest height of the neutral plane in the doorway was found to be relatively constant with an average value of $0.67 \mathrm{~m}$ above the floor level or approximately one-third of the doorway height. The maximum values of static pressures measured at the south wall $0.1 \mathrm{~m}$ below the ceiling ranged from about 13 to $15 \mathrm{~Pa}$ for all test fires.

Measured results of the rate of heat transferred to the selected locations in the room walls and the floor and in front of the doorway outside of the room are summarized in table 7. The average of the highest readings of two heat flux gauges situated in the west and south plywood walls at a distance of $0.61 \mathrm{~m}$ beneath the ceiling is also listed in the table. As shown, the peak level of total flux acting at the walls varied from approximately 100 to $180 \mathrm{~kW} / \mathrm{m}^{2}$ with a mean of $150 \mathrm{~kW} / \mathrm{m}^{2}$ for wood-frame floor assemblies and ranged from 110 to $160 \mathrm{~kW} / \mathrm{m}^{2}$ with an average of $130 \mathrm{~kW} / \mathrm{m}^{2}$ for steel framed floors. The higher wall surface fluxes with wood framings were probably due to thermal emission from the thicker flames at the ceiling in addition to convective and radiant heating from the upper walls and hot gas layer. Also, illustrated in the table, the maximum heat flux incident at the center of the floor was found to vary from about 125 to $160 \mathrm{~kW} / \mathrm{m}^{2}$ with the average value of $140 \mathrm{~kW} / \mathrm{m}^{2}$. The peak rates of heat transferred to a point outside the room and spaced $3.05 \mathrm{~m}$ from the doorway opening from the emerging flames and the room fire were of the order of $40 \mathrm{~kW} / \mathrm{m}^{2}$. 
The peak levels of the optical density of the smoke, the $\mathrm{CO}$ and $\mathrm{CO}_{2}$ gas concentrations, and the lowest oxygen content in the effluent gas measured separately at the doorway and at the smoke stack are shown in table 8 . The maximum concentrations of smoke and toxic combustion products leaving through the doorway opening for all the tests were found to have average values of $3.9 \mathrm{OD} / \mathrm{m}$ for smoke particulates, 10 percent for $\mathrm{CO}$ and 18 percent for $\mathrm{CO}_{2}$ gas. The lower level of $\mathrm{CO}$ observed at the smoke stack than at the doorway was due primarily to further combustion with oxygen and dilution by entrained air before it reached the stack sampling probe.

\subsection{Performance of Test Assemblies}

$\underline{\text { Assembly } 1}$

Flame penetration which occurred near the joint between two sheets of plywood subfloor in the southwest corner, located above the right arm of the sofa, was observed at $10 \mathrm{~min}: 17 \mathrm{sec}$. There was a load failure with the falling of steel blocks onto the floor, resulting from structural collapse of the centrally located wood joist, at $10 \mathrm{~min}: 43 \mathrm{sec}$. The average surface temperature of the carpet finished flooring increased rapidly to $206^{\circ} \mathrm{C}$ at $11 \mathrm{~min}: 7 \mathrm{sec}$ and the individual temperature readings at 2 locations exceeded $240^{\circ} \mathrm{C}$ at $10 \mathrm{~min}: 59 \mathrm{sec}$.

Assembly 2

Failure of the assembly took place at $3 \mathrm{~min}: 47$ sec by the passage of flames through to the unexposed surface near the center of the assembly. The deflection of the test floor measured at the center point showed a rapid increase after $3 \mathrm{~min}: 31 \mathrm{sec}$ and the central joist collapsed at the same time as flame-through. The temperature rise on the unexposed surface in the vicinity of burn-through area reached $163^{\circ} \mathrm{C}$ at $3 \mathrm{~min}: 41 \mathrm{sec}$.

\section{$\underline{\text { Assembly } 3}$}

Flame penetration near the west quarter point along the center joist and the west side of the tongue and groove joint between two sheets of plywood underlayment located above the right seat cushion of the sofa was noticed at $3 \mathrm{~min}: 58 \mathrm{sec}$. Structural collapse of the center joist based on the results of deflection measurements occurred at $3 \mathrm{~min}: 59 \mathrm{sec}$. One thermocouple positioned on the carpet in the neighborhood of the flame-through region indicated a steep temperature rise to $239^{\circ} \mathrm{C}$ at $4 \mathrm{~min}: 7 \mathrm{sec}$. The average temperature rise of the surface thermocouples was less than $45^{\circ} \mathrm{C}$ at the end of the test. 
Deflection measurements at the center of the assembly showed a rapid increase at $11 \mathrm{~min}: 52 \mathrm{sec}$ and the centrally located joist fractured with the falling of steel blocks into the fire room at $12 \mathrm{~min}$. Passage of flames and hot gases through the assembly to the unexposed surface occurred at 12 min:2 sec in an area near the center of the assembly on the southeast side and somewhat away from the thermocouple locations. The average surface temperature on the carpet flooring increased rapidly to $462^{\circ} \mathrm{C}$ at $12 \mathrm{~min}: 8 \mathrm{sec}$, and the individual temperature rise of greater than $163^{\circ} \mathrm{C}$ occurred almost at the same instance of flame penetration.

\section{$\underline{\text { As sembly } 5}$}

Failure of the gypsum board ceiling with falling of small fragments of ceiling materials to the floor was observed at $13 \mathrm{~min}: 9 \mathrm{sec}$. Penetration of flames through the test assembly to the unexposed surface occurred at $15 \mathrm{~min}: 58 \mathrm{sec}$. The flame-through region was located near the west quarter point of the floor joist situated south of the center joist, and at the juncture of the three sheets of plywood in the southwest direction from the center of the assembly. The floor sagged more rapidly with a maximum deflection rate of $6.0 \mathrm{~mm} / \mathrm{s}$ at the time of flame-through, but its joists did not collapse entirely into the test room due to the support from the horizontal steel strap along the longitudinal centerline. However, this deflection rate of the center steel joist exceeded the specific deflection rate of $0.11 \mathrm{~mm} / \mathrm{s}$ calculated based on a criterion of structural failure proposed by Ryan and Robertson [4]. The average temperature rise of the unexposed surface and the individual temperature measured in the vicinity of the flame-through region showed a rapid increase up to 163 and $236^{\circ} \mathrm{C}$, respectively, at time of flame passage.

\section{$\underline{\text { Assembly } 6}$}

The protective layer of gypsum board utilized as the ceiling finish for the assembly failed at $11 \mathrm{~min}: 51 \mathrm{sec}$. During construction of the test assembly, small wood strips 13 x $38 \mathrm{~mm}$ in cross section, were nailed to nominal 51 x $305 \mathrm{~mm}$ wood rim joists to accommodate $305 \mathrm{~mm}$ deep wood trusses. The joints between these two wood pieces were covered with duct tape on the unexposed side of the test room. The flame penetration at one taped joint located above the middle of the west block wall occurred at 17 min:46 sec, which was $7 \mathrm{sec}$ earlier than the passage of flames through the assembly near the center. The temperature rise of one surface thermocouple positioned on the carpet 
exceeded $163^{\circ} \mathrm{C}$ at nearly the same time as the flames passed around the rim joist. The centrally located joist did not fail until $18 \mathrm{~min}: 34$ sec, due primarily to the support of the nominal 51 x $152 \mathrm{~mm}$ wood bridging fastened at mid-span, with common nails.

\section{Assembly 7}

The gypsum board ceiling began to disintegrate and fell away in random fragments onto the floor at $23 \mathrm{~min}: 6 \mathrm{sec}$. Passage of flames through the assembly to the unexposed surface was recorded at $35 \mathrm{~min}: 8 \mathrm{sec}$. An approximately 0.3-m square opening burned away by the fire was situated between the center joist and its adjacent joist to north, and at $0.76 \mathrm{~m}$ from the front wall containing the doorway opening. The records of floor deflection measured at the center of the assembly indicated a significant deflection at 35 min:2 sec, and the maximum downward movement at a rate of $8.4 \mathrm{~mm} / \mathrm{s}$ occurred at $35 \mathrm{~min}: 18 \mathrm{sec}$. The maximum values of the average and the individual temperature rises on the unexposed carpet surface at time of test termination were 69 and $108^{\circ} \mathrm{C}$, respectively, since thermocouple locations were away from the burn-through region.

\section{DISCUSSION}

There are many sources influencing the results of test measurements, such as the variations of test materials and assemblies, environmental conditions, instruments, and calibration techniques. It is not feasible to eliminate these variations completely, particularly the non-uniformity of building materials normally encountered. In order to estimate these uncertainties, a statistical analysis was performed on the experimental data during the period prior to failure of the assembly for the three fire tests from the current floor assembly test series which had gypsum board ceilings and one similar test from the earlier series [2]. The repeatability of large-scale room fire test used for evaluating the fire performance of these selected, load-bearing, floor-ceiling assemblies is discussed elsewhere [5].

Time variations of the average gas temperature in the upper part of the fire room for all the tests conducted are shown in figures 17 and 18 along with the newly developed fire exposure curve. The derived fire exposure curve was obtained by approximating the experimental temperature versus time curve obtained in test 9 from a series of basement room fire tests [2] with a smooth curve. In this particular test, the $3.2 \times 3.2 \mathrm{~m}$ burn room was finished with plywood paneling walls and gypsum board ceiling, and furnished with a typical loading of $23 \mathrm{~kg} / \mathrm{m}^{2}$ of domestic furniture. The newly developed 
temperature-time curve, which corresponded to an approximate average over the range of test conditions examined in the test series, was considered to be more realistic representation of room fires in residential occupancies. The gas temperatures plotted in the figures were the spatial average value at various times of gas temperatures measured with 6 fast response thermocouples located $0.61 \mathrm{~m}$ below the underside of test assembly. As shown in the figures, the temperature levels of the room gases were nearly the same during the fire growth period, significantly varied after room flashover, and then slightly scattered. The gas temperatures attained in the fire room with the exposed wood joist/plywood subfloor as ceiling materials (tests 1 and 4) were considerably lower than those in the rooms lined with gypsum board ceilings (tests 5 to 7) during the fully developed stage. This was due to increased rates of heat absorbed in maintaining the supply of volatile products from the pyrolyzing cellulosic materials and to the dilution of the heated air by the gaseous pyrolysis products which remained unburned in the oxygen-starved atmosphere. It can be noted that the temperature level of room gases in test $7 \mathrm{climbed}$ once again toward the end of the test period due to the gradual and then rapid involvement of the wood joists and plywood subfloor after the disintegration of the protective gypsum board ceiling. The pyrolysis of the plywood had a positive effect on the temperature in the room during this time period because the fire was no longer ventilation-limited and the pyrolysis products were able to burn in the room.

The performance of the various floor-ceiling assemblies in terms of fire resistance periods in the room burnout tests are summarized in table 9 . The fire resistance of the test structures is expressed as the time taken from appearance of sustained flaming of the newspaper on the sofa to (1) passage of flames through openings or cracks developed in the assembly, (2) structural collapse, or (3) the attainment of either an average or a maximum individual temperature on the unexposed surface of 139 or $181^{\circ} \mathrm{C}$, respectively, above its initial temperature, whichever occurs earlier. Also, in the table are the maximum deflections measured at the center of the individual floor constructions. Structural failure of the floors was recorded when the flocr support joists collapsed or when the maximum rate of floor deflection exceeded a specific deflection rate of $0.11 \mathrm{~mm} / \mathrm{s}$ based on load failure criteria [4]. The times taken to collapse of the floor joists determined on the basis of visual observations and video tape records were generally in good agreement with the recorded deflection data.

As illustrated in table 9, failure attributed to penetration of flames through the test structure or collapse of floor joists varied from approximately 4 min for an unprotected steel joisted floor to 35 min for a floor 
with a type $x$ gypsum board protective ceiling. In general, the passage of flames through the assembly usually occurred slightly before structural failure because the deflection of floor joists with increased temperature levels developed openings at the plywood floor joints for flames to pass through. The unprotected floor assemblies consisting mainly of a plywood subfloor supported by steel joists generally failed within 4 min compared to 10 to 12 min for those with wood framing. This was due to small thickness and high thermal conductivity of steel members and the rapid reduction in modulus of. elasticity and yield strength of these structural elements at elevated temperatures, which caused the larger deflections of the floor joists and provided increased joint separation and wider gaps for flame-through. For the fire protective assemblies, the gypsum board ceiling provided a thermal barrier for retarding the heat transmission to the plywood subfloor and the floor joists. The addition of a protective layer of gypsum board on the ceiling increased the fire resistance period approximately 12 min for $13 \mathrm{~mm}$ thick regular board and $23 \mathrm{~min}$ for 16-mm, type $\mathrm{x}$ gypsum board.

It can be noted that the static loads applied to assemblies 2 and 3 were 100 and 74 percent of the respective maximum permissible design loads as given in table 3. As shown in table 9, the collapse times for these two steel frame floors under different applied load conditions did not vary greatly and the difference in time was within 5 percent. While it may be anticipated that the collapse time will be greater for a floor-ceiling assembly with lower loads than those with higher loads, this could not be verified from these limited tests. The floor system used in test 1 involving wood joists stressed to 69 percent of the maximum allowable value and placed $0.41 \mathrm{~m}$ apart had a shorter time to collapse structurally than those employed in test 4 where the load applied to the assembly developed the full design stress in the joists spaced at $0.61 \mathrm{~m}$ on center. This smaller failure time might have resulted from a greater reduction in cross-sectional area due to wood charring as the floor joists were installed parallel to the wall with the doorway opening and probably received a higher heat flux at the exposed surfaces. Also shown in the table, the maximum deflection of the floor assembly for individual tests ranged from approximately 150 to $360 \mathrm{~mm}$. The small deflections for the assemblies used in tests 4 and 7 were probably due to the support of a solid wood bridging installed along the longitudinal centerline.

The time variations of the floor deflections measured at the center of the test assembly for individual tests are shown in figure 19. As shown, the steel framed floors (tests 2, 3, and 5) had similar deflection curves where the deflection became significant only near the time of structural 
failure of the center joist at which time it rose rapidly. The wood floors (tests 1, 4, and 7) were slower to deflect than the steel floors and experienced a period of slowly increasing deflection due to gradual loss of the tensile strength of wood structural elements. The characteristics of the deflection for the assembly framed with wood trusses with steel fasteners (test 6) were intermediate to those of the floors supported by steel and wood joists.

Figure 20 illustrates the floor deflections at the center and the quarter points along the centrally located joist at various times for test 2 . It can be seen from the figure that the rates of deflections at the center and the west quarter point increased more rapidly than that at the east quarter point, although the temperature differences in the room at these locations were less than $60^{\circ} \mathrm{C}$. The temperatures developed in the steel joist at the sections of both quarter points were found to be approximately the same, but the deflection was substantially different, especially at times of imminent collapse of the joist. The reason for this wide variation in deflection during the course of the fire is not known. (Note that the west quarter point was over the sofa where the exposure might be greater for the first 4 minutes.)

The average surface temperatures on the unexposed side of the floorceiling assembly as a function of time for all the tests performed are shown in figure 21. These average temperatures were derived from averaging the readings of 10 thermocouples attached on the carpet surface, including 9 equally spaced thermocouples and one located $1.52 \mathrm{~m}$ from the south edge and $0.76 \mathrm{~m}$ from the west end of the assembly. As would be expected, the unprotected assemblies (tests 1 to 4) had a faster rise in surface temperature than the floor systems with a fire protective ceiling (tests 5 to 7 ). In the tests conducted, the average temperature increases of greater than $139^{\circ} \mathrm{C}$ above the initial temperature on the unexposed surface were not observed before failure by passage of flames through the assembly. As shown, the protective ceiling delayed the time of temperature failure by approximately 12 minutes for $13 \mathrm{~mm}$ gypsum board and more than 23 minutes for $16 \mathrm{mu}$ type $x$ gypsum wallboard.

A comparison of the surface temperatures attained at the top and bottom of the steel joist and that at the top of the plywood subfloor located above the center of the room for the tests with and without a protective ceiling (tests 5 and 3 ) is shown in figure 22. As shown, the temperature in the top flange of the floor joist was consistently lower than that in its bottom surface. This was due to the fact that there was continuous conduction of heat away from the top surface to the cooler plywood subfloor, and for the 
unprotected assembly, the bottom flange received directly more radiant energy than the top one. As would be expected, the surface temperatures of the subfloor increased at a slower rate because of lower thermal conductivity of plywood compared to structural steel.

Figure 23 shows a plot illustrating the relationship between the measured floor deflection at the center of the test assembly and the corresponding average temperature of the centrally located steel joist at the same instance for tests. 2, 3, and 5. The steel temperature was obtained by averaging the readings of the two thermocouples attached to the top and bottom of one cross section along the longitudinal centerline of the test assembly. As shown in the figure, the deformation of the steel joist became greater as the average temperature of the structural element increașed with fire development. Rapid deflection of the assembly occurred and the floor joist failed to support the applied load when the joist reached a temperature level of approximately $650^{\circ} \mathrm{C}$ for the unprotected floor assembly and $820^{\circ} \mathrm{C}$ for the floor with a fire protective ceiling. These steel temperatures were higher than the permissible temperature of $593^{\circ} \mathrm{C}$ for steel structural elements [1]. There was a considerable fall in the steel temperature when the floor deflection was approximately $80 \mathrm{~mm}$ in test 5. This was probably due to the decrease in local air temperatures resulting from the dilution of the heated air surrounding the joist by the gaseous pyrolysis products from the decomposing plywood subfloor. A similar plot of floor deflection versus the average of the surface temperatures measured at the top and bottom of the cross-section located at the middle of the center joist involving wood framed floors for tests 1,4, and 7 is given in figure 24. As shown, significant deflection was not perceived until the average exterior temperatures of wood joists attained a temperature level ranging between 650 and $750^{\circ} \mathrm{C}$. The failure of wooden structural elements was as a result of the reduction in cross sectional area due to charring and burning during the fires. The charred and burned areas were estimated to vary from approximately 53 to 75 percent original cross sectional area for these tests. With the decrease in cross sectional area, the shear and bending stresses increased and the joist failed when these stresses exceeded its yield point.

The time variations of the steel temperatures derived from averaging the values of surface temperatures measured at the top and bottom of the cross sections situated at various locations are shown in figure 25 . It can be noted that the temperatures developed at two locations in the center joist increased more rapidly prior to room flashover than those in the other two neighboring joists due to earlier and direct exposure to the developing fire. However, this temperature difference attributed to relative locations of floor joists involved with the fire reduced with time after flashover. 
The variations in time of the central deflection of the test assembly and the temperatures of the steel joist and room gas located along the vertical centerline of the test room for test 3 are shown in figure 26 . As shown, the temperatures attained in steel member closely followed the temperature levels of surrounding gas, which depended upon the fire process. This was attributed to small thermal inertia because of the relatively high thermal conductivity and small thickness of steel joists used in the assembly. Also shown in the figure, the floor deflection increased with an increase in the joist temperatures.

\section{SUMMARY}

Based on the experimental results of 7 room burnout tests to evaluate the performance of protected and unprotected, load-bearing, wood and steel framed residential floors subjected to a newly developed fire exposure condition, the following observations were made:

(1) The unprotected light gauge steel-framed assemblies allowed the passage of flames and suffered structural collapse in 4 minutes compared to approximately 10 minutes for the exposed wood frame floors.

(2) The use of a $13 \mathrm{~mm}$ thick regular or a $16 \mathrm{~mm}$ thick type $x$ gypsum board ceiling increased the endurance time by about $12 \mathrm{~min}$ and $23 \mathrm{~min}$, respectively.

(3) Under fire exposure, wood framed floors deflected at a slower rate compared to steel-framed floors; their ultimate collapse is ascribed to gradual reduction in the cross sectional area of floor joists caused by the charring and burning of wood.

(4) Failure due to passage of flames to the unexposed surface of the floor structure resulted from the increased deflection of floor joists with elevated temperatures, which promoted joint separation al.d developed openings in the plywood subfloor.

\section{ACKNOWLEDGEMENTS}

The author would like to express his gratitude to many members of the Fire Performance Evaluation Division for their assistance in this study, especially, Messrs. Thomas Maher and Oscar Owens for constructing the test rooms and floor assemblies, Mr. Newton Breese for reducing and processing the experimental data, and Messrs. Sam Steel, Charles Veirtz, William Bailey, 
Roy Lindauer, Douglas Walton, Billy Lee, and Randy Lawson for assistance in performing the fire tests.

The author wishes to thank Ward Corporation in Rockville, Maryland, for providing the wood trusses used in test 6 .

This project was supported in part by the U.S. Department of Housing and Urban Development, under the program management of Mr. James C. McCollom within the Division of Energy, Building Technology and Standards, office of Policy Development and Research.

\section{REFERENCES}

[1] "Standard Methods of Fire Tests of Building Construction and Materials," ANSI/ASTM El19, 1978 Annual Book of ASTM Standards, Part 18, pp. 763-781, (American Society for Testing and Materials, Philadelphia, Pa., 1978).

[2] Fang, J. B. and Breese, J. N., Fire Development in Residential Basement Rooms, NBSIR (in progress).

[3] Issen, L. A., Single Family Residential Fire and Live Loads Survey, NBSIR (in progress).

[4] Ryan, J. V. and Robertson, A. F., Proposed Criteria for Defining Load Failure of Beams, Floors and Roof Constructions During Fire Tests, J. of Res. NBS, 63C, 121-124 (1959).

[5] Fang, J. B., Repeatability of Large-scale Room Fire Tests, a paper for publication (in progress).

[6] "Design Values for Wood Construction," National Forest Products Association, June 1978 . 


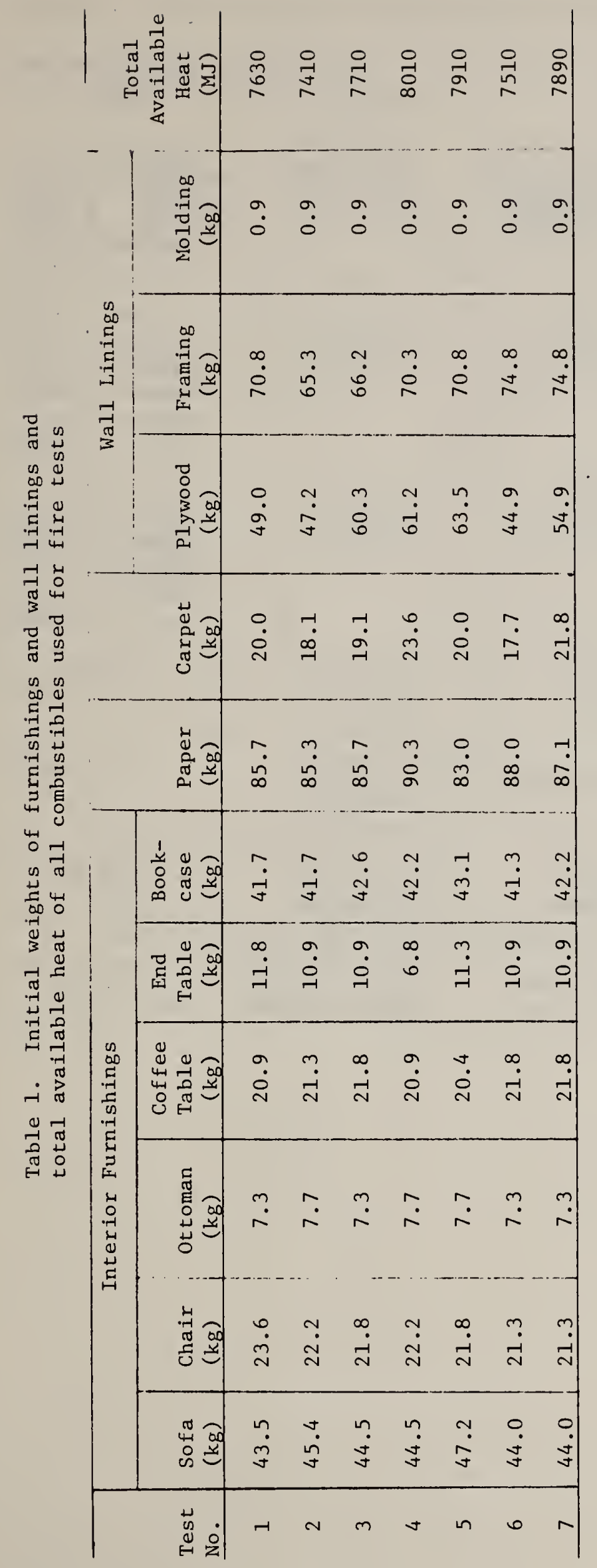


Table 2. Descriptions of combustible contents

\begin{tabular}{|c|c|c|c|}
\hline Item & Material & Size & $\begin{array}{l}\text { Initial Weight } \\
(\mathrm{kg})\end{array}$ \\
\hline Sofa & $\begin{array}{l}\text { Grade } 1,100 \% \text { olefin upholstery } \\
\text { fabric, cotton batting side arms, } \\
\text { foamed polyurethane seat, back } \\
\text { and side cushions, wood frame }\end{array}$ & $\begin{array}{l}2.15 \mathrm{~m} \text { wide } \mathrm{x} \\
0.85 \mathrm{~m} \text { deep } \mathrm{x} \\
0.81 \mathrm{~m} \mathrm{high}\end{array}$ & $\begin{array}{l}47 \\
\text { (frame }-24 \mathrm{~kg} \text {, } \\
\text { foam }-6.8 \mathrm{~kg}, \\
\text { cover }-6.4 \mathrm{~kg} \\
\text { batting, etc. - } \\
\quad 9.8 \mathrm{~kg} \text { ) }\end{array}$ \\
\hline $\begin{array}{l}\text { Upholstered } \\
\text { Chair }\end{array}$ & $\begin{array}{l}\text { Grade } 1,100 \% \text { olefin cover } \\
\text { fabric, urethane foam seat } \\
\text { cushion, cotton batting, wood } \\
\text { frame }\end{array}$ & $\begin{array}{l}0.79 \text { m } W x \\
0.91 \text { m } D x \\
0.93 \text { m } H\end{array}$ & $\begin{array}{l}23 \\
\text { (frame }-11.3 \mathrm{~kg} \\
\text { foam }-2.3 \mathrm{~kg} \\
\text { cover }-1.8 \mathrm{~kg} \\
\text { batting, etc. }- \\
7.6 \mathrm{~kg} \text { ) }\end{array}$ \\
\hline Ottoman & $\begin{array}{l}\text { Grade } 1,100 \% \text { olefin cover } \\
\text { fabric, urethane foam, wood } \\
\text { frame }\end{array}$ & $\begin{array}{l}0.61 \mathrm{~mW} x \\
0.46 \mathrm{mD} x \\
0.43 \mathrm{mH}\end{array}$ & $\begin{array}{c}7.7 \\
\text { (frame }-4.5 \mathrm{~kg} \\
\text { foam }-0.9 \mathrm{~kg} \\
\text { cover }-0.9 \mathrm{~kg} \\
\text { batting, etc. } \\
1.4 \mathrm{~kg} \text { ) }\end{array}$ \\
\hline $\begin{array}{l}\text { Coffee } \\
\text { Table }\end{array}$ & $\begin{array}{l}\text { Laminated veneer top and } \\
\text { sides, finished hardwood }\end{array}$ & $\begin{array}{l}1.52 \mathrm{~mW} x \\
0.51 \mathrm{mD} x \\
0.41 \mathrm{mH}\end{array}$ & $21 \mathrm{~kg}$ \\
\hline $\begin{array}{l}\text { End } \\
\text { Table }\end{array}$ & $\begin{array}{l}\text { Laminated veneer top and sides, } \\
\text { finished hardwood }\end{array}$ & $\begin{array}{l}0.58 \mathrm{~mW} x \\
0.69 \mathrm{mD} x \\
0.51 \mathrm{mH}\end{array}$ & $10.4 \mathrm{~kg}$ \\
\hline Bookcase & $\begin{array}{l}\text { Wood particle board with } \\
\text { melamine finished surface }\end{array}$ & $\begin{array}{l}0.76 \mathrm{~mW} x \\
0.36 \mathrm{mD} x \\
1.83 \mathrm{mH}\end{array}$ & $42 \mathrm{~kg}$ \\
\hline Carpet & $\begin{array}{l}\text { Olefin pile with rubber foam } \\
\text { cushlon backing }\end{array}$ & $\begin{array}{l}3.2 \times 3.2 \mathrm{~m} \\
\times 9.5 \mathrm{~mm} \text { thick }\end{array}$ & $20 \mathrm{~kg}$ \\
\hline
\end{tabular}


Table 3. Descriptions of test assemblies and loading conditions

\begin{tabular}{|c|c|c|c|c|c|c|c|c|c|}
\hline \multirow[b]{2}{*}{$\begin{array}{l}\text { Test } \\
\text { No. }\end{array}$} & \multicolumn{5}{|c|}{ Structural Elements } & \multirow[b]{2}{*}{$\begin{array}{l}\text { Joist } \\
\text { Spacing }\end{array}$} & \multirow[b]{2}{*}{$\begin{array}{l}\text { Applie } \\
\mathrm{kg} / \mathrm{m}^{2}\end{array}$} & \multirow[b]{2}{*}{$\begin{array}{l}\text { Load } \\
\mathrm{lb} / \mathrm{ft}^{2}\end{array}$} & \multirow[b]{2}{*}{$\begin{array}{l}\text { Percent } \\
\quad \text { of } \\
\text { Maximum } \\
\text { Allowable } \\
\text { Stress }\end{array}$} \\
\hline & $\begin{array}{l}\text { Floor } \\
\text { Joists* }\end{array}$ & \multicolumn{2}{|c|}{$\begin{array}{l}\text { Plywood } \\
\text { Subfloor** } \\
\text { Thickness } \\
\mathrm{mm} \text { in }\end{array}$} & \multicolumn{2}{|c|}{$\begin{array}{l}\text { Painted } \\
\text { Gypsum } \\
\text { Board } \\
\text { Ceiling } \\
\text { Thickness }\end{array}$} & & & & \\
\hline 1 & $\begin{array}{l}\text { Wood } \\
\text { Joists }\end{array}$ & 15.9 & $5 / 8$ & none & none & $0.41 \quad 16$ & 195 & 40 & 69 \\
\hline 2 & $\begin{array}{l}\text { Steel } \\
\text { Joists } \\
\end{array}$ & 15.9 & $5 / 8$ & none & none & $0.61 \quad 24$ & 352 & 72 & 100 \\
\hline 3 & $\begin{array}{l}\text { Steel } \\
\text { Joists }\end{array}$ & 19.1 & $3 / 4$ & none & none. & $0.81 \quad 32$ & 195 & 40 & 74 \\
\hline 4 & $\begin{array}{l}\text { Wood } \\
\text { Joists }\end{array}$ & 18.3 & $23 / 32$ & none & none & 0.6124 & 195 & 40 & 100 \\
\hline 5 & $\begin{array}{l}\text { Steel } \\
\text { Joists }\end{array}$ & 18.3 & $23 / 32$ & 12.7 & $1 / 2$ & $0.61 \quad 24$ & 327 & 67 & 100 \\
\hline 6 & $\begin{array}{l}\text { Wood } \\
\text { Trusses }\end{array}$ & 18.3 & $23 / 32$ & 12.7 & $1 / 2$ & 0.6124 & 327 & 67 & 100 \\
\hline 7 & $\begin{array}{l}\text { Wood } \\
\text { Joists }\end{array}$ & 18.3 & $23 / 32$ & $\begin{array}{c}15.9 \\
\text { (Type } \\
\text { X) }\end{array}$ & $\begin{array}{c}5 / 8 \\
\text { (Type } \\
\text { X) }\end{array}$ & $0.61 \quad 24$ & 195 & 40 & 100 \\
\hline
\end{tabular}

*Wood Joists, nominal $51 \times 203 \mathrm{~mm}(2 \times 8$ in)

Steel Joists, $44.5 \mathrm{~mm}$ wide $\times 184.2 \mathrm{~mm}$ deep $\times 1.3 \mathrm{~mm}$ thick $(1-3 / 4 \times 7-1 / 4$ in $\times 18 \mathrm{ga})$, Super - C

Wood Trusses, $88.9 \mathrm{~mm}$ wide $\times 304.8 \mathrm{~mm}$ deep (3-1/2 $\times 12 \mathrm{in})$, prefabricated with nominal $51 \times 102 \mathrm{~mm}$ ( $2 \times 4$ in) wood chords and webs

Span of all joists was $3.25 \mathrm{~m}(10.67 \mathrm{ft})$

**An olefin carpet with foam rubber backing was installed over the plywood subfloor. 
Table 4. Initial weights and potential heat of combustible materials in test assemblies

\begin{tabular}{|c|c|c|c|c|c|c|c|}
\hline \multirow[b]{2}{*}{$\begin{array}{c}\text { Test } \\
\text { Assembly }\end{array}$} & \multicolumn{6}{|c|}{ Initial Weights of the Combustibles $\mathrm{kg}$} & \multirow[b]{2}{*}{$\begin{array}{c}\text { Potential } \\
\text { Heat } \\
\text { MJ }\end{array}$} \\
\hline & $\begin{array}{l}\text { Floor } \\
\text { Joists }\end{array}$ & Bridging & $\begin{array}{l}\text { Plywood } \\
\text { Subf loor }\end{array}$ & $\begin{array}{l}\text { Olefin } \\
\text { Carpet }\end{array}$ & $\begin{array}{c}\text { S111 } \\
\text { Plates }\end{array}$ & $\begin{array}{c}\text { Rim } \\
\text { Jo1sts }\end{array}$ & \\
\hline 1 & 113.9 & 10.9 & 129.7 & 25.4 & 48.7 & 50.8 & 7770 \\
\hline 2 & 0 . & 0. & 120.2 & 24.0 & 41.7 & 42.2 & 4910 \\
\hline 3 & 0. & 0. & 125.2 & 25.4 & 42.6 & 42.6 & 5090 \\
\hline 4 & 98.6 & 9.5 & 126.6 & 23.6 & 56.4 & 56.4 & 7560 \\
\hline 5 & 0. & 0 . & 106.1 & 24.0 & 45.4 & 49.0 & 4850 \\
\hline 6 & 203.2 & 8.2 & 126.6 & 23.1 & 47.2 & 92.5 & 9960 \\
\hline 7 & 95.3 & 9.1 & 114.3 & 29.9 & 54.4 & 54.4 & 7480 \\
\hline
\end{tabular}




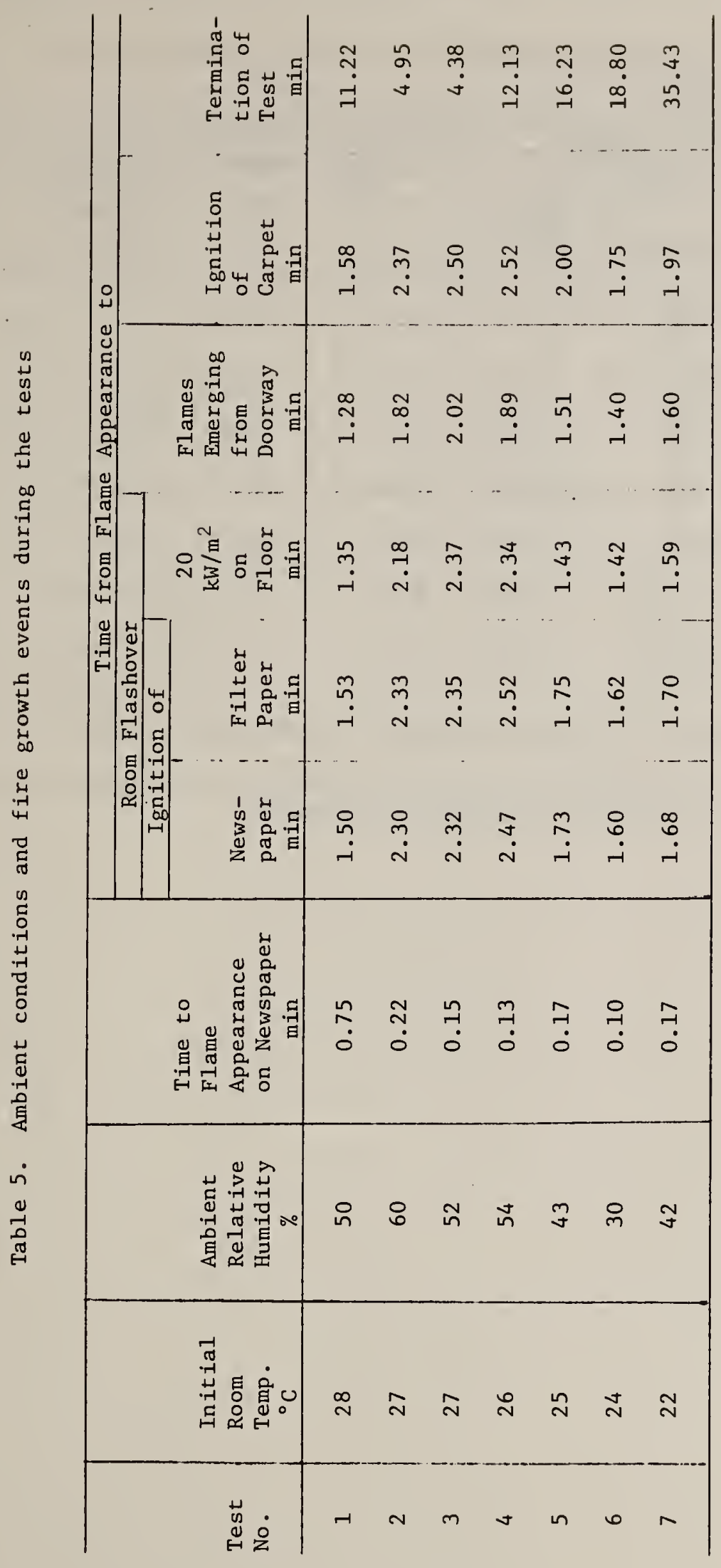


Table h. Summary of various measurements during fully developed stage

\begin{tabular}{|c|c|c|c|c|c|c|c|}
\hline \multirow[b]{2}{*}{$\begin{array}{l}\text { Test } \\
\text { No. }\end{array}$} & \multirow{2}{*}{$\begin{array}{c}\text { Maximum } \\
\text { Average } \\
\text { Upper Room } \\
\text { Gas } \\
\text { Temperature } \\
{ }^{\circ} \mathrm{C} \\
\end{array}$} & \multicolumn{2}{|c|}{$\begin{array}{c}\text { Maximum Heat } \\
\text { Release Rate } \\
\mathrm{kW}\end{array}$} & \multicolumn{2}{|c|}{$\begin{array}{l}\text { Maximum Flow Rate } \\
\text { Through Doorway } \\
\mathrm{kg} / \mathrm{s}\end{array}$} & \multirow{2}{*}{$\begin{array}{l}\text { Minimum } \\
\text { Neutral } \\
\text { Plane } \\
\text { Height } \\
\quad \text { m } \\
\end{array}$} & \multirow{2}{*}{$\begin{array}{l}\text { Maximum } \\
\text { Room } \\
\text { Static } \\
\text { Pressure } \\
\text { Pa }\end{array}$} \\
\hline & & Doorway & $\begin{array}{l}\text { Smoke } \\
\text { Stack }\end{array}$ & In & Out** & & \\
\hline 1 & 923 & 3720 & --- & 0.65 & 1.60 & 0.67 & 13.7 \\
\hline 2 & 779 & 3620 & --- & 0.70 & 1.63 & 0.66 & 14.4 \\
\hline 3 & 773 & 2980 & 8280 & 0.64 & 1.56 & 0.70 & 13.3 \\
\hline 4 & 894 & 3790 & 8460 & 0.63 & 1.67 & 0.64 & 14.2 \\
\hline 5 & 1012 & 4110 & 8470 & 0.73 & 1.76 & 0.68 & 15.2 \\
\hline 6 & 1019 & 4030 & 6860 & 0.80 & 1.73 & 0.66 & 15.4 \\
\hline 7 & 991 & $2950 *$ & 5350 & 0.69 & 1.77 & 0.70 & --- \\
\hline
\end{tabular}

* Low value is questionable due to some difficulties in the oxygen sampling system.

** The density of the combustion products flowing out through the doorway is assumed to be the same as that of dry air in outflow rate calculations. 
Table 7. Incident heat fluxes measured at various locations

\begin{tabular}{|c|c|c|c|c|c|c|c|c|c|}
\hline \multirow{3}{*}{$\begin{array}{l}\text { Test } \\
\text { To. } \\
\text { No. }\end{array}$} & \multicolumn{5}{|c|}{ At Walls } & \multicolumn{2}{|c|}{ At Floor } & \multicolumn{2}{|c|}{$\begin{array}{l}\text { Outside } \\
\text { of Room }\end{array}$} \\
\hline & \multicolumn{3}{|c|}{ Total } & \multicolumn{2}{|c|}{ Radiative } & \multirow[b]{2}{*}{$\begin{array}{l}\text { Time } \\
\text { min. }\end{array}$} & \multirow{2}{*}{$\begin{array}{l}\text { Total } \\
\text { Max. } \\
\mathrm{kW} / \mathrm{m}^{2}\end{array}$} & \multirow[b]{2}{*}{$\begin{array}{l}\text { Time } \\
\text { min. }\end{array}$} & \multirow{2}{*}{$\begin{array}{l}\text { Total } \\
\mathrm{Max} . \\
\mathrm{kW} / \mathrm{m}^{2}\end{array}$} \\
\hline & $\begin{array}{l}\text { Time } \\
\text { min. }\end{array}$ & $\begin{array}{l}\mathrm{Max} \cdot \mathrm{i}^{2} \\
\mathrm{~kW} / \mathrm{m}^{2}\end{array}$ & $\begin{array}{l}\text { Ave. } \\
\mathrm{kW} / \mathrm{m}^{2}\end{array}$ & $\begin{array}{l}\text { Time } \\
\text { min. }\end{array}$ & $\begin{array}{l}\text { Max. } \\
\mathrm{kW} / \mathrm{m}^{2}\end{array}$ & & & & \\
\hline 1 & 11.12 & 104 & 98 & --- & --- & 2.45 & 164 & 2.85 & 44 \\
\hline 2 & 3.78 & 113 & 113 & --- & --- & 2.85 & 163 & 3.48 & 38 \\
\hline 3 & 2.05 & 109 & 93 & --- & --- & 3.05 & 159 & 3.72 & 39 \\
\hline 4 & 12.17 & 130 & 118 & --- & --- & 3.17 & 139 & 4.37 & 42 \\
\hline 5 & 12.50 & 158 & 122 & --- & --- & 2.36 & 128 & 3.13 & 39 \\
\hline 6 & 10.17 & 181 & 156 & 11.10 & 175 & 2.43 & 125 & 2.30 & 35 \\
\hline 7 & 9.16 & 179 & 160 & 4.10 & 167 & 2.63 & 133 & 3.16 & 38 \\
\hline
\end{tabular}


Table 8. Optical density of smoke and gas concentration of outflowing gases

\begin{tabular}{|c|c|c|c|c|c|c|c|c|}
\hline \multirow[b]{3}{*}{$\begin{array}{l}\text { Test } \\
\text { No. }\end{array}$} & \multirow{2}{*}{\multicolumn{2}{|c|}{$\begin{array}{c}\text { Maximum Optical } \\
\text { Density of Smoke, } \\
\text { OD } / \mathrm{m}\end{array}$}} & \multirow{2}{*}{\multicolumn{2}{|c|}{$\begin{array}{l}\text { Minimum } 0_{2} \\
\text { Concentration, } \\
\text { Vol. } \%\end{array}$}} & \multicolumn{4}{|c|}{ Maximum Concentration, Vol. $\% * *$} \\
\hline & & & & & & & $\mathrm{C}$ & \\
\hline & $\begin{array}{l}\text { Doorway } \\
\text { (Avg.) }\end{array}$ & Hood & $\begin{array}{l}\text { Doorway } \\
\text { (Avg.) }\end{array}$ & Stack & $\begin{array}{l}\text { Doorway } \\
\text { (Avg.) }\end{array}$ & Stack & $\begin{array}{l}\text { Doorway } \\
\text { (Avg.) }\end{array}$ & Stack \\
\hline 1. & 4.08 & 2.50 & 0.36 & 7.71 & 11.1 & -- & 19.4 & 10.5 \\
\hline 2 & 4.62 & 2.79 & 0.69 & 9.56 & 9.83 & --- & 17.2 & 10.9 \\
\hline 3 & 4.34 & 1.68 & 0.86 & 8.90 & 10.2 & 0.54 & 17.1 & 10.8 \\
\hline 4 & 3.87 & 2.60 & 0.0 & 9.10 & 11.8 & 0.66 & 19.7 & 11.2 \\
\hline 5 & 3.00 & 2.89 & 0.22 & 9.66 & 10.7 & --- & --- & 11.5 \\
\hline 6 & 3.60 & 2.28 & 0.24 & 10.5 & 9.6 & 0.51 & -- & 9.75 \\
\hline 7 & 3.94 & 2.62 & 0.73 & 10.7 & $5.91 *$ & 0.28 & -- & 8.05 \\
\hline
\end{tabular}

*Low value was due to problems with gas sampling system.

**The maximum concentrations of $\mathrm{CO}$ and $\mathrm{CO}_{2}$ gases did not occur at the same time. 
Table 9. Summary of the fire resistance period of floor assemblies in room burnout tests

\begin{tabular}{l|c|c|c|c|c|c}
\hline \multirow{2}{*}{$\begin{array}{c}\text { Assembly } \\
\text { No. }\end{array}$} & \multicolumn{2}{|c|}{ Time to } & \multicolumn{2}{c|}{$\begin{array}{c}\text { Time for the Unexposed } \\
\text { Surface to Increase }\end{array}$} & \multicolumn{2}{c}{$\begin{array}{c}\text { Maximum } \\
\text { Deflection }\end{array}$} \\
\cline { 2 - 7 } & $\begin{array}{c}\text { Flame } \\
\text { Through } \\
\text { min:sec }\end{array}$ & $\begin{array}{c}\text { Structural } \\
\text { Failure } \\
\text { min:sec }\end{array}$ & $\begin{array}{c}\text { Avg. Temp. } \\
139 \text { deg C } \\
\text { min:sec }\end{array}$ & $\begin{array}{c}1 \text {-point Temp. } \\
181 \text { deg C } \\
\text { min:sec }\end{array}$ & $\begin{array}{c}\text { Time } \\
\text { min:sec }\end{array}$ & $\begin{array}{c}\text { Center } \\
\text { Point } \\
\text { mm }\end{array}$ \\
\hline 1 & $10: 17$ & $10: 43$ & $11: 02$ & $10: 56$ & $10: 43$ & 364 \\
2 & $3: 47$ & $3: 47$ & $3: 50$ & $3: 41$ & $3: 47$ & 362 \\
3 & $3: 58$ & $3: 59$ & N.R. & $4: 04$ & $4: 07$ & 330 \\
4 & $12: 02$ & $12: 00$ & $12: 08$ & $12: 02$ & $12: 00$ & 176 \\
5 & $15: 58$ & $15: 58 *$ & $15: 57$ & $15: 55$ & $16: 14$ & 328 \\
7 & $17: 53$ & $18: 34$ & N.R. & $17: 43$ & $18: 34$ & 325 \\
\hline
\end{tabular}

* No joist collapse, times refer to excessive deflection rate [4]. N.R. - not reached 


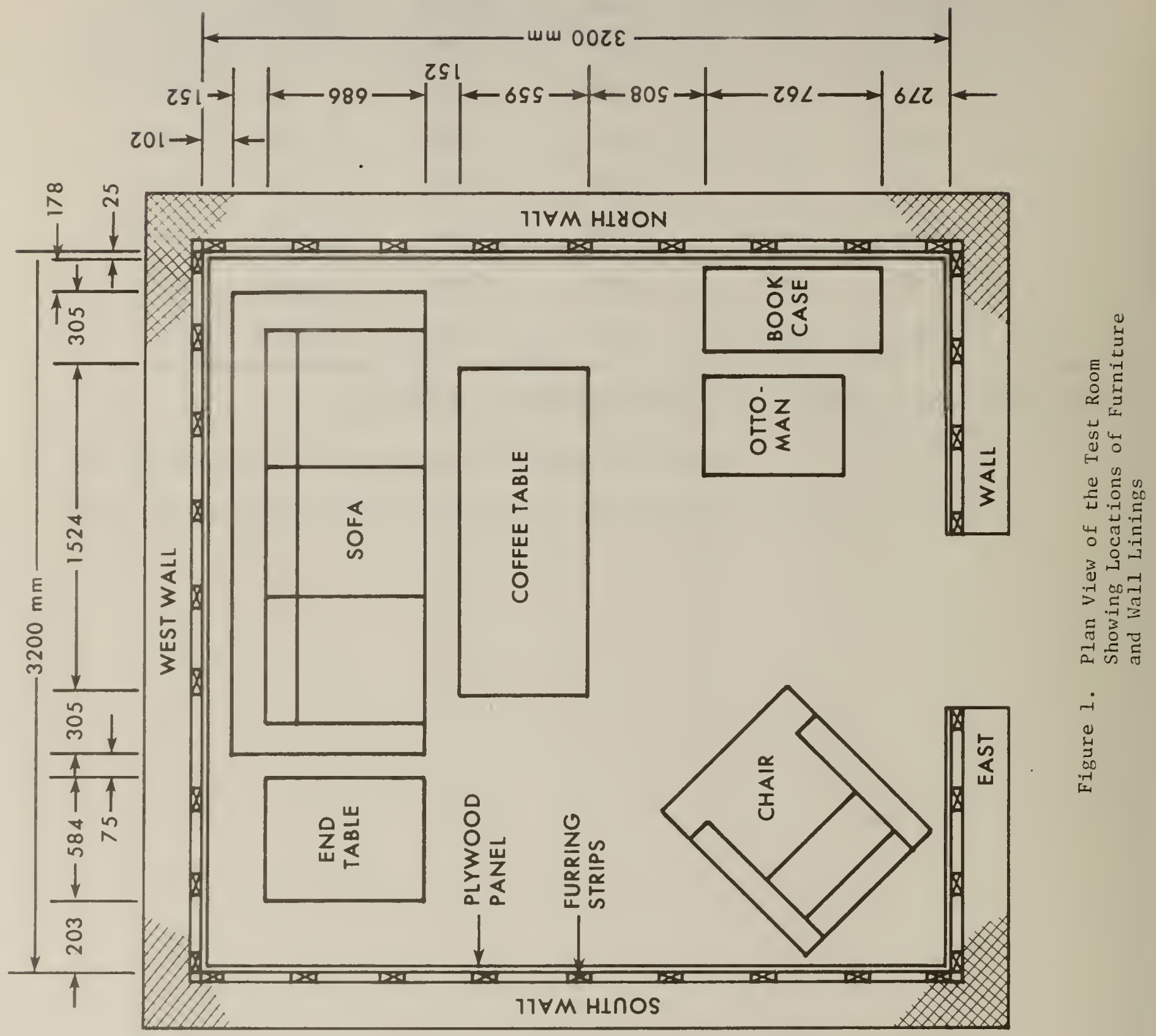


Key to Figures 2 to 6 , and 9 to 10

Symbol

Type of Transducers

Locations

0

Displacement Potentiometer

Center and quarter-points of floor joists

1 Thermocouple

On the top of carpet

0

3 Thermocouples

At the bottom and top of floor joist, and on the unexposed surface of plywood subfloor

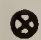

1 Thermocouple

(tests 5 to 7 )

On the exposed surface of gypsum board ceiling. 


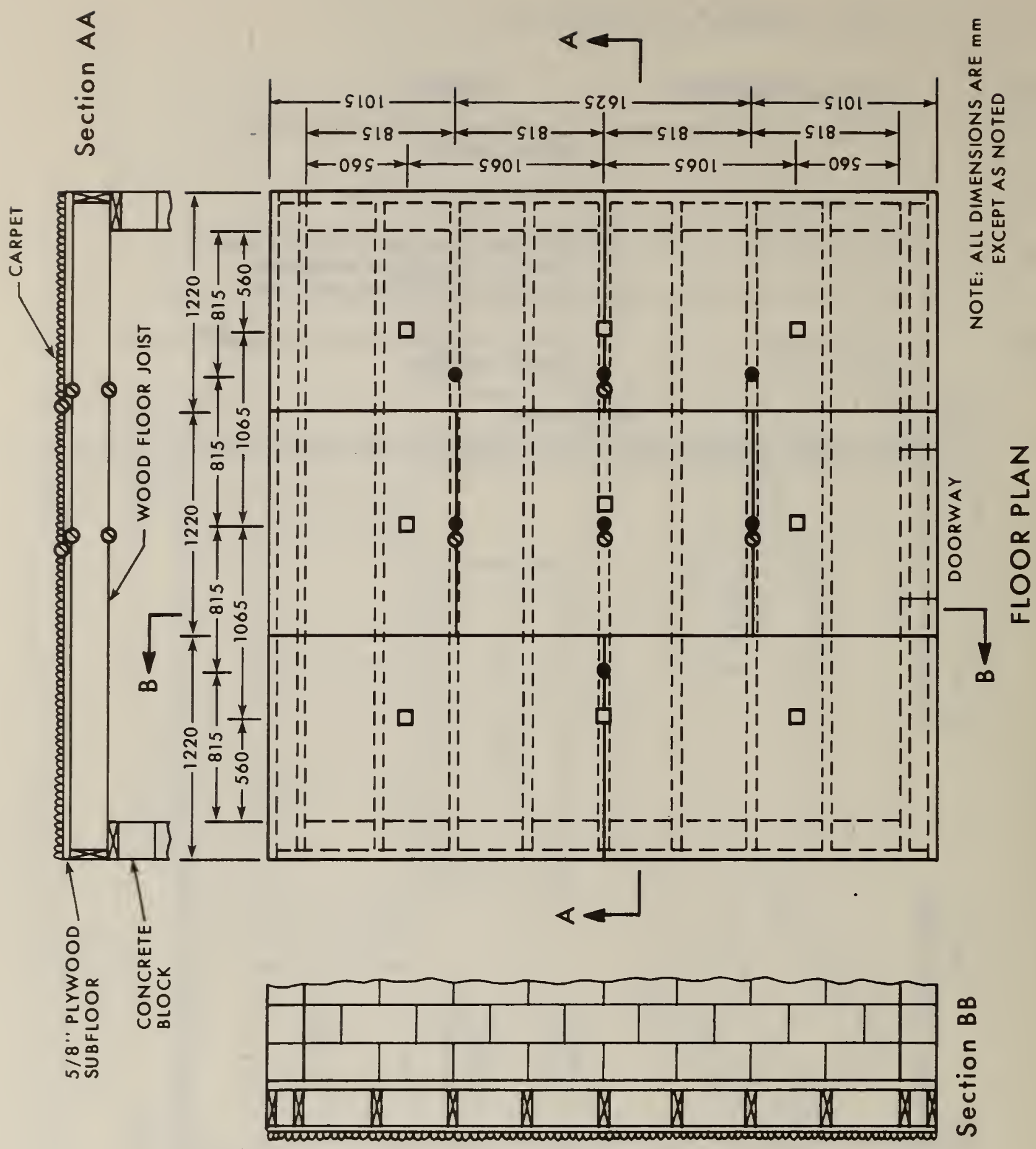



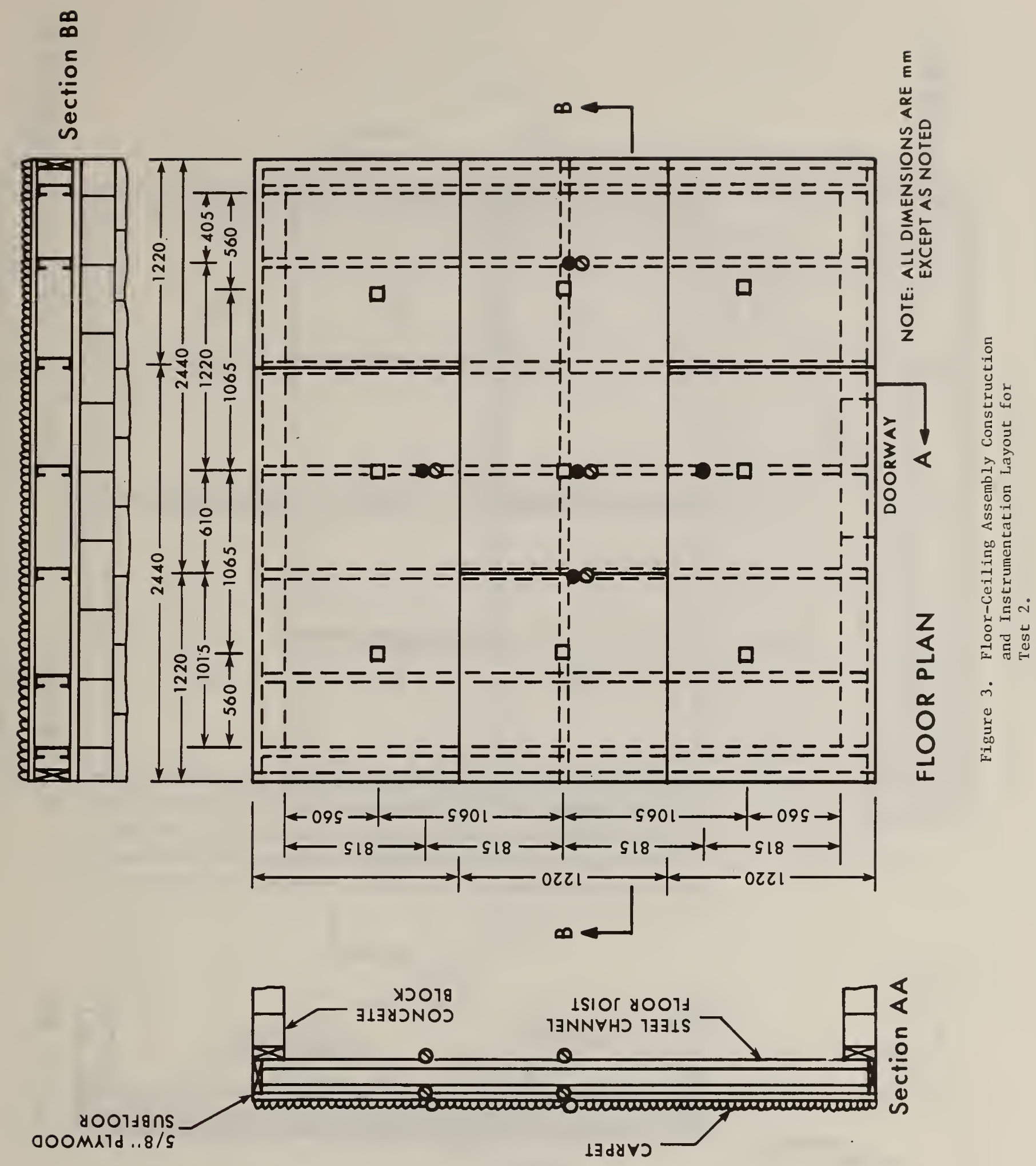

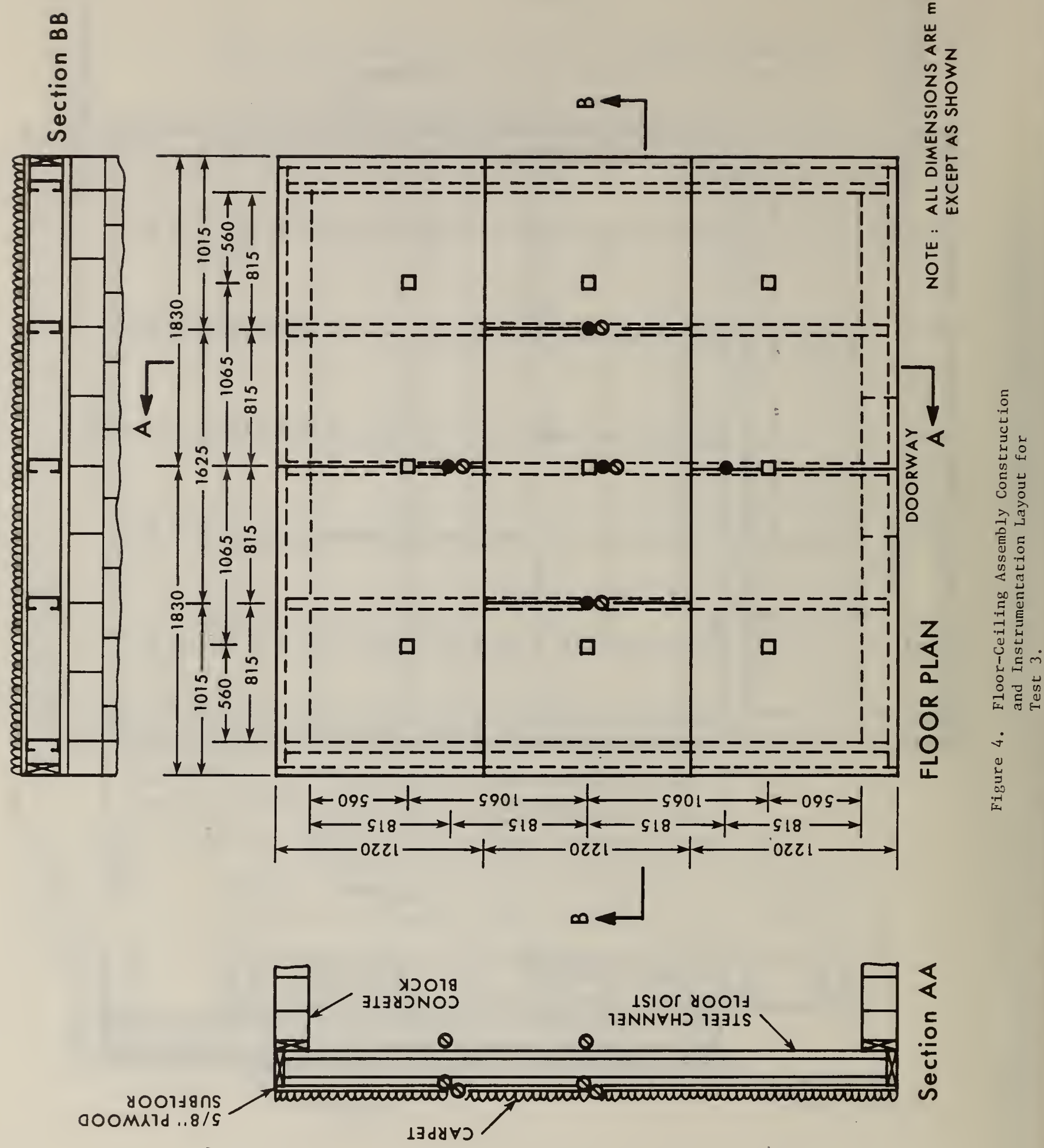


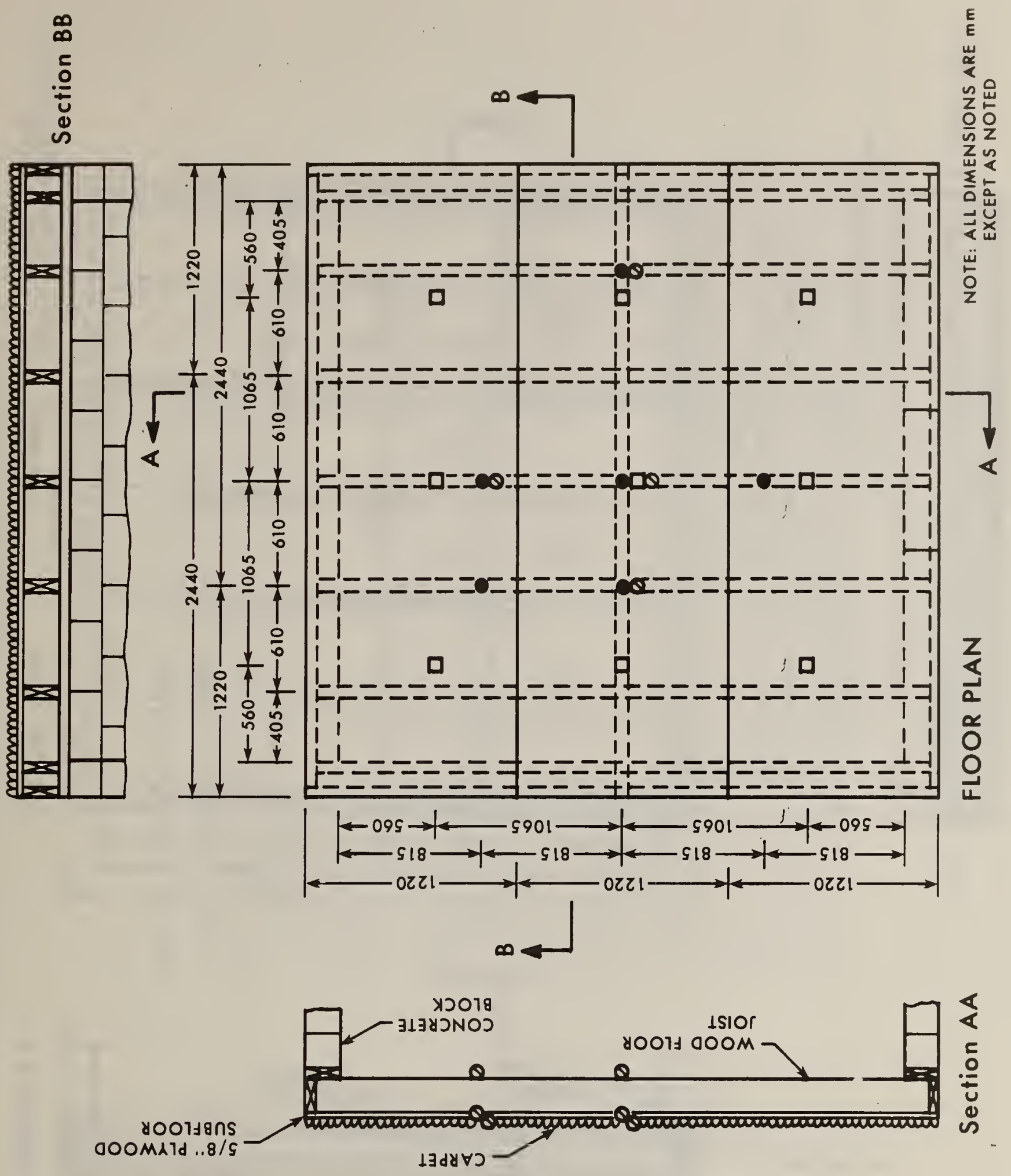




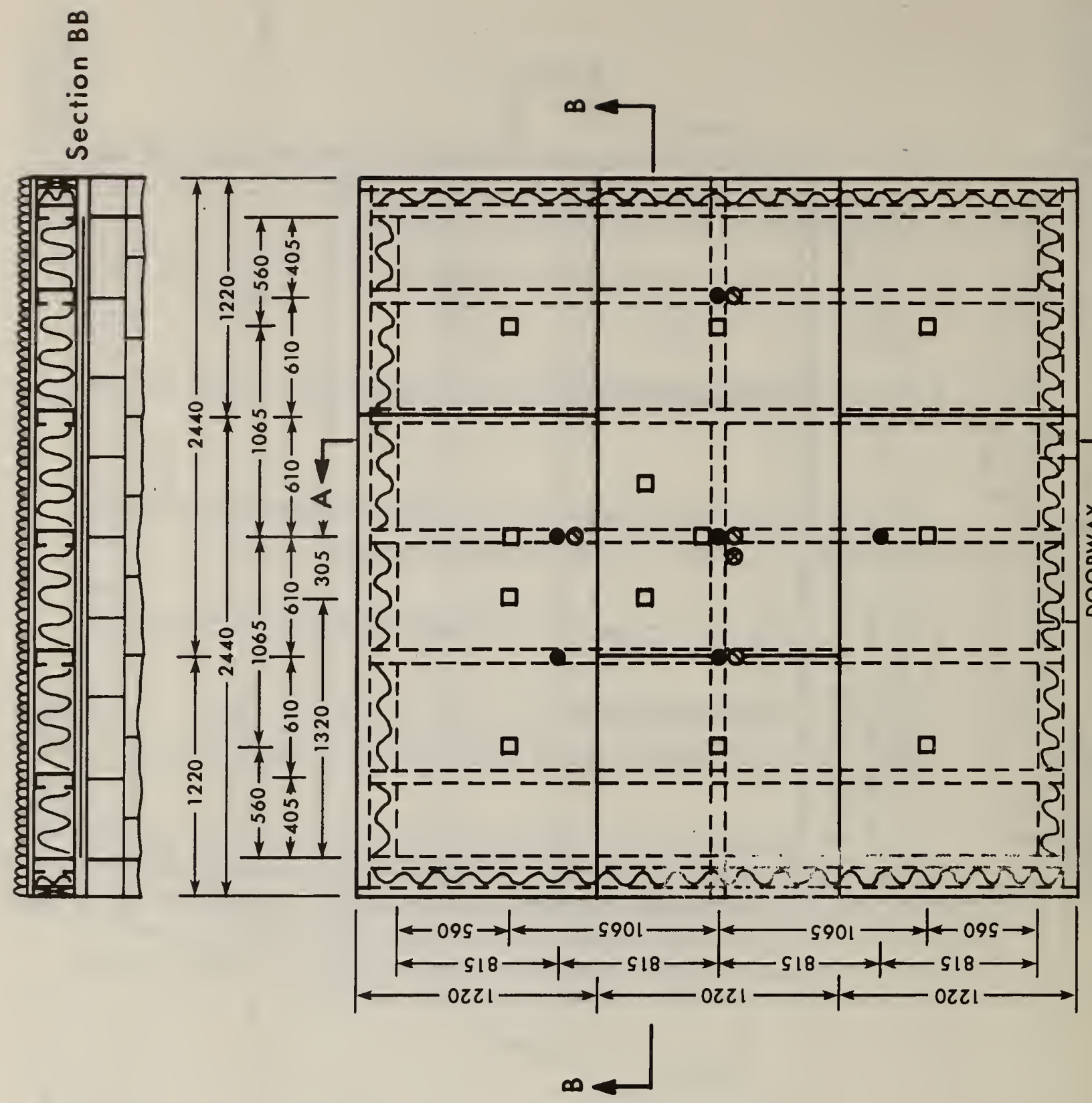

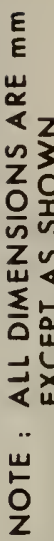

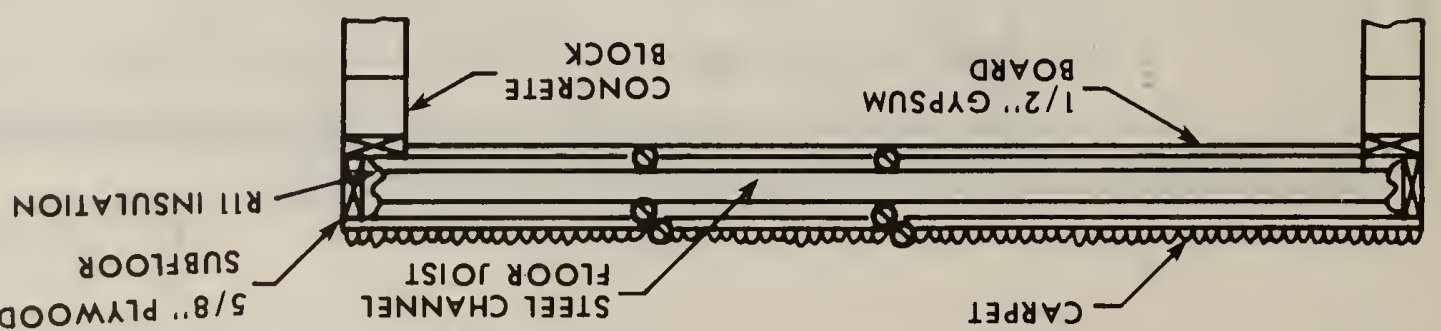

$\frac{5}{4}$
$\frac{5}{0}$
$\vdots$
0
0 


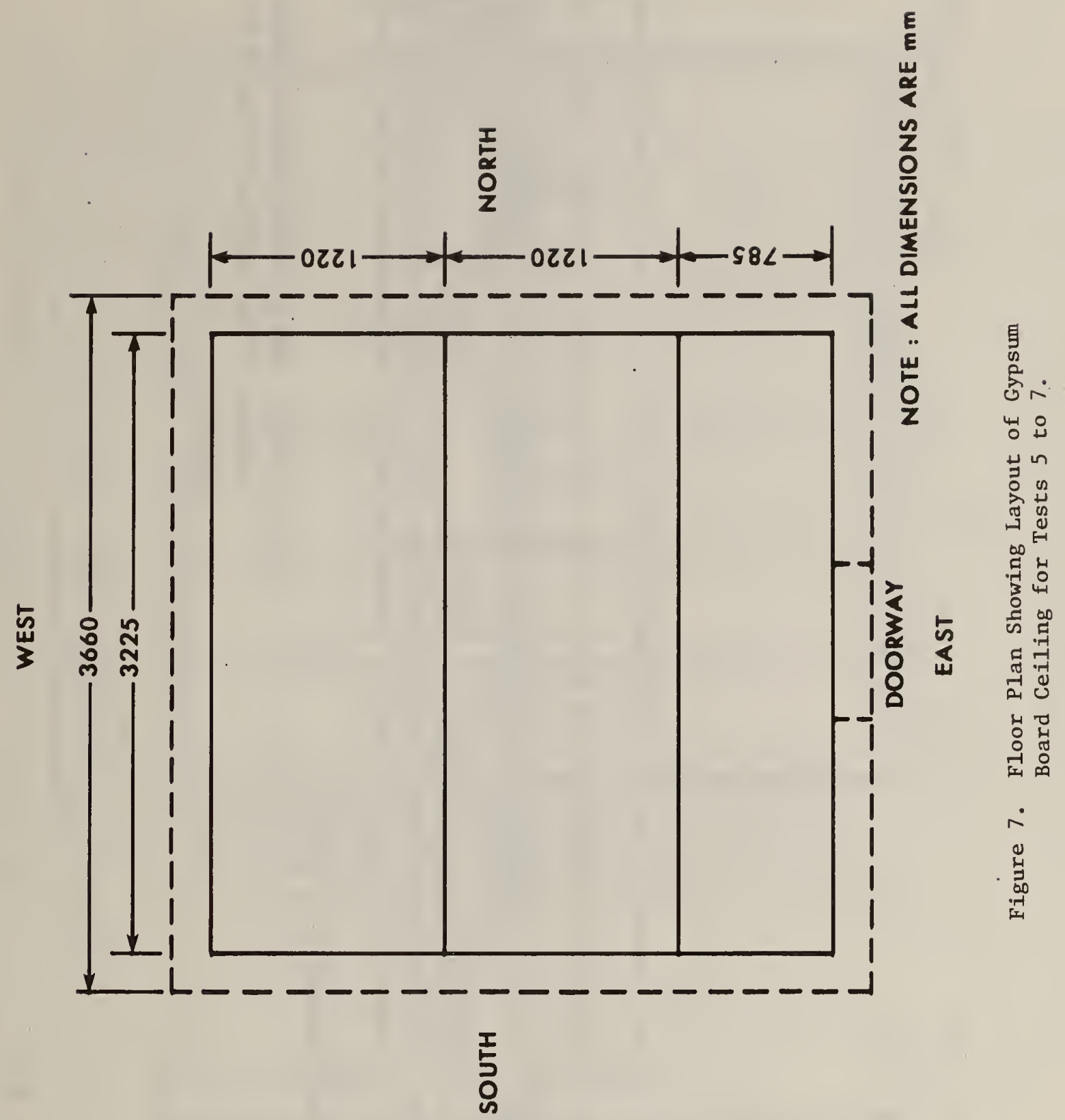




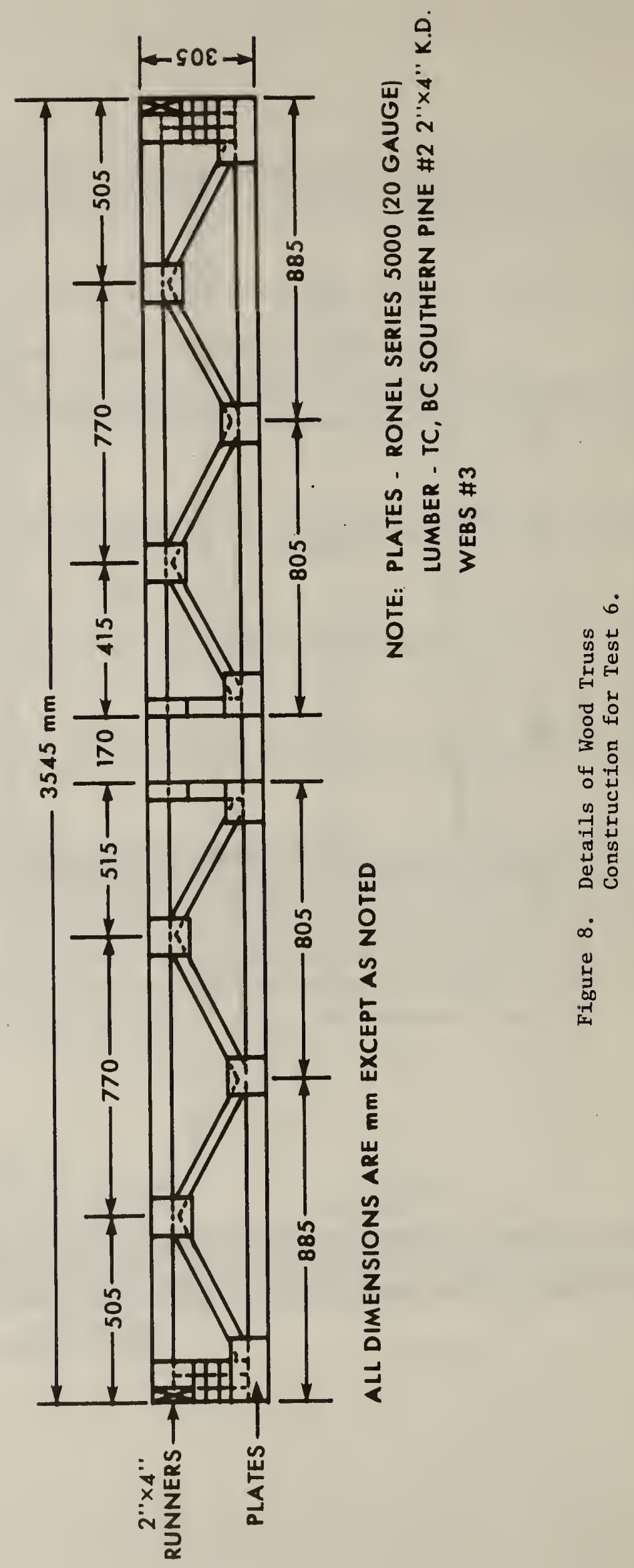



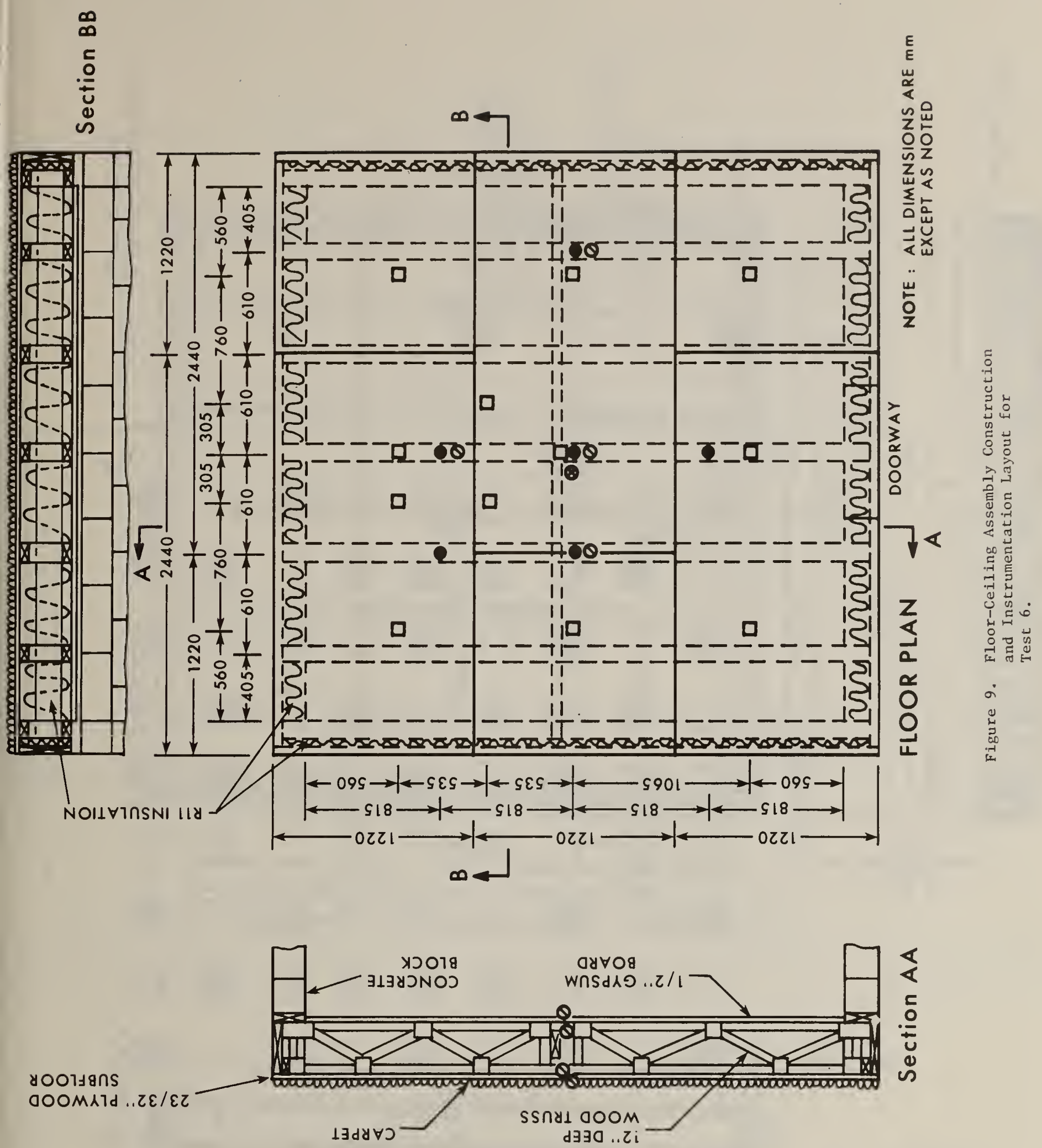


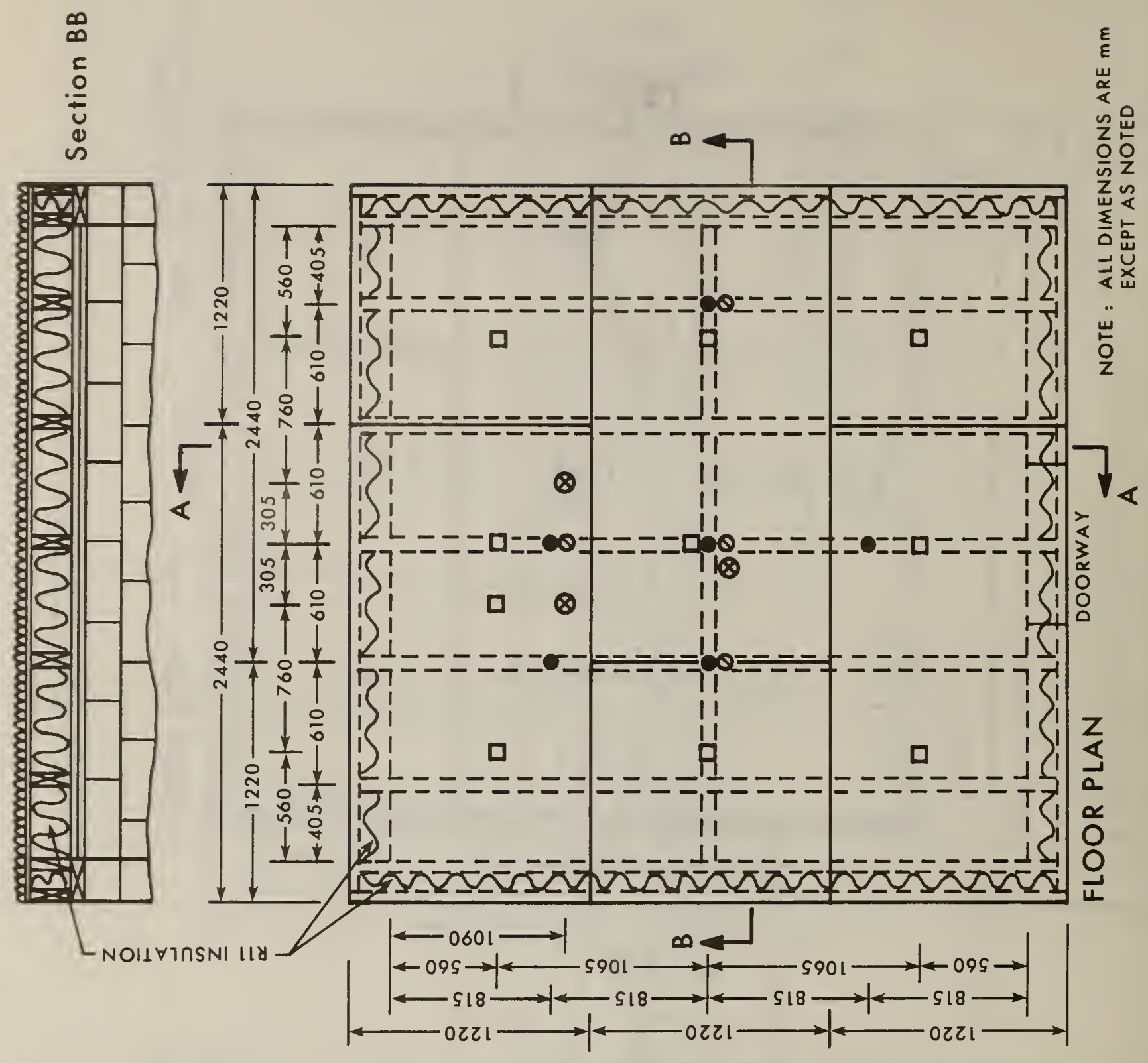

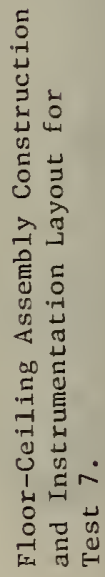

yoolygns

OOOMATd

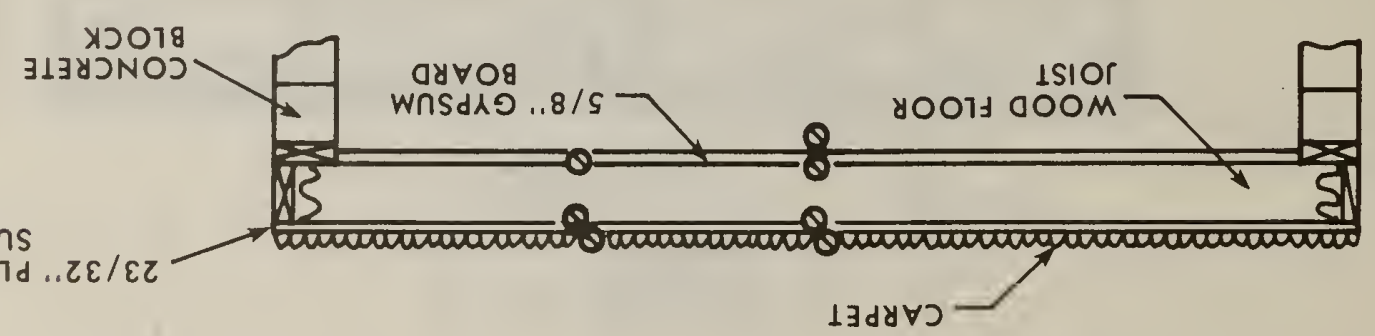

4
$\frac{c}{0}$
$\frac{0}{6}$
0
$\omega$ 
Symbo1

$\square$

0

$\varnothing$

$\otimes$

0

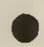

$\nabla$

0

-

0
Type of Transducers

1 Fast Response Thermocouple

3 Thermocouples

2 Fast Response Thermocouples

7 Thermocouples

1 Thermocouple

I Total Heat Flux Gauge

3 Gas Sample Ports

6 Static Pressure Probes

1 Static Pressure Probe

1 Total Heat Flux Gauge
Distance Below the Ceiling (m)

0.61

$0.30,0.61,1.22$

$0.61,1.22$

$0.025,0.15,0.30,0.61$, $1.22,1.70,2.21$

0.61

2.30

$0.36,0.66,1.04$

$0.10,0.30,0.61$,

$1.22,1.70,2.13$

0.10

1.30 


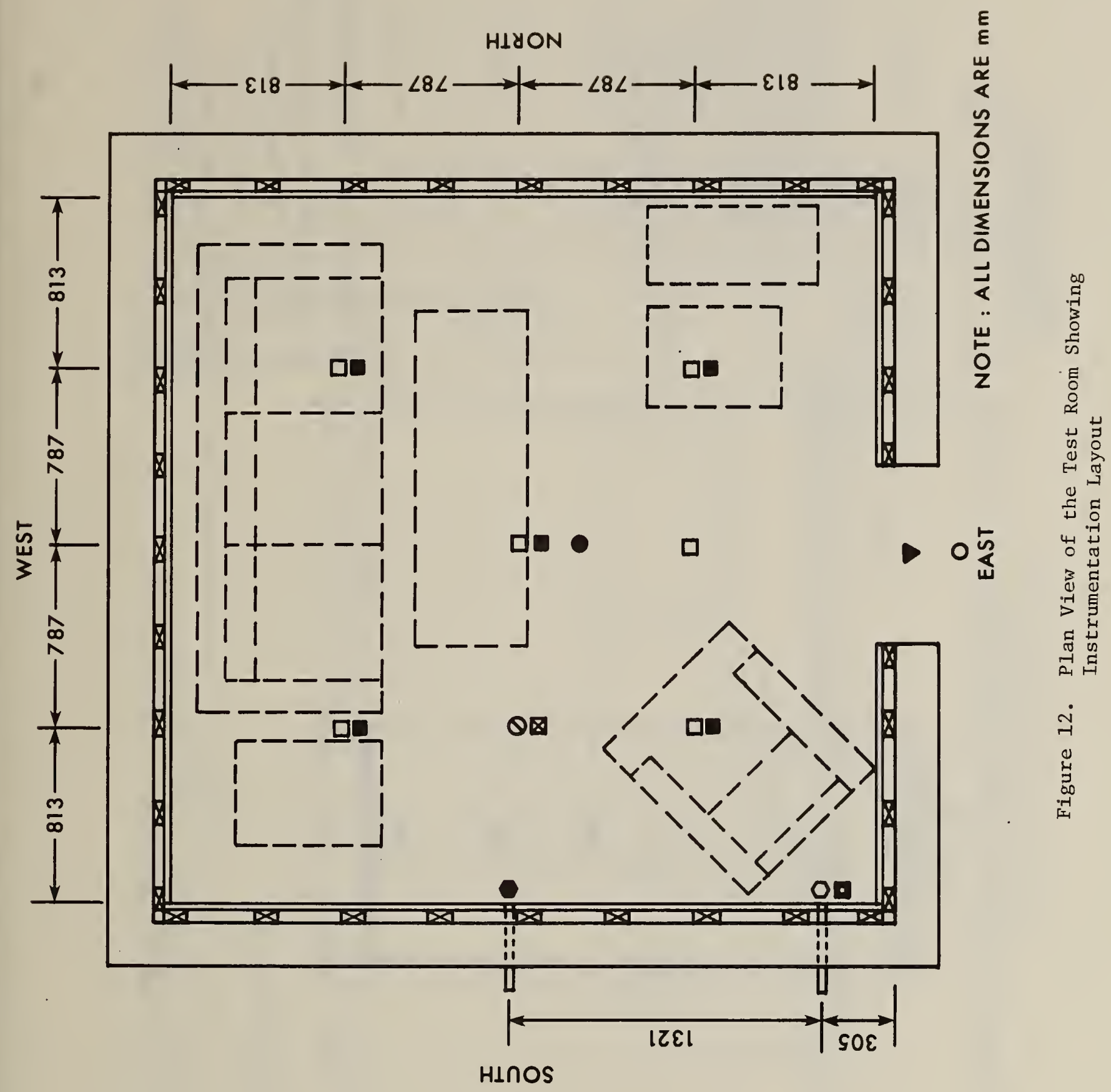



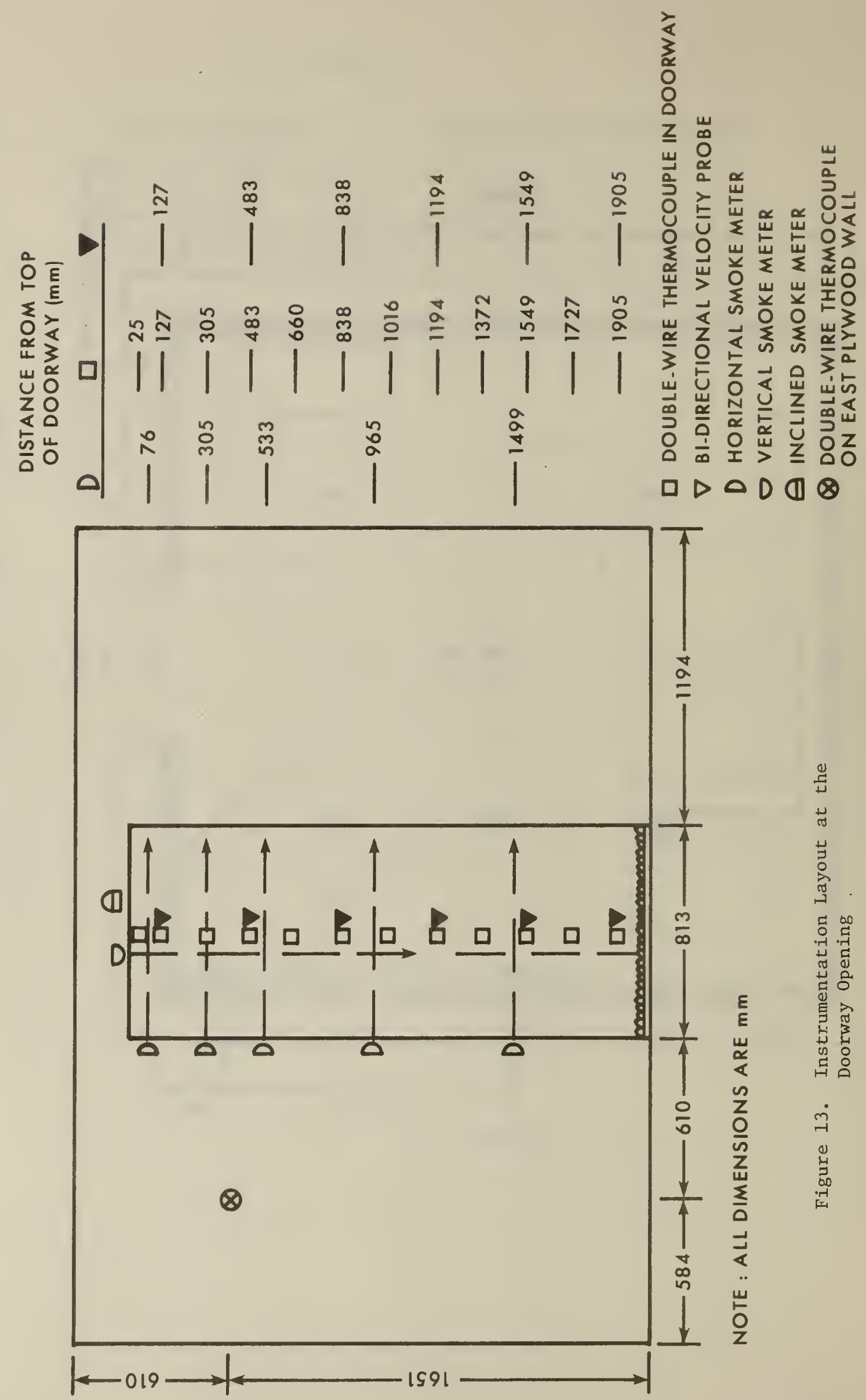


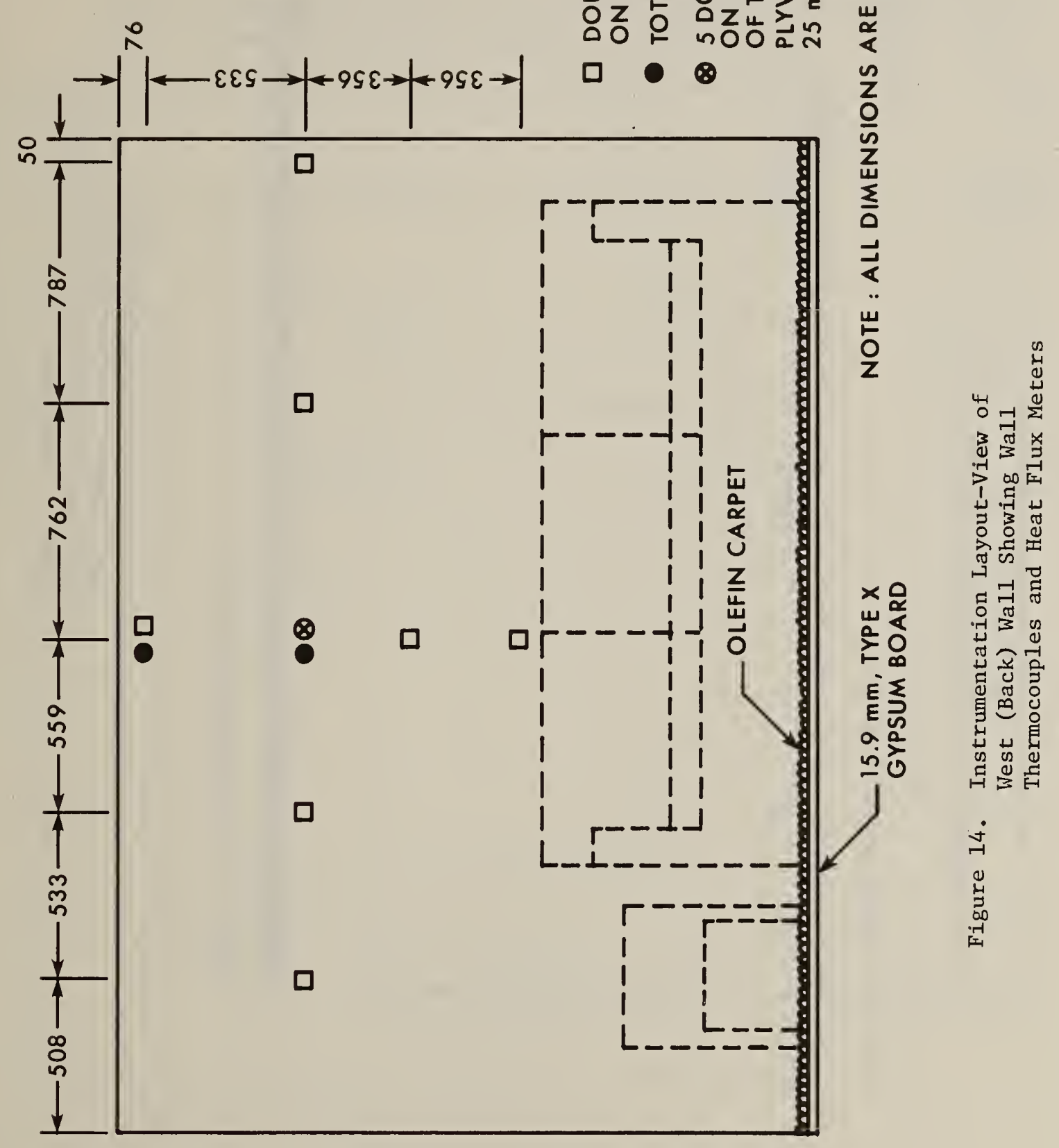




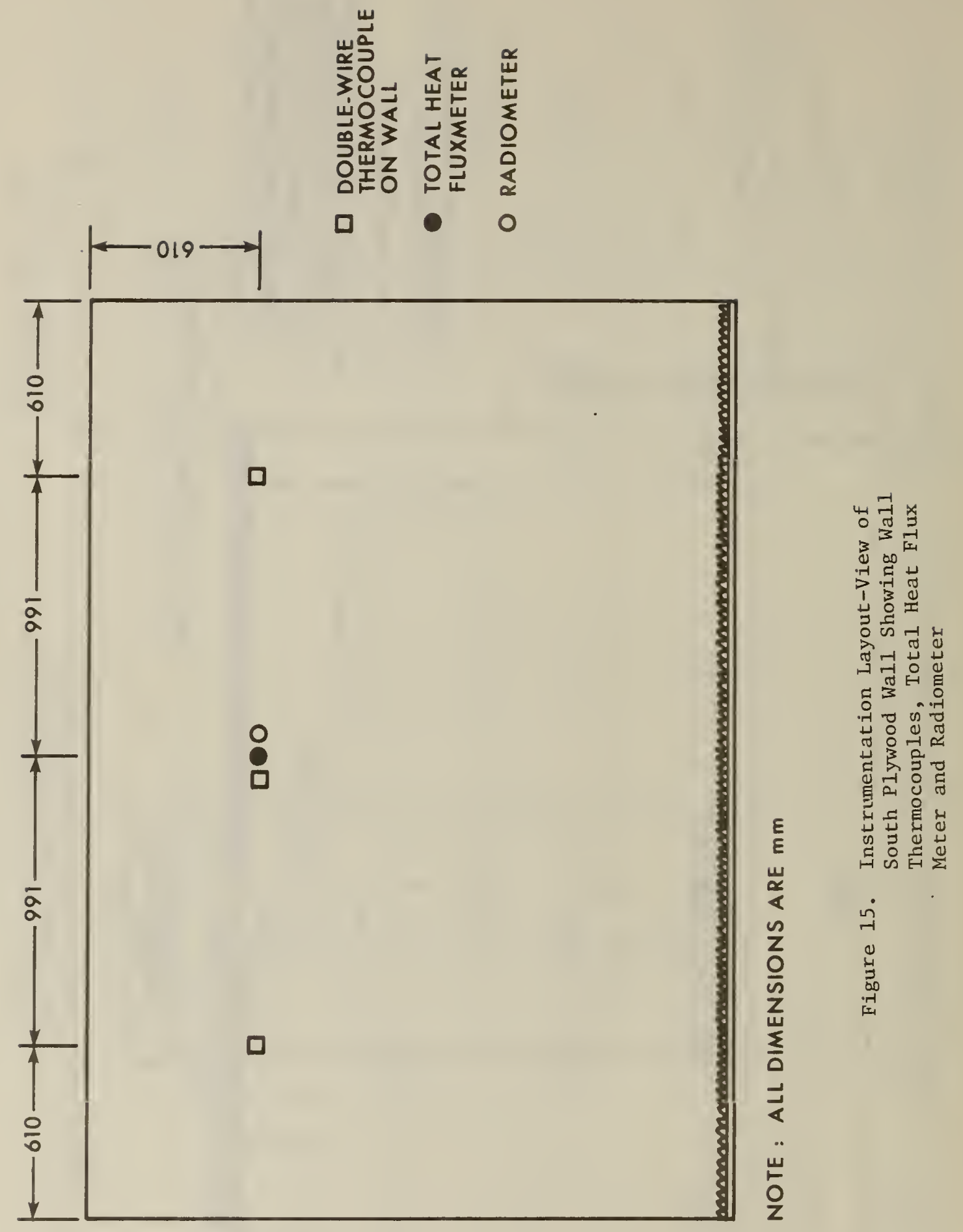




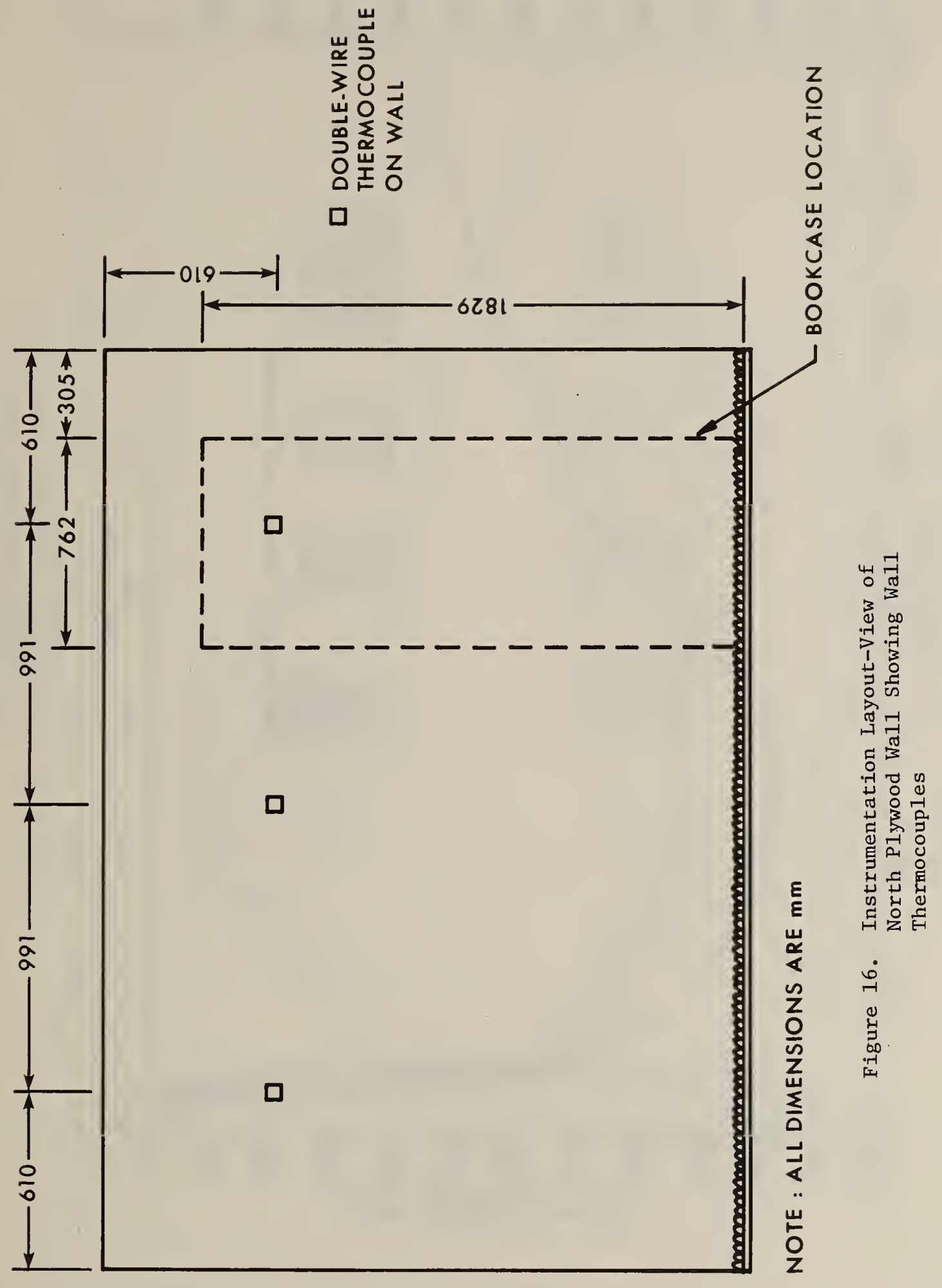




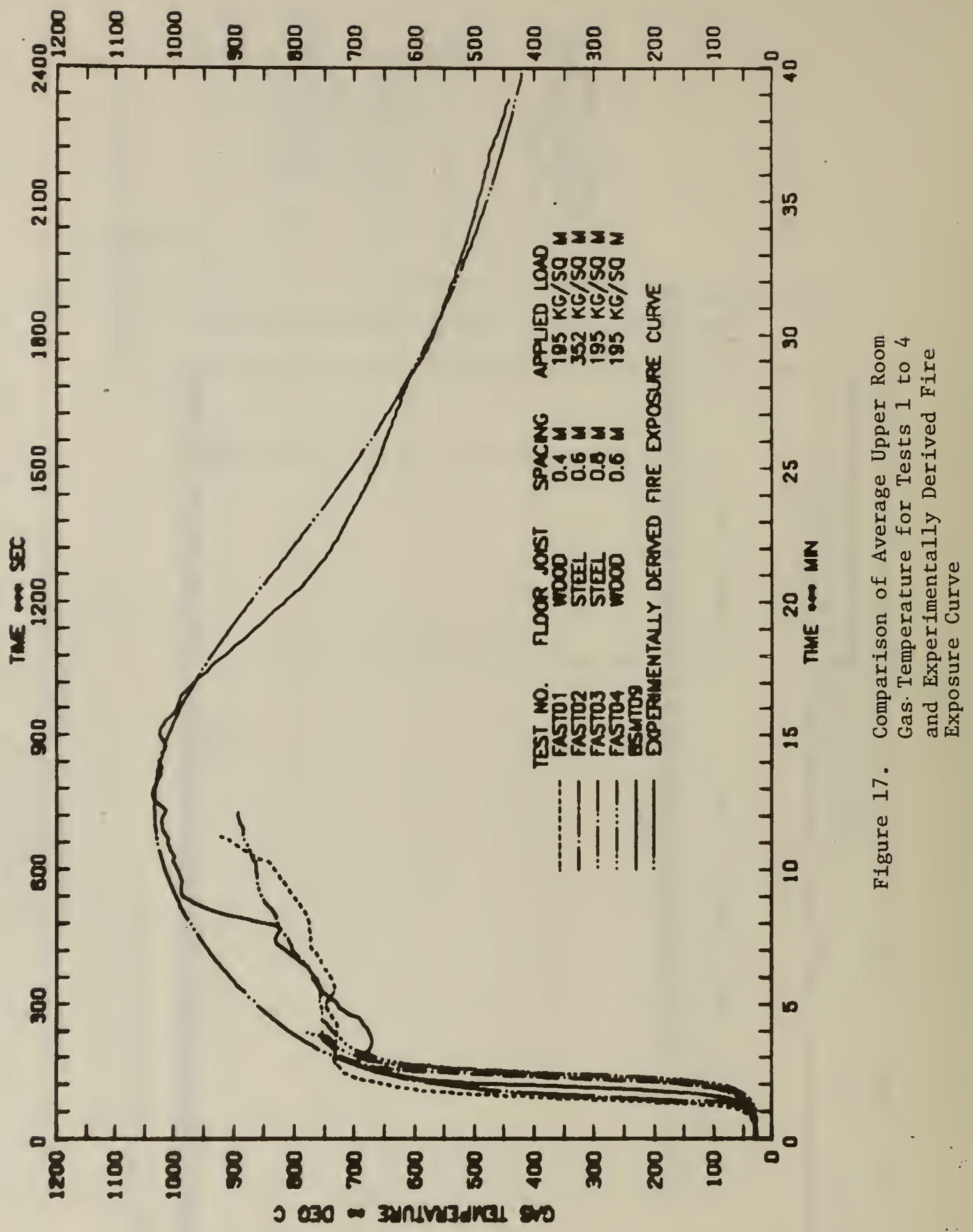




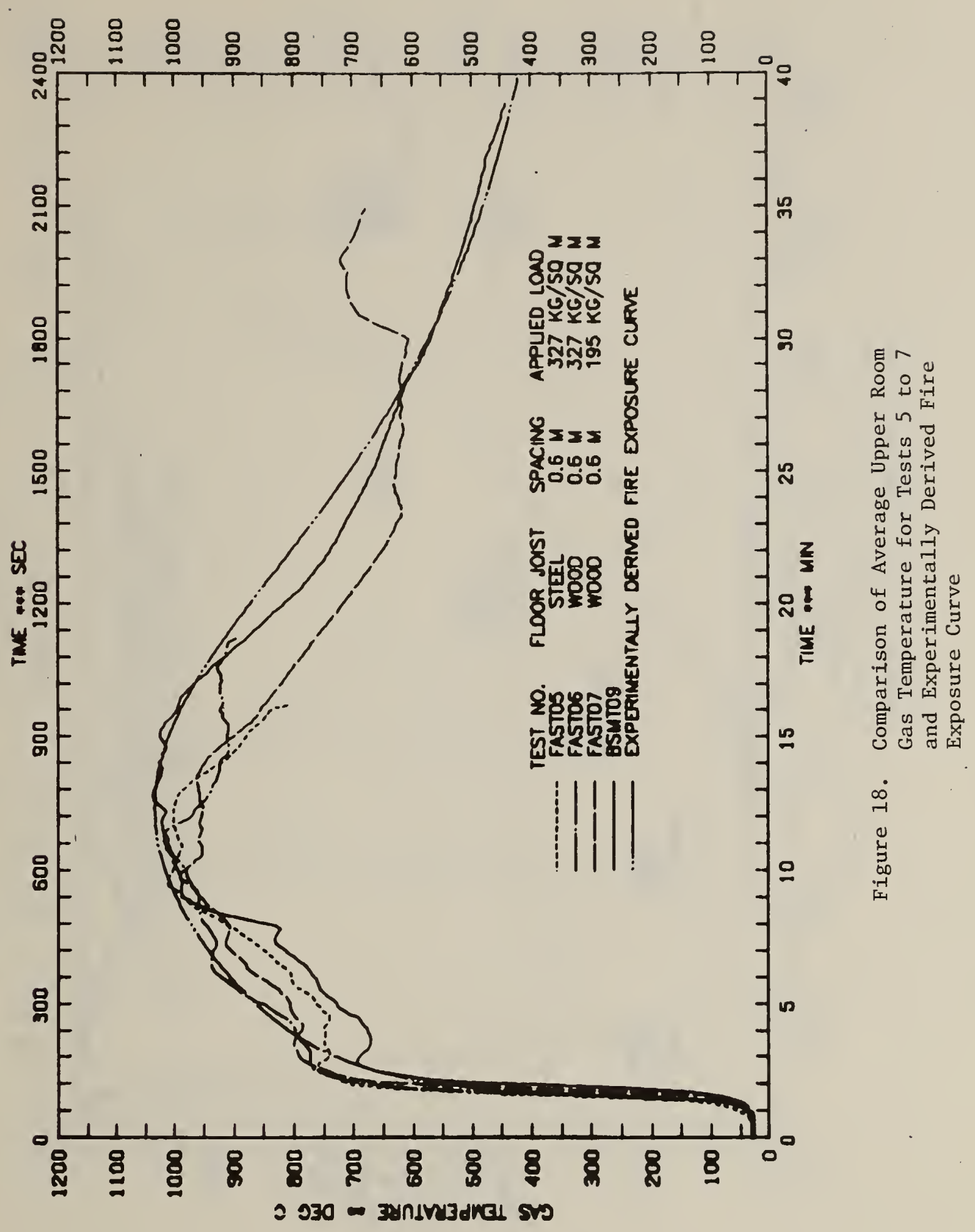




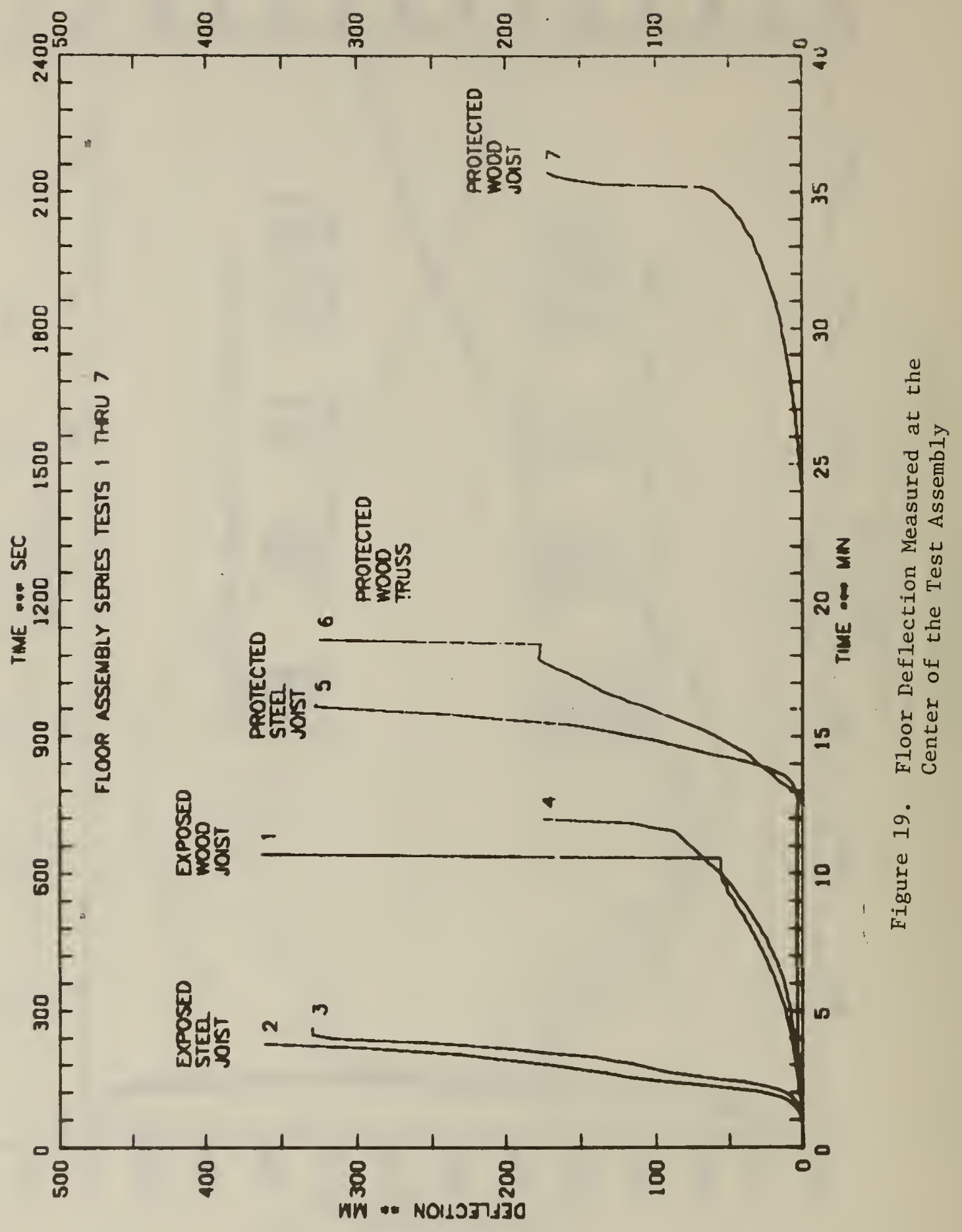




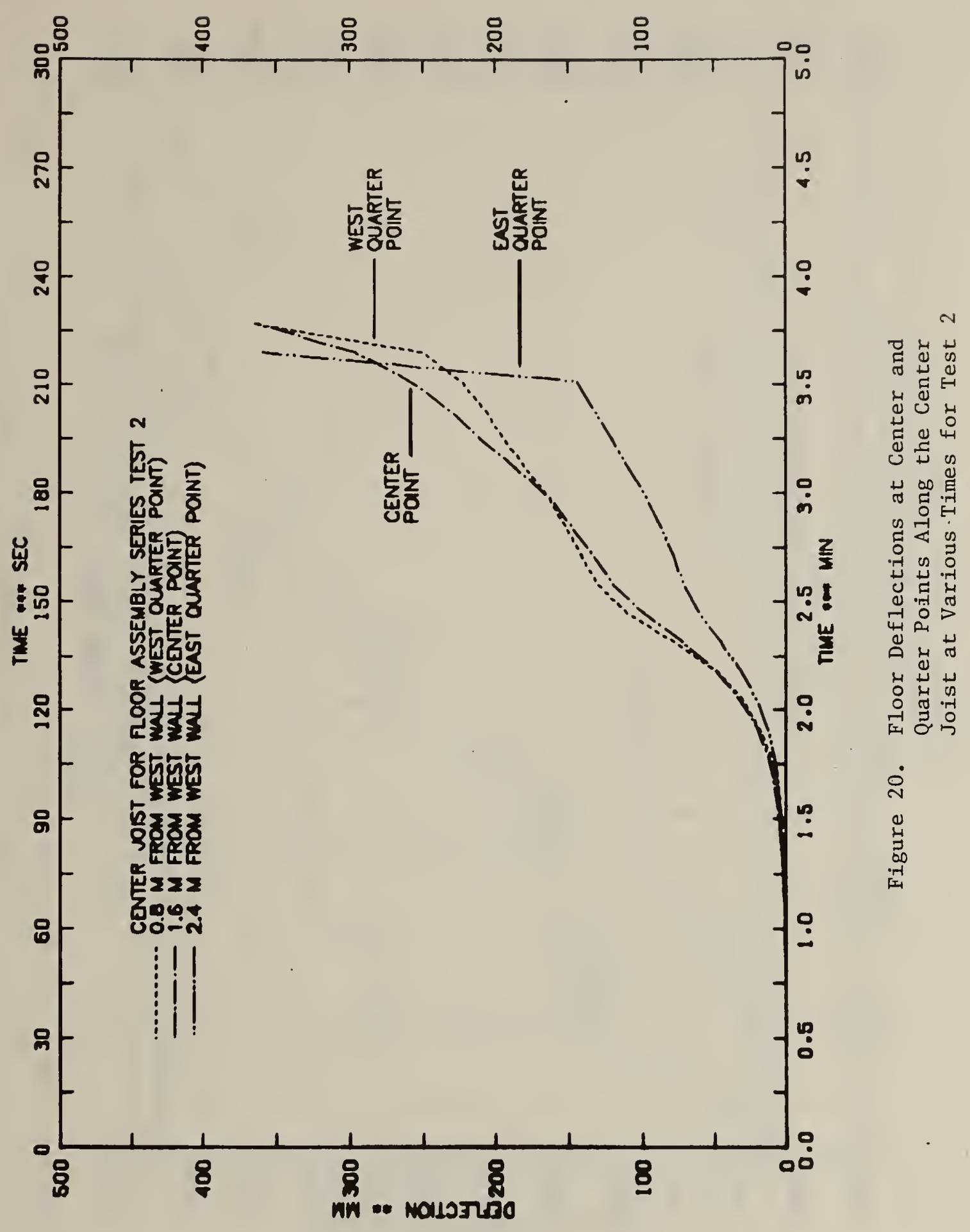




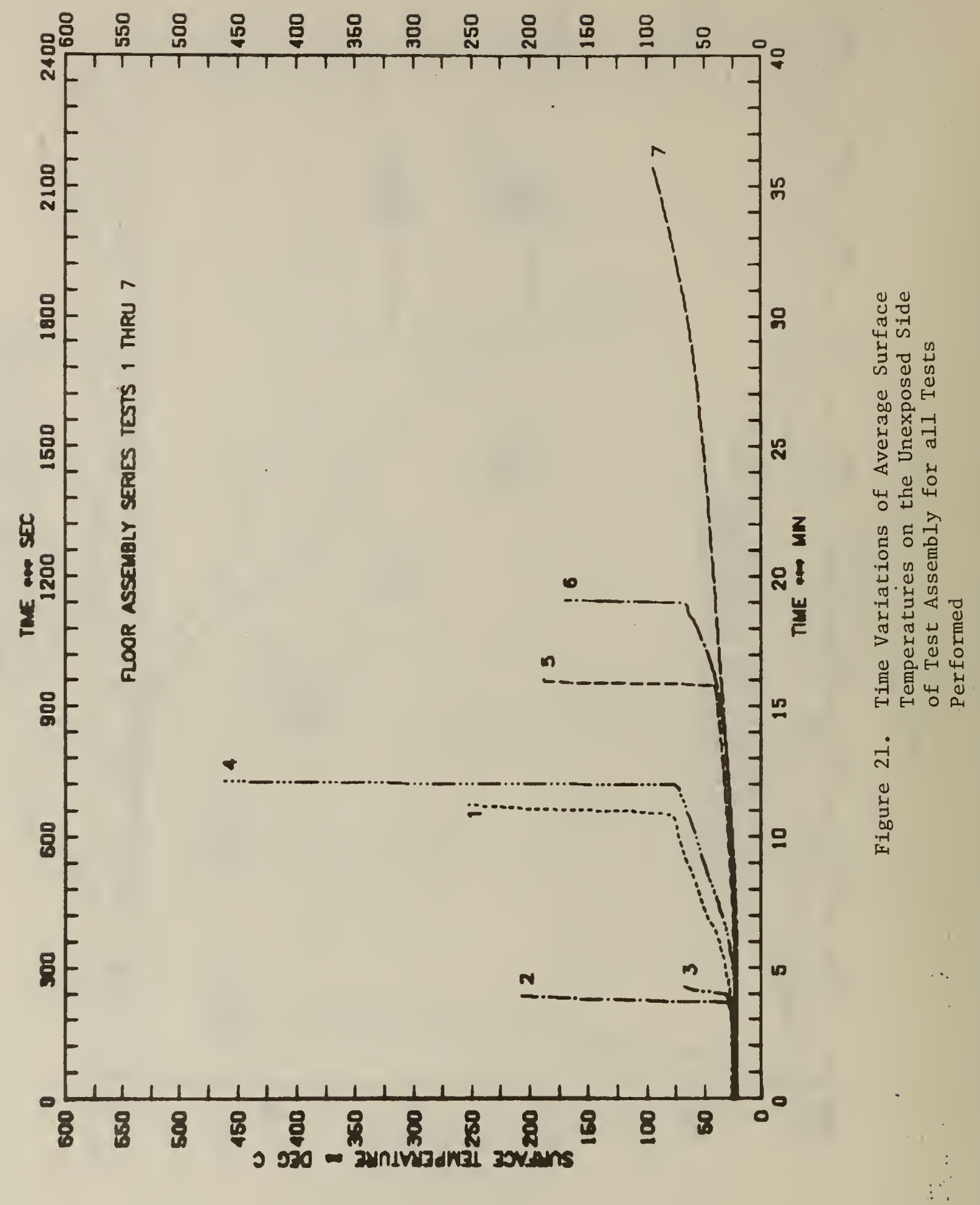




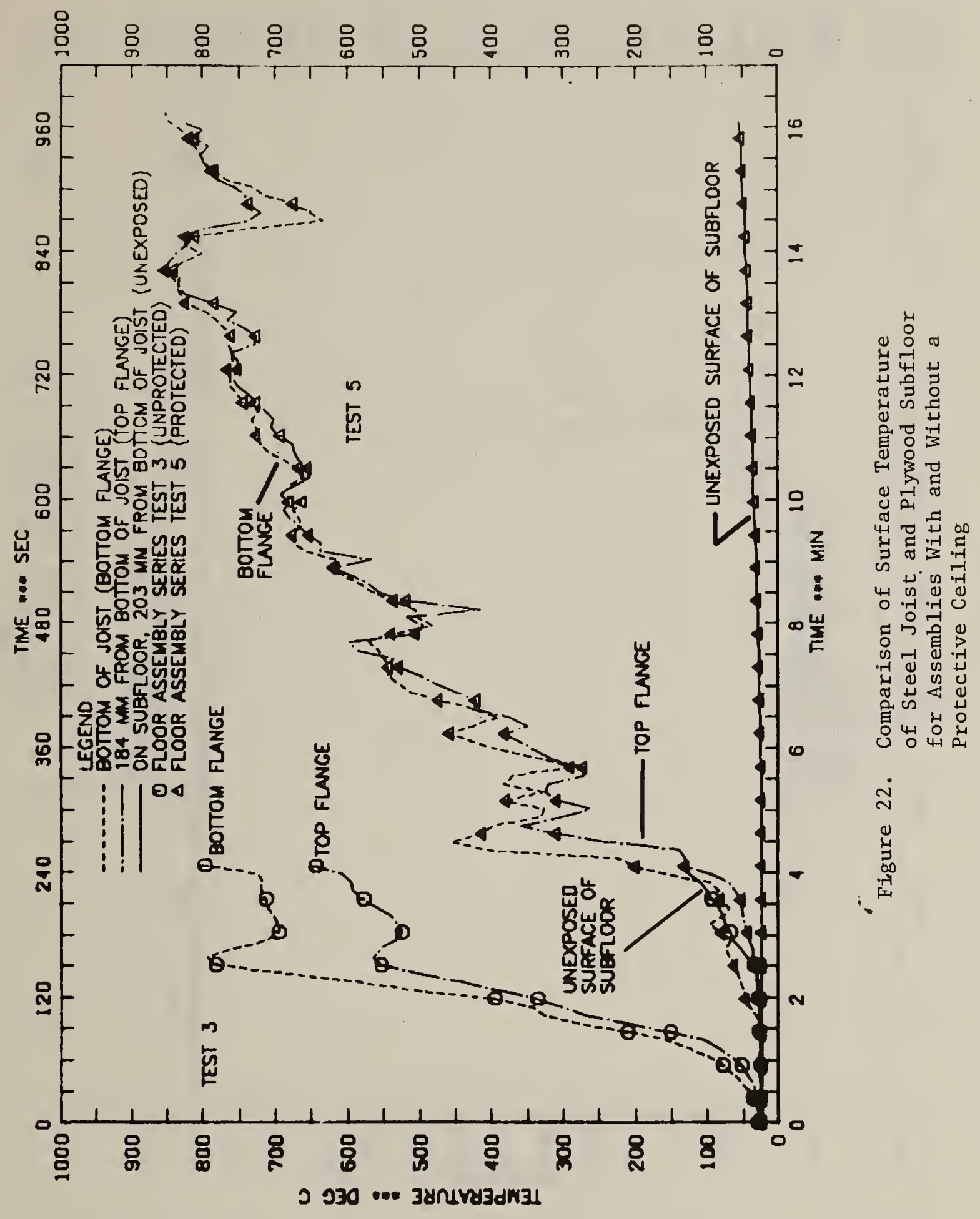




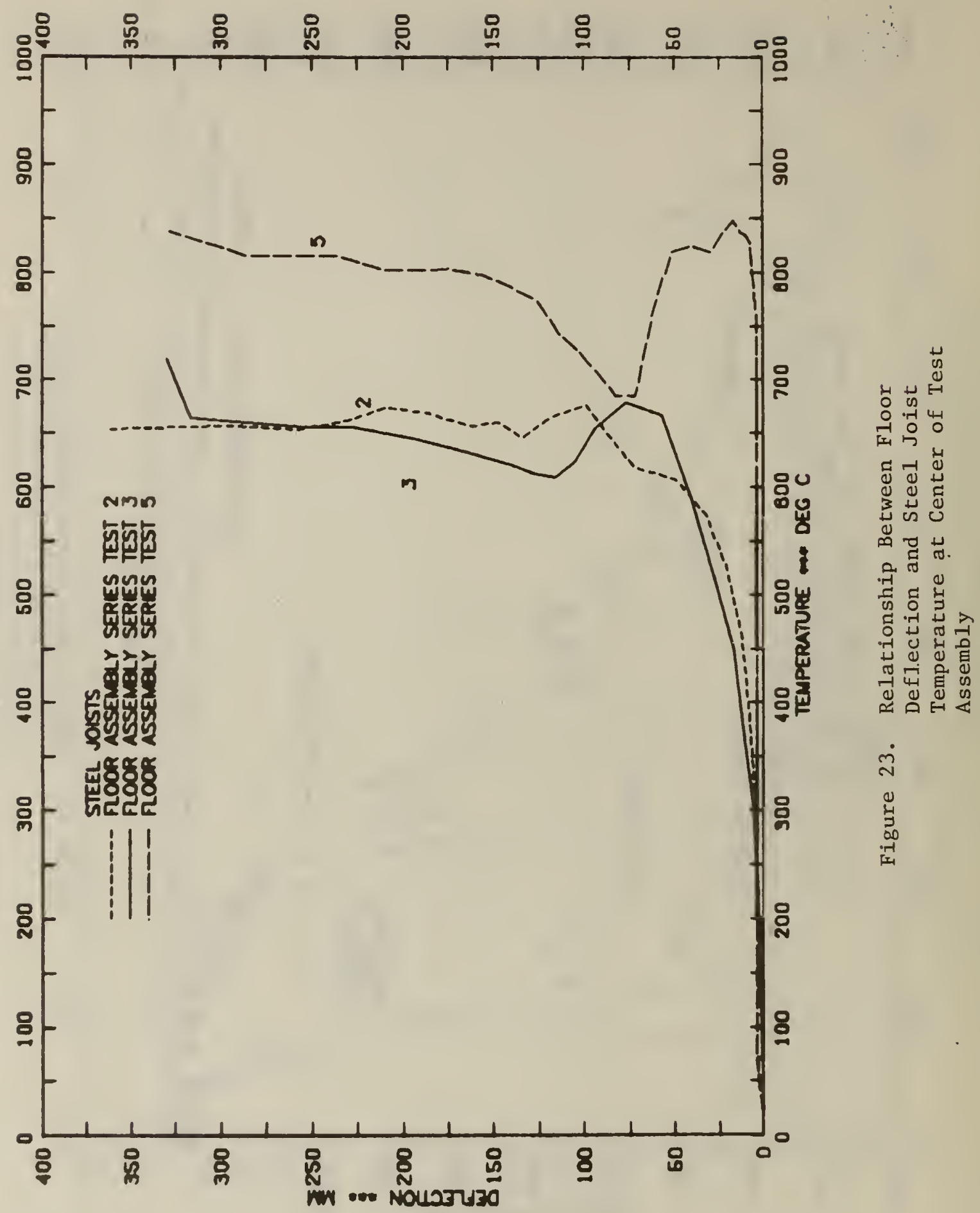




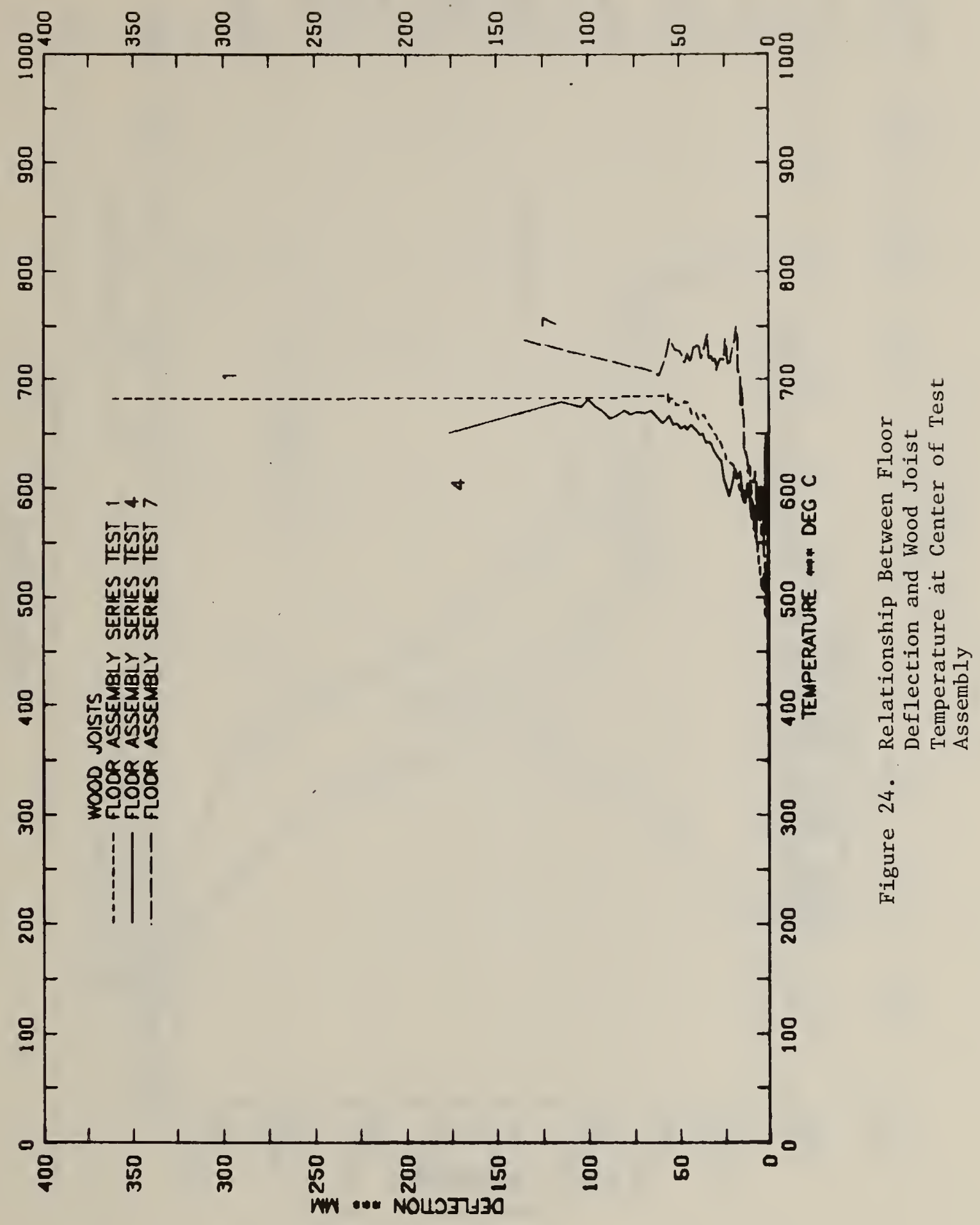




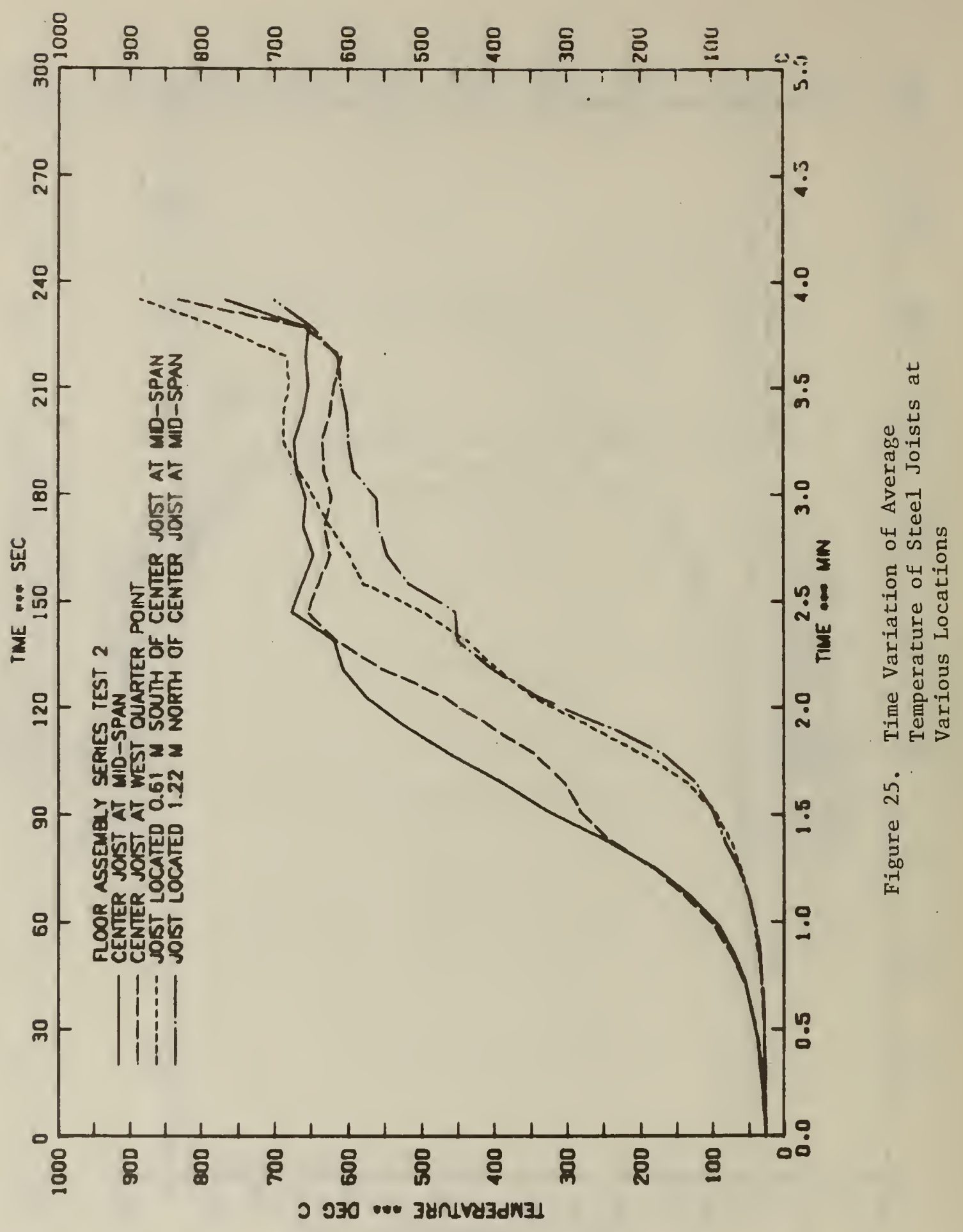




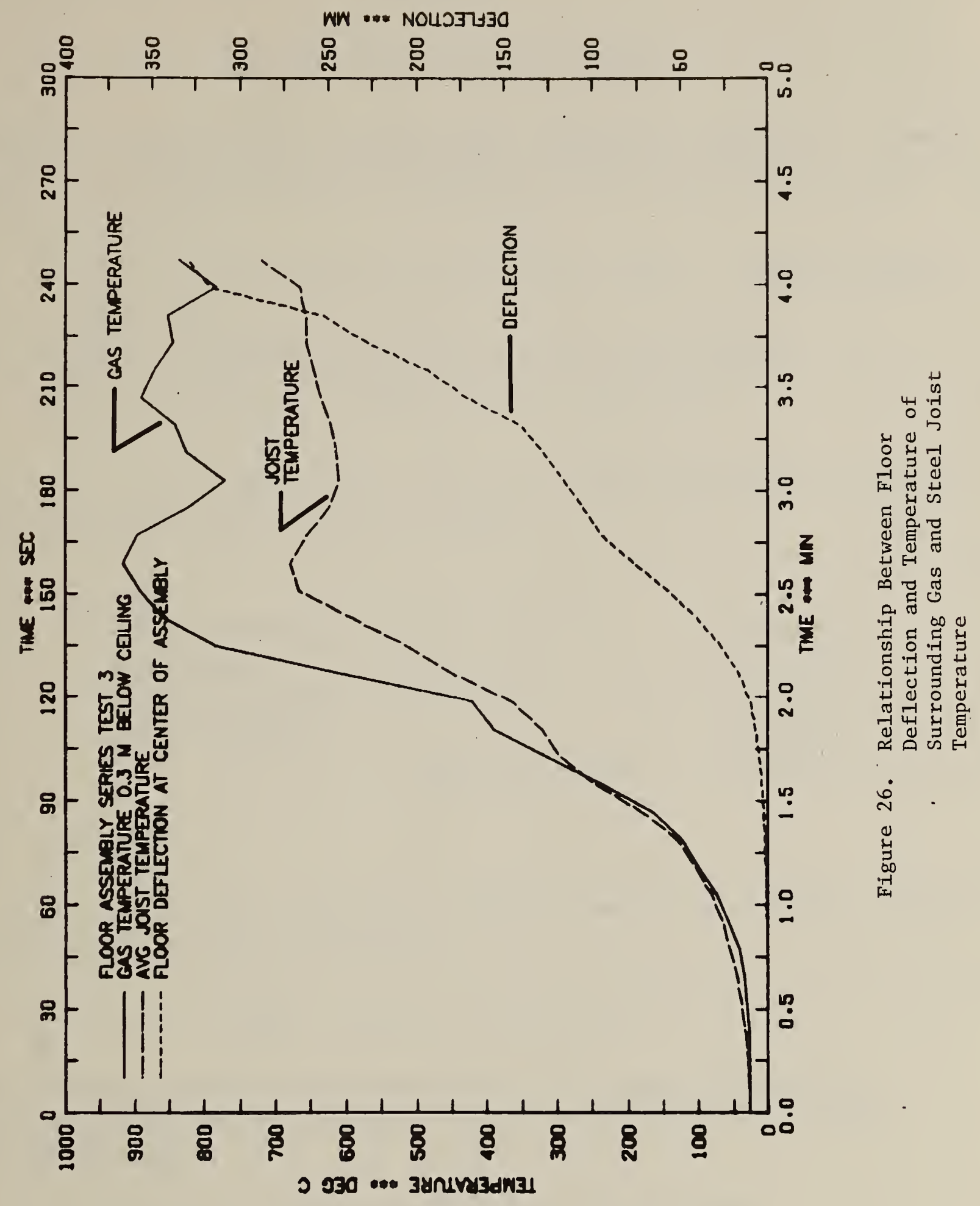



APPENDIX A

\section{Maximum Design Load Calculations}

The design values [6] for Southern pine, construction grade no. 2, medium grain, joists with nominal 51 × $203 \mathrm{~mm}$ ( $2 \times 8$ in) cross section used in test 7 are the following:

allowable bending stress for the extreme fiber, $\mathrm{F}_{\mathrm{b}}=8.27 \times 10^{6} \mathrm{~Pa}$ (1200 psi)

modulus of elasticity, $E=1.1 \times 10^{10} \mathrm{~Pa}\left(1.6 \times 10^{6} \mathrm{psi}\right)$

momert of inertia, $I=1.983 \times 10^{-5} \mathrm{~m}^{4}\left(47.635 \mathrm{in}^{4}\right)$

section modulus, $S=2.153 \times 10^{-4} \mathrm{~m}^{3}\left(13.141 \mathrm{in}^{3}\right)$

The floor joists under uniform loading were simply supported on a $3.25 \mathrm{~m}$ span and spaced $0.61 \mathrm{~m}$ (24 in) on center.

Dead load:

Plywood subfloor (18.3 mm thick)

$9.8 \mathrm{~kg} / \mathrm{m}^{2}$

Wood joists

Gypsum wallboard (15.9 mm thick)

Carpet flooring

Total dead load

$9.8 \mathrm{~kg} / \mathrm{m}^{2}$

$10.7 \mathrm{~kg} / \mathrm{m}^{2}$

$\frac{1.9 \mathrm{~kg} / \mathrm{m}^{2}}{32.2 \mathrm{~kg} / \mathrm{m}^{2}\left(6.6 \mathrm{lb} / \mathrm{ft}^{2}\right)}$

(1) Deflection

A limitation of $1 / 360$ of the span length is used as the maximum allowable total deflection, which is equal to

$$
D=\frac{L}{360}=\frac{3.25}{360}=0.00903 \mathrm{~m}(0.35 \mathrm{in})
$$

The uniform load per unit length on the floor joist corresponding to this maximum deflection, which occurs at the middle of the span can be obtained as

$$
\begin{aligned}
W & =\frac{384}{5} \frac{E I D}{L^{4}}=\frac{(384)\left(1.1 \times 10^{10}\right)\left(1.983 \times 10^{-5}\right)(0.00903)}{(5)(3.25)^{4}} \\
& =1356(\mathrm{~N} / \mathrm{m})=138.3 \mathrm{~kg} / \mathrm{m}(92.8 \mathrm{lb} / \mathrm{ft})
\end{aligned}
$$

and the maximum total allowable load on floor joists with a joist spacing of $0.61 \mathrm{~m}$ on center is 


$$
\text { total allowable load }=138.3 \times 1 / 0.61=227 \mathrm{~kg} / \mathrm{m}^{2}\left(46.5 \mathrm{lb} / \mathrm{ft}^{2}\right)
$$

Therefore, the maximum design load permitted to meet the acceptable deflection is

$$
\begin{aligned}
1 \text { ive load } & =\text { total load }- \text { dead load } \\
& =227-32=195 \mathrm{~kg} / \mathrm{m}^{2}\left(40 \mathrm{lb} / \mathrm{ft}^{2}\right)
\end{aligned}
$$

\section{(2) Bending Moment}

The maximum induced moment occurs at the mid-span of the joist and is equal to the product of the allowable fiber stress in bending and the section modulus of the joist.

$$
M=F_{b} S=\left(8.27 \times 10^{6}\right)\left(2.153 \times 10^{-4}\right)=1781 \mathrm{~N}-\mathrm{m}(15770 \mathrm{in}-1 \mathrm{~b})
$$

The allowable load per unit length on a joist can be calculated as

$$
w=\frac{8 M}{L^{2}}=\frac{(8)(1781)}{(3.25)^{2}}=1349(\mathrm{~N} / \mathrm{m})=137.6 \mathrm{~kg} / \mathrm{m}(92.31 \mathrm{~b} / \mathrm{ft})
$$

The total working load expressed in terms of unit area is equal to

$$
\text { total load }=137.6 \times \frac{1}{0.61}=226 \mathrm{~kg} / \mathrm{m}^{2}\left(46.31 \mathrm{~b} / \mathrm{ft}^{2}\right)
$$

and live load allowed for the maximum bending moment is

$$
\text { live load }=226-32=194 \mathrm{~kg} / \mathrm{m}^{2}\left(39.71 \mathrm{~b} / \mathrm{ft}^{2}\right)
$$

Therefore, the maximum applied load with which the joists are fully stressed to the design value is $195 \mathrm{~kg} / \mathrm{m}^{2}$ (40 psf). 
Time (min:sec)

$0: 10$

$0: 30$

$0: 43$

$0: 45$

$0: 51$

$0: 55$

$1: 00$

$1: 07$

$1: 12$

$1: 22$

$1: 35$

$1: 36$

$1: 40$

$1: 50$

$1: 55$

$2: 02$

$2: 04$

$2: 15$

$2: 17$

$2: 19$

$2: 20$

$2: 40$

$2: 57$

$3: 26$

\section{Events}

Smoke rising from the newspaper on the sofa

Smoke touching ceiling

Smoke is halfway across ceiling

Flame appearance on ignition newspaper

Flames extend to $1.4 \mathrm{~m}$ above seat cushion of sofa

Smoke issuing out doorway

Fire involves center of sofa

Smoke out doorway to $0.8 \mathrm{~m}$ down from the top of doorway

Flame tip located at $0.6-1.0 \mathrm{~m}$ below the ceiling

Flames touching the ceiling

Ignition of carpet

Smoke halfway down in the room

Crackling sound in the room

End cushions split

Portions of the paneling are igniting

Small volumes of flames out doorway

Coffee table ignited

Room flashover occurs (newspaper indicator ignited)

Filter paper indicator ignited

Large flames out doorway

All room contents are burning

Steady state burning

Smoke seeping through joist spaces on floor assembly

Heavy smoking through floor assembly mostly from back part of room 


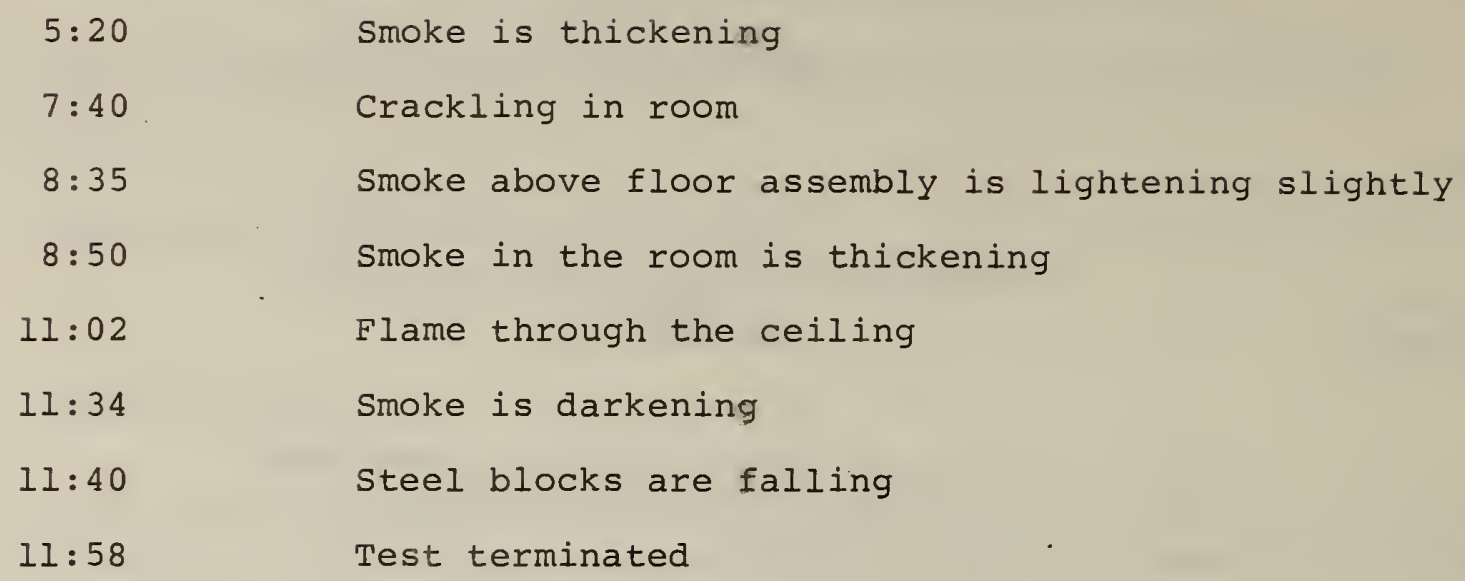

\section{Events}

$0: 04$

$0: 13$

$0: 20$

$0: 24$

$0: 29$

$0: 45$

$0: 50$

I: 07

$1: 11$

$1: 18$

$1: 35$

$1: 39$

$I: 45$

$1: 50$

$1: 54$

$1: 59$
Light smoke rising from the ignition newspaper Flames appear on the newspaper

Flames to $0.8 \mathrm{~m}$ above seat cushion of the sofa Center of sofa is burning Flames to $1.1 \mathrm{~m}$ above the central seat cushion Flames to $1.4 \mathrm{~m}$ above sofa seat cushion light smoke in top portion of room Flame spread on sofa center about $0.4 \mathrm{~m}$ in width Flames sporadically touching the ceiling Flames spreading along ceiling surface Cushions are smoldering Flames halfway across the ceiling Left arm of sofa is smoking Flames across entire ceiling Smoke layer halfway down from ceiling Flames involving about $3 / 4$ of sofa B-2 


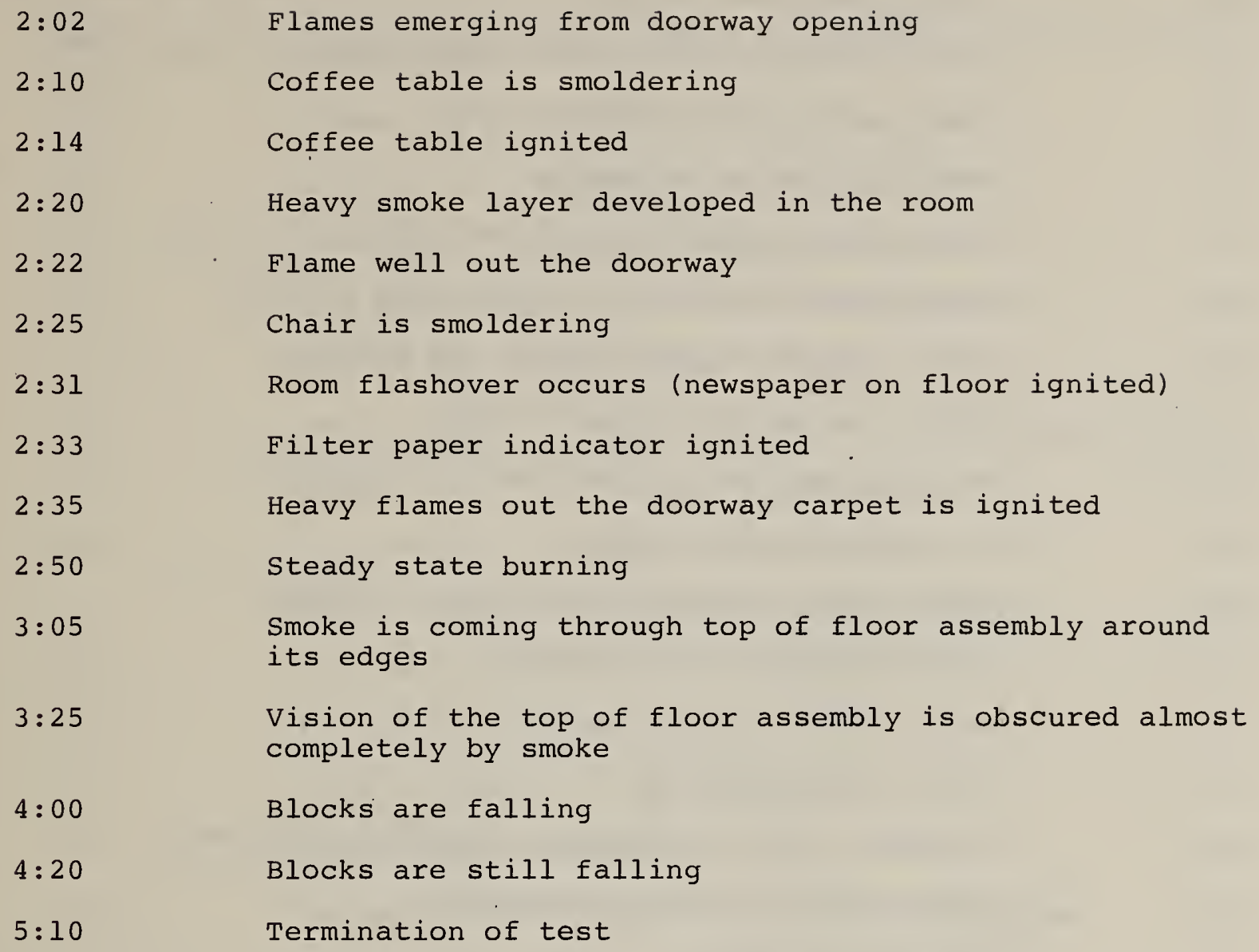

\section{Events}

Smoke rising from center of ignition newspaper

Flames on sofa extend to $0.6 \mathrm{~m}$ above central seat cushion of the sofa

Flames to $0.8 \mathrm{~m}$ above the seat cushion 
$0: 47$

$0: 54$

$1: 00$

$1: 10$

$1: 12$

$1: 19$

$1: 35$

$1: 42$

$1: 52$

$1: 59$

$2: 09$

$2: 10$

$2: 15$

$2: 20$

$2: 28$

$2: 30$

$2: 39$

$2: 45$

$3: 00$

$4: 07$

$4: 14$

$4: 32$

TEST 4

Time (min:sec)

$0: 04$

$0: 08$
Flames fluctuate between 1.4 to $1.7 \mathrm{~m}$ above the seat cushion

Flames covering $1 / 2$ of the center cushion of the sofa

Flames are touching the ceiling

Smoke in room is darkening

Flames are spreading along the top of the sofa

Smoke layer down to $0.6 \mathrm{~m}$ below the ceiling

Flames extend halfway across the ceiling

Flames are covering the ceiling.

The end cushions of the sofa are splitting

The end cushions ignited

Smoke layer extends halfway down to floor

Flames emerging from doorway

Heavy flames out the doorway

Coffee table ignites

Flashover occurs (newspaper indicater ignited)

Filter paper indicator inflames

Carpet is ignited

steady state burning

Heavy smoke coming through back of the top of test assembly

Flames penetrate through the floor assembly

Floor assembly collapses

Test terminated

\section{Events}

Light white smoke given off from the ignition newspaper

Flames appear behind the newspaper 
$0: 21$

$0: 45$

$0: 51$

$1: 13$

$1: 18$

$1: 24$

$1: 29$

$1: 50$

$1: 55$

$2: 01$

$2: 07$

$2: 13$

$2: 15$

$2: 18$

$2: 22$

$2: 25$

$2: 26$

$2: 39$

$2: 44$

$2: 45$

$3: 03$

$4: 14$

$5: 15$

$5: 24$

$6: 30$

$10: 05$

$11: 09$
The back of sofa is burning; flames to $0.83 \mathrm{~m}$ above seat cushion

Flame tip to $1.2 \mathrm{~m}$ above seat cushion

Flames to $1.5 \mathrm{~m}$ above the cushion

Flames to $1.8 \mathrm{~m}$ above seat cushion

The upper part of the room is darkening

Flames are touching the ceiling

Smoke layer is filling the upper half of the room

Flames cover $3 / 4$ of the ceiling area

End cushions of sofa are splitting

Flames emerging from the doorway opening

Entire top of the sofa is burning

End cushions are burning

Flames extend $1 \mathrm{~m}$ out doorway

Coffee table is burning

Newspaper flashover indicator is smoldering

Heavy smoke down to $0.5 \mathrm{~m}$ above the floor

Room flashover occurs (newspaper indicator ignited)

Filterpaper indicator ignited spontaneously and carpet is ignited

Heavy flames issue out the doorway

All combustible materials in the room are burning

Most of the smoke passing through the floor assembly are coming from the doorway side

Smoke above the rear portion of the assembly is thickening

Top of the room is almost obscured from view by smoke

Slight increase in smoke density is observed for top of the room

Smoke density is decreasing

Smoke is darkening slightly

Smoke is getting lighter 
$11: 50$

$12: 08$

$12: 10$

$12: 16$

TEST 5

Time

$\underline{\text { (min:sec) }}$

$0: 03$

$0: 10$

$0: 13$

$0: 20$

$0: 31$

$0: 37$

$0: 40$

$0: 41$

$0: 49$

$0: 52$

$1: 02$

$1: 14$

$1: 20$

$1: 25$

$1: 32$

$1: 35$

$1: 37$

$1: 41$

$1: 45$
Smoke density is decreasing

Floor assembly collapses

Flames pass through floor assembly

Test terminated

\section{Events}

Light smoke appears from the ignition newspaper

Flame appearance on the newspaper

Flame height $0.8 \mathrm{~m}$ above central seat cushion of sofa

Flames to $1.1 \mathrm{~m}$ above the seat cushion

Top of central cushion involved in burning

Light smoke is coming out the doorway opening

Flame tip locate at $1.7 \mathrm{~m}$ above sofa seat cushion

Flames touch the ceiling occasionally

Flames are touching the ceiling

Black smoke starts to fill the room from the ceiling

Black smoke fills the upper half of the room

Flames begin to turn around the back corner onto the ceiling

End cushions of sofa are splitting

Flame extends halfway across the ceiling

Flames cover three-fourths of the ceiling area

Black smoke layer is still at halfway down from ceiling

End cushions of sofa are burning

Flames emerging from the doorway opening

Coffee table is burning 


\begin{tabular}{|c|c|}
\hline $1: 54$ & Room flashover takes place (newspaper indicator ignited) \\
\hline $1: 55$ & Filterpaper indicator ignited \\
\hline $1: 56$ & Heavy flames coming out the doorway \\
\hline $2: 08$ & Chair is burning \\
\hline $2: 10$ & Carpet on floor is curling up \\
\hline $2: 11$ & Carpet is burning \\
\hline $2: 12$ & Steady state burning \\
\hline $3: 40$ & $\begin{array}{l}\text { Light smoke is coming out from the cracks between the } \\
\text { floor assembly and concrete block walls }\end{array}$ \\
\hline $6: 30$ & $\begin{array}{l}\text { Smoke is coming out of test assembly at nearly constant } \\
\text { rate }\end{array}$ \\
\hline $8: 40$ & No appreciable co reading in the vicinity of test room \\
\hline$: 45$ & Zero co reading \\
\hline$: 57$ & co $4 \mathrm{ppm}$ in the area near test room \\
\hline$: 19$ & $\begin{array}{l}\text { Small pieces of gypsum board ceiling start falling down } \\
\text { onto the floor }\end{array}$ \\
\hline : 54 & Large pieces of gypsum board drop down \\
\hline$: 15$ & Large fragments of ceiling materials fall down \\
\hline 08 & Wood framing of the sofa collapse \\
\hline$: 08$ & $\begin{array}{l}\text { Passage of flames through center of test assembly occurs } \\
\text { Test terminated }\end{array}$ \\
\hline
\end{tabular}

\section{TEST 6}

\section{Events}

$0: 04$

$0: 06$

$0: 10$

$0: 16$
Light smoke rising from the back of the ignition newspaper Sustained flaming of the newspaper

Flame is spreading across the top of the newspaper Flames are traveling up the back cushion of the sofa 
$0: 20$

$0: 35$

$0: 38$

$0: 43$

$0: 53$

$1: 02$

$1: 08$

$1: 13$

$1: 20$

$1: 22$

$1: 23$

$1: 30$

$1: 32$

$1: 40$

$1: 42$

$1: 43$

$1: 45$

$1: 49$

$1: 52$

$2: 25$

$11: 10$

$11: 43$

$11: 57$

$12: 20$

$13: 35$

$14: 25$

$15: 00$

$15: 12$

$16: 25$
Flames extend to $1.1 \mathrm{~m}$ above the sofa seat cushion

Flames to $1.4 \mathrm{~m}$ above seat cushion

Flames to $1.7 \mathrm{~m}$ above seat cushion

Flames touch ceiling

Flames concentrated on center cushion of sofa

Smoke in the room is darkening

Flames extend $1 / 3$ way across the ceiling

Sofa arms are melting

End cushions of sofa are burning

Smoke in the upper part of the room is thickening

Flames halfway across the ceiling

Flames emerging from the doorway opening

Coffee table is burning

Heavy smoke issuing out the doorway

The entire sofa is burning

Room flashover occurs (newspaper indicator ignited)

Filterpaper indicator ignited spontaneously

Steady state burning

Carpet is curling up

Carpet ignited

Light smoke coming through the floor assembly

South block wall is cracking

Smoke coming out of cracks in west and south block walls Pieces of gypsum board ceiling are falling

More pieces of ceiling materials drop down

Test assembly starts deflecting

Deflection is increasing

Smoke has obscured the view of weights on floor assembly

Fragments of wood truss fall and burn on floor

Smoke is very dense 
$17: 03$

$17: 52$

$17: 59$

$18: 54$

TEST 7

T'ime

$\underline{\text { (min:sec) }}$

$0: 05$

$0: 10$

$0: 15$

$0: 22$

$0: 25$

$0: 35$

$0: 43$

$0: 52$

1:02

$1: 20$

$1: 27$

$1: 30$

$1: 37$

$1: 46$

$1: 47$

$1: 51$

$1: 52$

$2: 03$
Crackling sounds in the back of the room

Flames pass through the rim joist resting on the rear block wall and the centrally located wood truss collapses

Flame through the floor assembly in back of room

Test terminated

\section{Events}

Light smoke rises from the ignition newspaper

Visible flames appear on the newspaper

Flame spread across the top of the newspaper

The back cushion of the sofa is burning

Flame tip reaches $0.8 \mathrm{~m}$ above the seat cushion of sofa

Flame height $1.1 \mathrm{~m}$ above the sofa seat cushion

Flames to $1.4 \mathrm{~m}$ above the seat cushion

Flame height $1.7 \mathrm{~m}$ above the seat cushion

Flames are touching the ceiling

Dark smoky layer located above the mid height of room ceiling

Ceiling flame extends to one-half way across ceiling

Seat cushions at both ends of the sofa split open and expose inner foam

The entire sofa is involved in burning

Smoky flames emerge from the aoorway

Coffee and end tables ignited spontaneously

Room flashover occurs (newspaper indicator ignited)

Filter paper indicator ignited

Steady state burning 
$2: 08$

$3: 05$

$9: 45$

$13: 25$

$15: 00$

$18: 45$

$19: 00$

$19: 55$

$23: 16$

$23: 43$

$24: 50$

$25: 30$

$26: 35$

$27: 05$

$28: 15$

$29: 45$

$31: 00$

$34: 50$

$35: 21$

$35: 26$
Carpet is curling up and ignited

Light smoke is coming out through south block wall near heat flux-meter location

Cracks develop in south and west block walls

Cracking of block walls continues

Furring strips attached to block walls burn actively

Co level in the vicinity of test room $9 \mathrm{ppm}$

Gypsum board ceiling still intact

Fire has died down considerably

Small piece of ceiling material falls off from gypsum ceiling near doorway

Flames emerge from doorway once again

Room gas temperature shows a slight increase; the central portion of gypsum board ceiling falls off

Another piece of ceiling falls off

Burning of floor assembly continues and room gas temperature rises continuously

Floor is deflecting significantly

Rapid temperature rise on unexposes surface of test assembly

Floor deflections are increasing

Heavy flames come out doorway

Both deflection and unexposed surface temperature are rising continuously

Flames through floor assembly at the location adjacent to the ceiling above the bookcase

Test terminated 
NBS-114A IR:V. Q-7B)

\begin{tabular}{|c|c|c|}
\hline $\begin{array}{l}\text { U.S. DEFT. OF COMM. } \\
\text { BIBLIOGRAPHIC DATA } \\
\text { SHEET }\end{array}$ & \begin{tabular}{|c|c|} 
1. PUELICATION OR RE WORT NO. & 2.Gov't. Accession No. \\
NBS IR $80-2134$ &
\end{tabular} & 3. Recipient's Accession No. \\
\hline $\begin{array}{l}\text { 4. TITLE ANO SUBTITLE } \\
\text { Fire Performance } \\
\text { Constructions Und }\end{array}$ & $\begin{array}{l}\text { Selected Residential Floor } \\
\text { er Room Burnout Conditions }\end{array}$ & 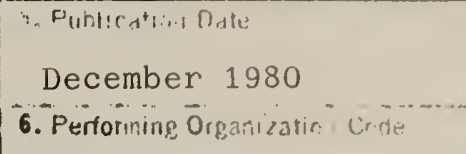 \\
\hline $\begin{array}{l}\text { 7. Alitiok st } \\
\text { Jin Buo Fang }\end{array}$ & & 8. Performing $(i$, \\
\hline $\begin{array}{l}\text { 9. F ORMINC ORGANIZATI } \\
\text { NATIONAL BUREAU OF } \\
\text { DEPARTMENT OF COMM } \\
\text { WASHINGTON, DC } 20234\end{array}$ & $\begin{array}{l}\text { N NAME AND ADDRESS } \\
\text { ETANDARDS } \\
\text { ERCE }\end{array}$ & 10. Project/Task/Work Unit No. \\
\hline $\begin{array}{l}\text { 12. SPONSORING ORGANIZATI } \\
\text { Division of Energ } \\
\text { Office of Policy } \\
\text { U.S. Department o } \\
\text { Washington, D.C. }\end{array}$ & $\begin{array}{l}\text { N NAME AND COMPLETE ADORESS (streel, City, state, ZIP) } \\
\text {, Building Technology and Standards } \\
\text { development and Research } \\
\text { Housing and Urban Development } \\
20410\end{array}$ & $\begin{array}{l}\text { 13. Type of Repori ix Perioul Covered } \\
\qquad \text { Inter im }\end{array}$ \\
\hline
\end{tabular}

15. SUPPLEMENTARY NOTES

I Locument describes a computer program; SF-185, FIPS Sortware Summary, is attached.

15. ABSTRACT (A 2Ud-wurd or less tactual summary of mast significant information. If document includes a significant bibliugrupliy if (1) stature survey, merition there.)

A series of seven large-scale room burnout fire tests was conducted with a set of selected residential floor-ceiling assemblies to provide data on the performance of the assemblies; these will be compared with the results in future tests on the same constructions in a fire endurance furnace. Four wood-frame and three light gage steel-frame, load-bearing assemblies, each measuring $3.7 \mathrm{x} 3.7 \mathrm{~m}$ in size, were exposed from the underside to a fire environment produced from the burning of typical furniture and interior finish materials in a room. The fire resistance periods baced on flame-through of floor assembly and structural failure of floor joists varied from 10 to 12 minutes for floors with unprotected wood joists and was 4 minutes or less for floors with unprotected steel joists. The addition of a $12.7 \mathrm{~mm}$ thick gypsum board ceiling as a protective layer increased the fire resistance time of the steel joisted floor assembly approximately 12 minutes.

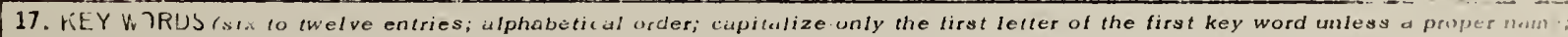
repirited by semicuions)

Fire endurance; fire tests; flame through; floors; furniture; interior finishes; joists; room fires; steel; wood.

\begin{tabular}{|c|c|c|}
\hline 18. AVAILABILITY $\mathrm{x}$ Unlınited & $\begin{array}{l}\text { 19. SECUR!TY CLASS } \\
\text { (THIS REPORT) }\end{array}$ & $\begin{array}{l}\text { 21. NO. OF } \\
\text { PIRINTED PAGLS }\end{array}$ \\
\hline I : For Otficial Distribution. Do Wot Release to NTIS & UNCLASSIFIEED & 79 \\
\hline $\begin{array}{l}\text { Order From Sup. of Doc., U.S. Government Prunting Office, Wasinngton, DC } \\
20402 \text {, SD Stock No. SN003-003- }\end{array}$ & $\begin{array}{l}\text { 20. SECURITY CLASS } \\
\text { (THIS PAGE) }\end{array}$ & 2?. Price \\
\hline $\begin{array}{l}\text { X. O,deı From National Technical Iıformation Service (NTIS), Sprıngfıeld, } \\
\text { VA. } 22161\end{array}$ & UNCLASSIFIED & $\$ 8.00$ \\
\hline
\end{tabular}



